\title{
Potential of Flow Cytometric Approaches for Rapid Microbial Detection and Characterization in the Food Industry-A Review
}

\author{
Elena Zand ${ }^{1,+(\mathbb{D}}$, Antje Froehling ${ }^{2,+}$, Christoph Schoenher ${ }^{3}$, Marija Zunabovic-Pichler ${ }^{3}$, Oliver Schlueter $^{2} \mathbb{D}$ and \\ Henry Jaeger ${ }^{1, *}$ \\ 1 Department of Food Science and Technology, Institute of Food Technology, University of Natural Resources \\ and Life Sciences Vienna (BOKU), 1190 Vienna, Austria; elena.zand@boku.ac.at \\ 2 Leibniz Institute for Agricultural Engineering and Bioeconomy, Quality and Safety of Food and Feed, \\ 14469 Potsdam, Germany; afroehling@atb-potsdam.de (A.F.); oschlueter@atb-potsdam.de (O.S.) \\ 3 Institute of Sanitary Engineering and Water Pollution Control, University of Natural Resources and Life \\ Sciences, 1190 Vienna, Austria; christoph.schoenher@boku.ac.at (C.S.); marija.zunabovic@boku.ac.at (M.Z.-P.) \\ * Correspondence: henry.jaeger@boku.ac.at \\ + These authors contributed equally to this work.
}

check for updates

Citation: Zand, E.; Froehling, A.; Schoenher, C.; Zunabovic-Pichler, M.; Schlueter, O.; Jaeger, H. Potential of Flow Cytometric Approaches for Rapid Microbial Detection and Characterization in the Food Industry-A Review. Foods 2021, 10, 3112. https://doi.org/10.3390/ foods10123112

Academic Editors: Walter Randazzo and Pilar Truchado

Received: 7 October 2021

Accepted: 16 November 2021

Published: 15 December 2021

Publisher's Note: MDPI stays neutra with regard to jurisdictional claims in published maps and institutional affiliations.

Copyright: (C) 2021 by the authors Licensee MDPI, Basel, Switzerland This article is an open access article distributed under the terms and conditions of the Creative Commons Attribution (CC BY) license (https:// creativecommons.org/licenses/by/ $4.0 /)$

\begin{abstract}
As microbial contamination is persistent within the food and bioindustries and foodborne infections are still a significant cause of death, the detection, monitoring, and characterization of pathogens and spoilage microorganisms are of great importance. However, the current methods do not meet all relevant criteria. They either show (i) inadequate sensitivity, rapidity, and effectiveness; (ii) a high workload and time requirement; or (iii) difficulties in differentiating between viable and non-viable cells. Flow cytometry (FCM) represents an approach to overcome such limitations. Thus, this comprehensive literature review focuses on the potential of FCM and fluorescence in situ hybridization (FISH) for food and bioindustry applications. First, the principles of FCM and FISH and basic staining methods are discussed, and critical areas for microbial contamination, including abiotic and biotic surfaces, water, and air, are characterized. State-of-the-art non-specific FCM and specific FISH approaches are described, and their limitations are highlighted. One such limitation is the use of toxic and mutagenic fluorochromes and probes. Alternative staining and hybridization approaches are presented, along with other strategies to overcome the current challenges. Further research needs are outlined in order to make FCM and FISH even more suitable monitoring and detection tools for food quality and safety and environmental and clinical approaches.
\end{abstract}

Keywords: flow cytometry; fluorescence in situ hybridization; inline monitoring; microbial contamination; food safety

\section{Introduction}

Microbial contamination, including the carryover of infectious microbes, is a global public health concern [1]. Food and beverage production and medical areas, including hospitals and pharmaceutical manufacturing, are of particular concern. Although clean rooms and sterile air filtration techniques are standard within medical areas, their use in the food industry is limited, mainly due to high construction and maintenance costs and the non-sterile conditions in production plants. Consequently, the increased persistence of microbes within food areas has been observed, even though hygiene standards have been massively increased nowadays with the implementation of HACCP, GMP, and GHP [2-4]. Microbial resistance against extrinsic factors is related to their fast adaptability and the formation of microbial biofilms, which can protect spoilage microorganisms and bacterial pathogens from chemical and physical actions [2,3,5,6]. Frequently detected pathogens include Salmonella spp., Listeria monocytogenes, Escherichia coli, Shigella spp., Vibrio spp., Campylobacter jejuni, and Yersinia spp., whereas frequent spoilage microorganisms are, for instance, Acinetobacter spp., Pseudomonas spp. or Botrytis spp. [7-10]. According to the 
WHO [11], 600 million foodborne infections in 2010, from which 420,000 people died, were associated with bacterial pathogens. Furthermore, the number of unreported foodborne diseases is outstandingly high [11].

Effective qualitative and quantitative monitoring and detection tools are required to minimize the contamination risk. The gold standard among detection tools is still the conventional plating method, with its high sensitivity and selectivity $[12,13]$. However, plating is time-consuming, labor-intensive, and detects only viable and cultivable microbes [7,14]. Complementarily, there are several rapid and culture-independent approaches that overcome these limitations of plating. Among the most widely-known detection methods are molecular methods such as polymerase chain reaction (PCR) or enzyme-linked immunosorbent assay (ELISA) methods $[7,13,15,16]$. Some molecular methods are vulnerable to interference from inhibitory compounds (i.e., the lipid content) or can affect complex matrices such as food. For highly sensitive methods such as PCR, contamination can easily lead to false results. In addition, PCR may be unable to distinguish between viable and non-viable cells $[13,17]$.

An alternative technique that serves as a powerful, rapid, and highly sensitive $[13,18]$ method for the specific and non-specific detection, monitoring, enumeration, and characterization of microorganisms is flow cytometry (FCM). FCM allows a culture-independent quantitative count of microbial cells. In addition, flow cytometry provides information on the physiological and structural characteristics of microbial cells and their viability and can therefore be used as an additional characterization tool. Rapid and reliable detection, quantification and characterization of foodborne pathogens are of great interest to the food industry in order to minimize foodborne diseases [19]. The rapid techniques used to detect foodborne pathogens can be categorized into immunological, biosensor, and nucleic acid-based methods [20]. Fluorescence in situ hybridization (FISH) is a nucleic acid-based method and is mainly applied in the medical and diagnostic field [19].

Even though current rapid detection approaches such as PCR or ELISA overcome the limitations of culture-based techniques, they do not meet all the criteria required, including effectiveness, reproducibility, rapidity, and sensitivity [13]. This review, therefore, provides detailed information on currently developed FCM and Flow-FISH protocols for the non-specific and specific detection, monitoring, and characterization of microbial contamination.

\section{Microbial Habitats and Detection Targets within the Food Industry and Bioindustry}

For the efficient and rapid detection of microbial contaminants, potential microbial habitats need to be considered in order to adapt detection tools such as FCM and the preceding sampling procedures. Generally, water, air and abiotic as well as biotic surfaces are parts of microbial contamination routes.

\subsection{Water}

Water is indispensable within the food and bioindustry for processing or washing steps and cleaning equipment and (non-) food contact surfaces. Wastewater can be either re-used or drained off $[21,22]$. Water monitoring was previously proposed as an alternative for pathogen detection within the food industry $[23,24]$. For example, drain water was proposed to be less biased than small-area swabs and is often linked to drain biofilms [24]. As a result, the drain water itself and the drain biofilm matrix are crucial for detecting microbial communities [22]. Any stagnant water, such as floor drains, can turn into a contamination source, further re-contaminating food or other products via spray water or aerosols [25].

\subsection{Air and Aerosols}

The air is a potential source and distributor of microbes within the processing areas [26]. Aerosols are often related to cleaning operations but can also originate from people, rotating equipment, or raw materials [4]. Air-borne contamination usually depends 
on the microbial load within the air and the exposure time between the product and the air, i.e., during sedimentation. In addition to sedimentation, air particles can also interact with the product or surface through cooling or heating procedures [26]. There are multiple approaches for reducing or preventing air-borne contamination, including appropriate air exchange rates and filtration technologies, maintaining positive pressure in critical areas, high pressure near doorways or other openings, and restraining airflow out of non-critical areas [4]. These ventilation-based tools are easily applied within clean rooms; however, their use within significant production areas is not always practicable.

\subsection{Abiotic and Biotic Surfaces}

Adherent microbes are found on all kinds of abiotic surfaces, including conveyor belts, stainless steel or polymer surfaces, gaskets, floors, and walls, as well as process units within the food and bioindustry, as well as medical devices [27-29]. These interactions between microbes and abiotic surfaces are accompanied mainly by biofilm growth [30,31] and the biofilm-forming ability is generally affected by the physicochemical and topographical properties of the respective food contact surfaces [32]. Other natural habitats for microbes are biotic surfaces, including fresh and/or raw food products such as meat, sprouted seeds, vegetables, or salad. For plant-based products, contamination can already take place during crop growth through the soil, water, or the use of fertilizers [21,33]. Most crosscontamination, however, occurs during process steps from a contact surface to the product, such as after the slicing of meat [5]. As the microbial safety of fresh food products is an emerging public health concern, alternative preventive methods for detecting pathogens and spoilage microorganisms, instead of end-product analysis, are required [34,35].

Due to the frequent occurrence of biofilms and their high relevance as hygiene and safety concerns, detection and avoidance are of the utmost importance. In this regard, rapid detection tools need to be applied to allow real-time process monitoring. For this purpose, innovative rapid and preventive control strategies are necessary. FCM and Flow-FISH are promising tools for online and inline detection and monitoring of microbial contamination from water, air, and abiotic (i.e., conveyor belts or pipelines) and biotic surfaces (i.e., solid food samples). The currently available FCM and Flow-FISH applications for detecting and monitoring water, air, and food matrices are discussed in the following two sections.

\section{Non-Specific State-of-the-Art Flow Cytometric Applications for Detection and Monitoring}

\subsection{FCM Principle and Detection Mechanisms}

In principle, FCM allows the analysis of the chemical and physical characteristics of any suspended single particle. The optical system of an FCM is illustrated in Figure 1. Usually, it contains the following: a flow chamber, a source of light (i.e., a laser or mercury lamp), dichroic mirrors to bring the light beam into focus, bandpass filters for the detection of different wavelengths, detectors (i.e., photodiodes (PD) and photomultiplier tubes (PMT)) for the detection and amplification of the signals, as well as a data processing unit [36-39]. After transferring the particles into a laminar flow of sheath fluid, scattered light and fluorescence signals are utilized one by one at the interrogation point of the laser beam. To differentiate cells regarding their morphology (i.e., particle size or granularity), forward- (FSC) or side-scattered light (SSC) is detected, respectively. Aside from scattered light, fluorescence appears when fluorochromes or particles labeled with them emit light, which is then excited by a beam of an appropriate wavelength. Some cells can emit fluorescence without fluorochromes, which is called autofluorescence. This phenomenon can be either beneficial for analysis or can impede other fluorescence signals. Most of the time, autofluorescence alone is not sufficient to detect and distinguish between cell populations. Thus, FCM protocols include a staining step with one or more fluorescent dyes before sample analysis [17,40]. 


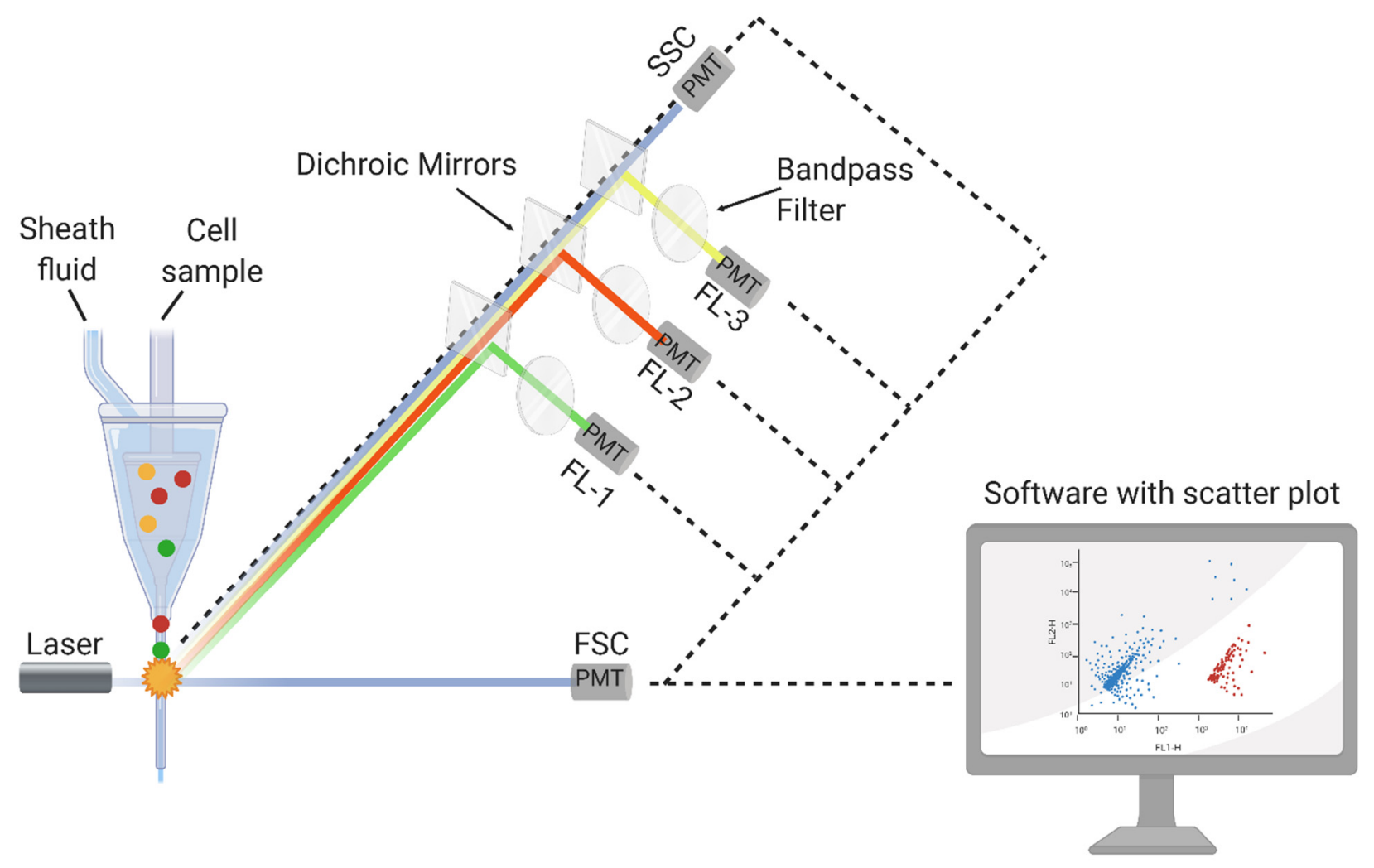

Figure 1. Principle of a flow cytometer (FCM). Forward-scattered light (FSC); side-scattered light (SSC); photomultiplier tubes (PMT, fluorescence detectors); detectors at a specific wavelength (FL-1, FL-2, and FL-3); (made in CBioRenderbiorender.com, Toronto, ON, Canada (accessed on 8 June 2021)).

Depending on the FCM protocol, various quantitative data can be obtained, including cell vitality, viability, or rather the physiological status and the stage of the growth cycle [18]. For the analysis of physiological status, fluorescent dyes, or rather fluorochromes, can target enzymatic activity, membrane integrity, pump activity, or membrane potential [41]. Dyes that intercalate with double-stranded nucleic acids are often used to assess the nucleic acid content, total cell count, or cell viability based on the cell membrane integrity [42]. For the latter, a combination of a permeant (i.e., Hoechst dyes, dyes from the SYTO- or SYBR-family, thiazole orange (TO)), and an impermeant dye (i.e., ethidium bromide (EtBr) or propidium iodide (PI)) is used. Moreover, the electrochemical membrane potential is another target for the testing of cell viability. Here, cationic dyes (i.e., 3,3'-Diethyloxacarbocyanine Iodide $\left.\left(\mathrm{DiOC}_{2}(3)\right)\right)$ accumulate in polarized cells and anionic dyes (i.e., Bis-(1,3-Dibutylbarbituric Acid)Trimethine Oxonol or rhodamine $123\left(\right.$ DiBA-C $\left._{4}(3)\right)$ amass in depolarized cells, consequently emitting different fluorescent signals for viable and non-viable cells [43]. Changes in membrane composition can be measured by the extension of fluidity with 1,6-Diphenyl1,3,5-hexatriene (DPH), indicating changes in the physiological state. Esterase activity or dehydrogenase activity, both being enzymatic mechanisms, are suitable for detecting, e.g., endospore viability or sublethally injured cells [44,45]. Respiratory activity is typically examined by loading cells with permeant nonfluorescent stains such as tetrazolium dyes, which are then converted to fluorescent substances by dehydrogenases. The most popular one is 5-cyano-2,3-ditolyl tetrazolium chloride (CTC), which is converted into the impermeant red molecule formazan [45]. For esterase activity assessments, fluorescin diacetate (FDA), carboxyfluorescein diacetate (cFDA), or acetoxymethyl ester (calcein-AM) are frequently used [46,47]. Another method for viability testing is the pump activity, in which the dye (i.e., ethidium bromide, rhodamine 123) loaded into the cells is again pumped out of the cells, increasing the fluorescent signal [48]. Moreover, changes in the intracellular $\mathrm{pH}$ can also be evaluated, with specific dyes that change their fluorescent 
signal depending on the $\mathrm{pH}$ value. Intracellular $\mathrm{pH}$ is a good target when assessing external effects on bacterial cells [46]. Furthermore, physical or structural parameters are also assessable. Gram staining, for instance, is rapidly performed with two fluorescent dyes, namely, hexidium iodine and oregon green, targeting Gram-negative and Gram-positive cells, respectively.

A quantitative FCM analysis can also provide qualitative data, such as specific cell clusters. Therefore, it can be further used to characterize microbial communities. FCM techniques, such as fingerprinting methods, can enhance the derivation of qualitative information [49]. With so-called fluorescence-activated cell sorters (FACS), single cells or subpopulations are sorted from a mixed population based on one or more specific characteristics and can be used for further analysis or growth [50]. Furthermore, specific targets such as food pathogens [51], infectious bacteria [52], and environmental contaminants are easily detected by FCM combined with phylogenetic labeling. Flow-FISH is a phylogenetic labeling method in which specific nucleic acid sequences inside intact viable cells are labeled [53], as further discussed in Section 4.

\subsection{Food-Related FCM Applications}

For food-related research, FCM is mainly used for the performance testing of food preservation or disinfection approaches, i.e., sodium hypochlorite or peracetic acid disinfection, ultraviolet light (UV-C), supercritical $\mathrm{CO}_{2}$ pasteurization, ohmic heating applications, non-thermal inactivation technologies, including pulsed electric fields and cold atmospheric pressure plasma treatment, as well as natural preservatives such as essential oils $[47,54-62]$. The most commonly investigated microorganism was E. coli [3,55-57,59-61,63-66].

A study by Coronel-Leon et al. [67] tested the antimicrobial effect of the surfactant $\mathrm{N}^{\alpha}$-lauroyl L arginine ethylester monohydrochloride as a food additive and used FCM to understand the inactivation mechanisms better and to indicate the presence of sublethally injured cells. The most popular cell target for viability staining is membrane integrity, in which DNA-intercalating dyes are applied. Moreover, esterase activity is a suitable detection target, as potential sublethal injured cells after inefficient inactivation procedures are observed. For this purpose, FDA or cFDA are combined with PI [44,59]. Tamburini et al. [60] concluded that FCM was the most suitable viability assessment method compared to PCR, plate counts, and fluorescence microscopy.

FCM is not only a suitable tool for detecting sublethally injured cells but also for cells in the viable but non-culturable (VBNC) state. This is important as environmental stresses present during food processes, such as temperature change, $\mathrm{pH}$, or the absence of nutrients, can introduce cells into the VBNC state. With culture-based techniques, only viable and culturable cells are detected. VBNC cells, however, are able to resuscitate and become culturable again [68]. Thus, FCM viability staining, in combination with plate count, can be conducted to detect the VBNC state of cells. Khan et al. [64] optimized staining protocols for VBNC enumeration by eliminating the interference with other particles and optimized the cell concentration to $10^{4}$ cells $\mathrm{mL}^{-1}$. Another study by Yu et al. [66] increased the sensitivity. It significantly reduced the background signals of impurity particles with the use of a high-sensitivity flow cytometer to detect microbes within the VBNC state. Comprehensive information about the role of sublethally injured cells and cells within the VBNC state on food safety matters is summarized in a review by Schottroff et al. [69].

Moreover, bacterial counts and viability in fermented products, including wine or probiotic products, were previously monitored with FCM. For wine samples, the viability and growth dynamics of yeasts and bacteria were measured, but prior washing steps had to be included to eliminate interference from other particles [70]. With the stain ChemChrome, viability assessment was possible even while natural particles were present in the sample [71]. According to Bunthof and Abee [72], FCM is highly sensitive and more accurate than plate counts.

Most of the available food-related studies use FCM for liquid samples, including juice, tea, water, wine, probiotic products, and milk, just to name a few. Fröhling, Durek, 
et al. [73] used FCM to evaluate indirect plasma treatment of fresh pork meat. Within their study, the meat samples were homogenized and centrifuged to remove the remaining meat debris (Table 1). For viability analysis of remaining bacterial cells after plasma treatment, cFDA and PI staining was successfully conducted. In another study, Juzwa et al. [3] applied a combination of FCM and cell sorting to improve microbial strain isolation from stainless steel surfaces within a fruit and vegetable processing company. Surfaces were swabbed with sterile cotton swabs and immediately resuspended in buffer solution for further FCM analysis.

Table 1. State of the art FCM applications in liquid and solid food matrices, as well as abiotic surfaces.

\begin{tabular}{|c|c|c|c|c|}
\hline $\begin{array}{l}\text { Research Area/ } \\
\text { Food Matrix }\end{array}$ & $\begin{array}{l}\text { Model Microorganism/ } \\
\text { Sample Type/ } \\
\text { Sample Location }\end{array}$ & $\begin{array}{c}\text { Detection Target, } \\
\text { Fluorochrome(s), and Gating }\end{array}$ & $\begin{array}{l}\text { Sample Preparation and } \\
\text { Observation Methods }\end{array}$ & References \\
\hline Wine & $\begin{array}{c}\text { Yeasts (Saccharomyces } \\
\text { cerevisiae and } \\
\text { Saccharomyces bayanus } \\
\text { strains) } \\
\text { Malolactic bacteria } \\
\text { (Oenococcus oeni strains); } \\
\text { Fresh wine samples from } \\
\text { different wineries }\end{array}$ & $\begin{array}{l}\text { Viability (Rhodamine 123, } \\
\text { calcein acetoxymethyl ester, } 2 ", \\
\text { 7"'-bis(carboxyethyl)-5(6)- } \\
\text { carboxyfluorescein } \\
\text { acetoxymethyl ester, } \\
\text { fluorescein diacetate (FDA)) }\end{array}$ & $\begin{array}{l}\text { Samples were diluted, centrifuged } \\
\text { and suspended in PBS } \\
\text { Incubation ( } 5 \text { min for yeasts and } \\
15 \text { min for malolactic bacteria cells) } \\
\text { FCM and CFU enumeration }\end{array}$ & [70] \\
\hline $\begin{array}{l}\text { Milk, fermentation starters } \\
\text { and probiotic products }\end{array}$ & $\begin{array}{c}\text { Lactiplantibacillus } \\
\text { plantarum WCFS } 1 \text { for milk } \\
\text { samples } \\
\text { Commercially available } \\
\text { diary starters (mixed } \\
\text { cultures) } \\
\text { Probiotic products (mixed } \\
\text { cultures) }\end{array}$ & $\begin{array}{c}\text { TCC (SYTO 9) } \\
\text { Viability, based on enzymatic } \\
\text { activity and } \\
\text { membrane-permeabilized cells } \\
\text { (carboxyfluorescein diacetate } \\
\text { (cFDA) and TOTO-1) }\end{array}$ & $\begin{array}{c}\text { Milk samples: L. plantarum } \\
\text { samples within the exponential } \\
\text { growth phase were resuspended in } \\
\text { semi-skimmed pasteurized milk } \\
\text { and cleared } \\
\text { The cheese starter was analyzed } \\
\text { directly and after incubation } \\
\text { Yogurt starters were analyzed } \\
\text { without any further preparation } \\
\text { Probiotic products (Yakult, } \\
\text { Orthiflorplus, Mona Vifit yogurt } \\
\text { drink) were cleared before } \\
\text { sampling } \\
\text { Total assay time (1 h) } \\
\text { FCM compared to CFU } \\
\text { enumeration and fluorescence } \\
\text { microscopy }\end{array}$ & [72] \\
\hline $\begin{array}{c}\text { Non-dairy probiotic } \\
\text { drinks and } \\
\text { pharmaceutical products }\end{array}$ & $\begin{array}{c}\text { Pure cultures: four } \\
\text { different Lactobacillus } \\
\text { strains and Bifidobacterium } \\
\text { animalis subsp. lactis } \\
\text { Two commercially } \\
\text { available pharmaceutical } \\
\text { probiotic products and six } \\
\text { probiotic drinks }\end{array}$ & $\begin{array}{c}\text { Intracellular enzymatic } \\
\text { reaction and intact cell } \\
\text { membrane } \\
\text { (ChemChrome, cFDA, } \\
\text { cFDA-AM, sFDA, and CAM) } \\
\text { Viability (SYTO 9 and } \\
\text { propidium iodide (PI)) }\end{array}$ & $\begin{array}{l}\text { Samples were suspended in either } \\
\text { ringer solution or PBS } \\
\text { Incubation with ChemChrome } \\
\text { (10 min), with other esterase } \\
\text { activity dyes (15-60 min) } \\
\text { FCM, fluorescence microscopy and } \\
\text { fluorometer }\end{array}$ & [71] \\
\hline $\begin{array}{c}\text { Pulsed electric field (PEF) } \\
\text { inactivation } \\
\text { Milk }\end{array}$ & $\begin{array}{l}\text { Lactobacillus rhamnosus } \\
\text { E522 }\end{array}$ & $\begin{array}{l}\text { Esterase activity and } \\
\text { membrane integrity (cFDA } \\
\text { and PI) }\end{array}$ & $\begin{array}{c}\text { PEF-treated samples were } \\
\text { centrifuged }(2600 \times g, 10 \mathrm{~min}), \\
\text { resuspension in } 50 \mathrm{mM} \text { PBS } \\
\text { Incubation }\left(10 \mathrm{~min}, 37^{\circ} \mathrm{C}, \mathrm{cFDA}\right), \\
\text { washing to remove excessive } \\
\text { cFDA, incubation }(10 \mathrm{~min} \text {, on } \\
\text { ice, PI) } \\
\text { FCM and colony count }\end{array}$ & [58] \\
\hline $\begin{array}{l}\text { Detection of VBNC for } \\
\text { increased microbiological } \\
\text { safety }\end{array}$ & $\begin{array}{l}\text { P. aeruginosa } \\
\text { Pseudomonas syringae } \\
\text { S. Typhimurium } \\
\text { E. coli } \text { O157:H7 }\end{array}$ & $\begin{array}{c}\text { TCC, viability, and VBNC } \\
\text { (SYTO 9, SYTO 13, SYTO 17, or } \\
\text { SYTO } 40 \text { in combination } \\
\text { with PI) }\end{array}$ & $\begin{array}{l}\text { Strains were used at the late log } \\
\text { phase in either King's broth or } \\
\text { Luria-Bertani broth (and } \\
\left.\text { heat-treated at } 72^{\circ} \mathrm{C} \text { for } 5-15 \mathrm{~min}\right) \\
\text { Total assay time }(70 \mathrm{~min}), \\
\text { incubation }(60 \mathrm{~min}) \\
\text { FCM and CFU enumeration }\end{array}$ & [64]) \\
\hline
\end{tabular}


Table 1. Cont.

\begin{tabular}{|c|c|c|c|c|}
\hline $\begin{array}{l}\text { Research Area/ } \\
\text { Food Matrix }\end{array}$ & $\begin{array}{l}\text { Model Microorganism/ } \\
\text { Sample Type/ } \\
\text { Sample Location }\end{array}$ & $\begin{array}{l}\text { Detection Target, } \\
\text { Fluorochrome(s), and Gating }\end{array}$ & $\begin{array}{l}\text { Sample Preparation and } \\
\text { Observation Methods }\end{array}$ & References \\
\hline $\begin{array}{l}\text { Disinfection efficiency and } \\
\text { Mastitis detection } \\
\text { Milk }\end{array}$ & E. coli DSM 1116 & $\begin{array}{c}\text { Cell membrane integrity } \\
\text { (Thiazole orange }(\mathrm{TO}) \text { and } \mathrm{PI}) \\
\text { Metabolic activity and } \\
\text { membrane integrity } \\
\text { (cFDA + PI) } \\
\text { Cell membrane potential } \\
\left(3,3^{\prime} \text {-diethyloxacarbocyanine }\right. \\
\text { iodide }\left(\mathrm{DiOC}_{2}(3)\right)\end{array}$ & $\begin{array}{c}\text { E. coli was analyzed at stationary } \\
\text { phase in PBS (pH 7.0) } \\
\text { Incubation (TO + PI, } 10 \mathrm{~min} ; \\
\text { cFDA + PI, } 45 \mathrm{~min} ; \mathrm{DiOC}_{2}(3) \\
15 \text { min) } \\
\text { FCM, coulter counter and CFU } \\
\text { enumeration }\end{array}$ & [57] \\
\hline Food preservation & $\begin{array}{l}\text { E. coli ATCC } 11229 \\
\text { L. innocua ATCC } 33090 \\
\text { S. cerevisiae KE162 }\end{array}$ & $\begin{array}{l}\text { Membrane integrity (PI) and } \\
\text { esterase activity (fluorescein } \\
\text { diacetate (FDA)) }\end{array}$ & $\begin{array}{l}\text { Strains were analyzed at the } \\
\text { stationary phase in PBS buffer } \\
\text { (pH 7.0) } \\
\text { Incubation (PI, } 10 \text { min; FDA, } \\
30 \text { min) } \\
\text { FCM and CFU enumeration }\end{array}$ & [59] \\
\hline $\begin{array}{l}\text { Indirect plasma treatment } \\
\text { Fresh pork }\end{array}$ & $\begin{array}{l}\text { Fresh pork (directly from } \\
\text { the slaughterhouse) }\end{array}$ & $\begin{array}{l}\text { Viability based on esterase } \\
\text { activity and membrane } \\
\text { integrity (cFDA and PI) }\end{array}$ & $\begin{array}{l}\text { After plasma treatment of meat } \\
\text { samples } \\
\text { Homogenization of meat samples } \\
\text { and centrifugation }\left(200 \times g, 4^{\circ} \mathrm{C} \text {, }\right. \\
2 \text { min) to remove meat particles } \\
\text { Centrifugation of supernatant } \\
\left(4000 \times g, 4^{\circ} \mathrm{C}, 6 \mathrm{~min}\right) \\
\text { Re-suspension (in } 0.05 \mathrm{M} \mathrm{PBS}) \\
\text { Incubation }(15 \mathrm{~min}, 37 \mathrm{C}) \\
\text { FCM, fluorescence spectrometer, } \\
\mathrm{UV} / \text { Vis/NIR spectrophotometer, } \\
\text { and colony count }\end{array}$ & [73] \\
\hline $\begin{array}{l}\text { Non-thermal plasma } \\
\text { treatment } \\
\text { Bacterial model system on } \\
\text { polysaccharide gels }\end{array}$ & $\begin{array}{l}\text { L. innосиа DSM } 20649 \\
\text { E. coli DSM } 1116\end{array}$ & $\begin{array}{c}\text { Esterase activity (cFDA) } \\
\text { Membrane integrity and RNA } \\
\text { and DNA damage (TO and PI) }\end{array}$ & $\begin{array}{l}\text { Gelrite }{ }^{\circledR} \text { polysaccharide gels were } \\
\text { inoculated with } 25 \mu \mathrm{L} \text { bacteria } \\
\text { suspension } \\
\text { After plasma treatment, bacteria } \\
\text { were resuspended in } 0.05 \mathrm{M} \text { PBS } \\
\text { and agitated ( } 5 \mathrm{~min}, 750 \mathrm{rpm} \text {, } \\
\left.\qquad 37^{\circ} \mathrm{C}\right) \\
\text { Incubation }(15 \mathrm{~min}+10 \mathrm{~min} \text { for } L . \\
\text { innocua and } 45 \mathrm{~min}+10 \mathrm{~min} \text { for } E \text {. } \\
\text { coli, cFDA and PI; } 10 \mathrm{~min}, \mathrm{TO}+\mathrm{PI}) \\
\text { After cFDA and PI staining, } \\
\text { centrifugation }(4000 \times g, 6 \mathrm{~min}, \\
\left.4^{\circ} \mathrm{C}\right) \text { to remove cFDA } \\
\text { FCM and colony count }\end{array}$ & [56] \\
\hline $\begin{array}{l}\text { Fresh food preservation } \\
\text { and analytical viability } \\
\text { methods }\end{array}$ & $\begin{array}{l}\text { L. monocytogenes } \\
\text { E. coli } \\
\text { Salmonella enterica }\end{array}$ & $\begin{array}{c}\text { Viability SYBR }{ }^{\circledR} \text { Green I (SG1) } \\
\text { and PI) }\end{array}$ & $\begin{array}{c}\text { In vitro experiment: type cultures } \\
\text { were incubated until stationary } \\
\text { phase }(16 \mathrm{~h}) \\
\text { Incubation }(15 \mathrm{~min}) \\
\text { FCM vs. propidium monoazide } \\
\text { quantitative PCR } \\
\text { Reference methods: CFU } \\
\text { enumeration and fluorescence } \\
\text { microscopy }\end{array}$ & [60] \\
\hline Drinking water and tea & E. coli ER2738 & $\begin{array}{c}\text { TCC, viability and VBNC state } \\
\text { (PicoGreen, for tea samples: } \\
+1 \text { mM EDTA }{ }^{2} \text { ) } \\
\text { Gating with FSC and SSC }\end{array}$ & $\begin{array}{l}\text { E. coli cells were used in stationary } \\
\text { phase and spiked to either water } \\
\text { or jasmine green tea sample } \\
\text { Assay time }(<20 \mathrm{~min}) \\
\text { New FCM approach and CFU } \\
\text { enumeration }\end{array}$ & [66] \\
\hline
\end{tabular}


Table 1. Cont.

\begin{tabular}{|c|c|c|c|c|}
\hline $\begin{array}{l}\text { Research Area/ } \\
\text { Food Matrix }\end{array}$ & $\begin{array}{l}\text { Model Microorganism/ } \\
\text { Sample Type/ } \\
\text { Sample Location }\end{array}$ & $\begin{array}{l}\text { Detection Target, } \\
\text { Fluorochrome(s), and Gating }\end{array}$ & $\begin{array}{l}\text { Sample Preparation and } \\
\text { Observation Methods }\end{array}$ & References \\
\hline $\begin{array}{c}\text { New inactivation } \\
\text { technologies (peracetic } \\
\text { acid, ozonated water, cold } \\
\text { atmospheric pressure } \\
\text { plasma) } \\
\text { Fruits and vegetables }\end{array}$ & $\begin{array}{c}\text { E. coli DSM } 1116 \\
\text { L. innocua DSM } 20649 \\
\text { Pectobacterium carotovorum } \\
\text { spp. carotovorum DSM } \\
\quad 30168\end{array}$ & $\begin{array}{l}\text { Membrane integrity and } \\
\text { RNA/DNA damage (TO } \\
\text { and PI) } \\
\text { Esterase activity (cFDA) } \\
\text { Membrane potential } \\
\left(\operatorname{DiOC}_{2}(3)\right)\end{array}$ & $\begin{array}{l}\text { Treated samples were centrifuged } \\
\left(3220 \times g \text { for } 15 \mathrm{~min}, 4^{\circ} \mathrm{C}\right) \text { and } \\
\text { resuspended in } 50 \mathrm{mM} \text { PBS or } \\
\text { directly resuspended in PBS and } \\
\text { agitated }\left(5 \mathrm{~min}, 750 \mathrm{rpm}, 37^{\circ} \mathrm{C}\right) \\
\text { Incubation }(10 \mathrm{~min}, \mathrm{TO}+\mathrm{PI} \text {; } \\
15 \text { min, DiOC } 2(3) ; 15 \text { or } 45 \text { min for } \\
\text { Gram-positive or Gram-negative } \\
\text { bacteria, respectively, cFDA) } \\
\text { FCM and colony count }\end{array}$ & [63] \\
\hline $\begin{array}{l}\text { Antimicrobial surfactant } \\
\text { and food safety }\end{array}$ & $\begin{array}{l}\text { Yersinia enterocolitica ATCC } \\
\qquad 9610 \\
\text { L. plantarum ATCC } 8014\end{array}$ & $\begin{array}{l}\text { Viability (PI and bis-oxonol) } \\
\text { The cell population was } \\
\text { selected via gating of FSC vs. } \\
\text { SSC } \\
\text { Aggregates and cell debris } \\
\text { were excluded }\end{array}$ & $\begin{array}{l}\text { After treatment, strains were } \\
\text { diluted in filtered buffered peptone } \\
\text { water and stains were added } \\
\text { Incubation (n.a. }{ }^{1} \text { ) } \\
\text { FCM and transmission electron } \\
\text { microscopy }\end{array}$ & [67] \\
\hline Juice preservation & S. cerevisiae KE 162 & $\begin{array}{l}\text { Viability, esterase activity, and } \\
\text { membrane integrity (FDA } \\
\text { and PI) }\end{array}$ & $\begin{array}{l}\text { S. cerevisiae cells were analyzed in } \\
\text { either peptone water or } \\
\text { carrot-orange juice } \\
\text { Incubation ( } 30 \text { min, FDA; } \\
10 \text { min, PI) } \\
\text { FCM, TEM and CFU enumeration }\end{array}$ & [44] \\
\hline $\begin{array}{l}\text { Essential oils against } \\
\text { foodborne pathogens }\end{array}$ & $\begin{array}{l}\text { L. monocytogenes Scott A } \\
\text { E. coli MG } 1655\end{array}$ & $\begin{array}{c}\text { Membrane integrity (TO } \\
\text { and PI) } \\
\text { Cell membrane potential } \\
\left(\mathrm{DiOC}_{2}(3)\right) \\
\text { Viability based on cell } \\
\text { membrane integrity and } \\
\text { esterase activity (cFDA and PI) }\end{array}$ & $\begin{array}{c}\text { After treatment, bacterial cells } \\
\text { were centrifuged }\left(7000 \times g, 4^{\circ} \mathrm{C} \text {, }\right. \\
15 \mathrm{~min}) \text {, resuspended in } 50 \mathrm{mM} \\
\text { PBS, and centrifuged }(7000 \times g \\
\left.4^{\circ} \mathrm{C}, 5 \mathrm{~min}\right) \\
\text { Incubation }(10-15 \mathrm{~min}, \mathrm{TO} ; \\
5 \mathrm{~min}, \mathrm{PI} ; 45 \mathrm{~min}, \mathrm{cFDA} \text {, and PI; } \\
\left.15 \text { min, } \mathrm{DiOC}_{2}(3)\right) \\
\text { FCM and colony count }\end{array}$ & [55] \\
\hline Food-borne pathogens & Staphylococcus aureus & $\begin{array}{c}\text { Viability } \\
\text { (SYTO 9 and PI } \\
\text { Cyanide } \\
\text { 3-chlorophenylhydrazone } \\
\text { (CCCP) and DiOC } 2 \\
\text { Calcein-AM, PI and } \\
\text { cetyltrimethyl ammonium } \\
\text { bromide (CTAB)) }\end{array}$ & $\begin{array}{c}\text { Cultures were cultivated in } \\
\text { nutrient broth until exponential } \\
\text { phase } \\
\text { Incubation ( } 30 \text { min, calcein-AM; } \\
15 \text { min, other dyes) } \\
\text { FCM and scanning electron } \\
\text { microscopy }\end{array}$ & [53] \\
\hline Lettuce disinfection & E. coli CECT 434 & Viability (SYTO-BC and PI) & $\begin{array}{c}\text { Inoculated and disinfected lettuce } \\
\text { samples were suspended and } \\
\text { stirred } \\
\text { in } 0.9 \% \mathrm{NaCl} \text {, from what } 2 \mathrm{~mL} \\
\text { were } \\
\text { removed for FCM and } 200 \mu \mathrm{L} \\
\text { for CFU } \\
\text { enumeration } \\
\text { Incubation (10 min) } \\
\text { FCM and CFU enumeration }\end{array}$ & [61] \\
\hline Microbial egg safety & $\begin{array}{l}\text { Eggs spiked with } \\
\text { pathogenic Salmonella } \\
\text { Typhimurium and } \\
\text { harmless E. coli } \mathrm{K} 12\end{array}$ & TCC & $\begin{array}{l}\text { E. coli strain, clay, PBS, and } \\
\text { fluorochromes were mixed at fixed } \\
\text { volumes to a sample mixture } \\
\text { Total assay time }(1.5 \mathrm{~h}) \\
\text { FCM and settling method }\end{array}$ & [65] \\
\hline
\end{tabular}


Table 1. Cont

\begin{tabular}{|c|c|c|c|c|}
\hline $\begin{array}{l}\text { Research Area/ } \\
\text { Food Matrix }\end{array}$ & $\begin{array}{l}\text { Model Microorganism/ } \\
\text { Sample Type/ } \\
\text { Sample Location }\end{array}$ & $\begin{array}{c}\text { Detection Target, } \\
\text { Fluorochrome(s), and Gating }\end{array}$ & $\begin{array}{l}\text { Sample Preparation and } \\
\text { Observation Methods }\end{array}$ & References \\
\hline $\begin{array}{l}\text { Ohmic heating } \\
\text { Paraprobiotics production }\end{array}$ & $\begin{array}{l}\text { Lactobacillus acidophilus } \\
\text { LA-5, Lacticaseibacillus } \\
\text { casei } 01 \text { and Bifidobacterium } \\
\text { animalis subsp. lactis Bb-12 }\end{array}$ & Viability (TO and PI) & $\begin{array}{l}\text { Ohmic heating treated samples } \\
\text { were centrifuged }(3500 \times g \times \\
\left.3 \text { min, } 4{ }^{\circ} \mathrm{C}\right) \text {, washed and } \\
\text { resuspended in PBS } \\
\text { Incubation }(10 \text { min, TO; } 5 \text { min; PI) } \\
\text { FCM, SEM, plate counts, Gram } \\
\text { staining, catalase test }\end{array}$ & [54] \\
\hline $\begin{array}{l}\text { PEF treatment } \\
\text { Model solution for liquid } \\
\text { foods }\end{array}$ & $\begin{array}{l}\text { Model solution containing } \\
\text { E. coli ATCC } 9637\end{array}$ & Viability (SG1PI) & $\begin{array}{c}\text { PEF treated E. coli suspension } \\
\left(\sim 10^{5} \text { cells } / \mathrm{mL}\right) \text { was immediately } \\
\text { stored on ice until staining } \\
\text { Incubation ( } 13 \text { min, SG1PI) } \\
\text { FCM and plate counts }\end{array}$ & [62] \\
\hline $\begin{array}{c}\text { Microbial food } \\
\text { safety-Contamination } \\
\text { monitoring of stainless } \\
\text { steel surfaces }\end{array}$ & $\begin{array}{l}\text { Sampling location: } \\
\text { Stainless steel conveyor } \\
\text { belts after cleaning } \\
\text { procedures } \\
\text { Reference strains: } \\
\text { E. coli ATCC } 10536 \\
\text { Sarcina lutea } \\
\text { Bacillus subtilis ATCC } 6633 \\
\text { S. aureus ATCC } 33592\end{array}$ & $\begin{array}{l}\text { Cellular redox potential and } \\
\text { cell sorting for the } \\
\text { identification and } \\
\text { discrimination between active } \\
\text { and non-active } \\
\text { sub-populations (BacLightTM } \\
\text { RedoxSensor }{ }^{\mathrm{TM}} \text { Green Vitality } \\
\text { Kit, including FITC-A and } \\
\text { PE-Texas Red-A) } \\
\text { Viability (fluorescein } \\
\text { isothiocyanate (FITC) and PI) }\end{array}$ & $\begin{array}{l}\text { Swabs of } 100 \mathrm{~cm}^{2} \text { stainless steel } \\
\text { areas within a fruit and vegetable } \\
\text { processing company were taken } \\
\text { and immediately placed in } 2 \mathrm{~mL} \\
1 \% \text { PBS solution } \\
\text { In situ analysis } \\
\text { Incubation (n.a. }{ }^{1} \text { ) } \\
\text { FCM, cell sorting, and CFU } \\
\text { enumeration }\end{array}$ & [3] \\
\hline
\end{tabular}

\footnotetext{
${ }^{1}$ n.a., no information was provided in the publication; ${ }^{2}$ EDTA, ethylenediaminetetraacetic acid; FCM, flow cytometry; PEF, pulsed electric
} fields; TCC, total cell count.

\subsection{Water and Bioaerosol FCM Applications}

This section focuses on the characterization of drinking water quality and wastewater purification [74] and bioaerosol detection [49,75-82]. Although FCM has been widely used for the microbial analysis of aquatic milieus (Table 2), it is less frequently used for the quantitative detection of bioaerosols (Table 3) [80,83].

Table 2. State-of-the-art FCM applications for water monitoring.

\begin{tabular}{|c|c|c|c|c|}
\hline $\begin{array}{c}\text { Research Area/Analyzed } \\
\text { Matrix }\end{array}$ & $\begin{array}{l}\text { Model Microorganism/ } \\
\text { Sample Type/ } \\
\text { Sample Location }\end{array}$ & $\begin{array}{l}\text { Detection Target, } \\
\text { Fluorochrome(s), and Gating }\end{array}$ & $\begin{array}{l}\text { Sample Preparation and } \\
\text { Observation Methods }\end{array}$ & References \\
\hline $\begin{array}{c}\text { Microbial particle } \\
\text { transition from } \\
\text { environmental to water } \\
\text { samples }\end{array}$ & $\begin{array}{c}\text { E. coli (three } \\
\text { environmental strains; one } \\
\text { modified pathogenic } \\
\text { strain) }\end{array}$ & $\begin{array}{c}\text { Viability (SYTO 11) and } \\
\text { propidium iodide (PI) and } \\
\text { VBNC state } \\
\text { Cell distinction is mainly } \\
\text { based on SSC scattering, as } \\
\text { unattached E. coli cells show } \\
\text { low SSC and attached cells } \\
\text { indicate high SSC }\end{array}$ & $\begin{array}{c}\text { E. coli strain, clay, PBS, and } \\
\text { fluorochromes were suspended at } \\
\text { defined volumes } \\
\text { Total assay time }(\sim 1 \mathrm{~h}) \\
\text { FCM vs. settling method }\end{array}$ & [84] \\
\hline Aquatic milieu/water & $\begin{array}{c}\text { Legionella pneumophila and } \\
\text { E. coli }\end{array}$ & $\begin{array}{c}\text { LIVE/DEAD }^{\circledR} \text { BacLight }^{\mathrm{TM}} \\
\text { Bacterial Viability Kit (SYTO } 9 \\
\text { and PI) }\end{array}$ & $\begin{array}{c}\text { Cells were harvested at an } \\
\text { exponential growth phase and } \\
\text { heat-treated according to the } \\
\text { experimental plan prior to FCM } \\
\text { analysis } \\
\text { Incubation (15 min, Syto 9, } 25 \mathrm{~min} \text {, } \\
\text { Syto } 9 \text { and PI) } \\
\text { FCM vs. propidium monoazide } \\
\text { quantitative PCR }\end{array}$ & [83] \\
\hline Drinking water & $\begin{array}{l}\text { Bacterial cells within the } \\
\text { native drinking water }\end{array}$ & $\begin{array}{c}\text { TCC and permeabilized } \\
\text { membranes (SYBR }{ }^{\circledR} \text { Green I } \\
\text { (SG1) and PI) } \\
\text { Gating to distinguish between } \\
\text { high- and } \\
\text { low-nucleic-acid-content } \\
\text { bacteria }\end{array}$ & $\begin{array}{l}\text { Collected at a drinking water tap } \\
\text { of a distribution system } \\
\text { Samples were buffered with } \\
10 \text { mM borate }(\mathrm{pH} 8.0) \\
\text { Incubation }(14-18 \mathrm{~min}) \\
\text { FCM }\end{array}$ & [82] \\
\hline
\end{tabular}


Table 2. Cont.

\begin{tabular}{|c|c|c|c|c|}
\hline $\begin{array}{c}\text { Research Area/Analyzed } \\
\text { Matrix }\end{array}$ & $\begin{array}{l}\text { Model Microorganism/ } \\
\text { Sample Type/ } \\
\text { Sample Location }\end{array}$ & $\begin{array}{l}\text { Detection Target, } \\
\text { Fluorochrome(s), and Gating }\end{array}$ & $\begin{array}{l}\text { Sample Preparation and } \\
\text { Observation Methods }\end{array}$ & References \\
\hline Drinking water & Drinking water samples & $\begin{array}{l}\text { TCC (SG1) and distinction } \\
\text { between high and low nucleic } \\
\text { content } \\
\text { Fixed gating between green } \\
\text { and red fluorescence was used, } \\
\text { whereas for low and high } \\
\text { nucleic acid content gates were } \\
\text { set on the green fluorescent } \\
\text { spectra }\end{array}$ & $\begin{array}{c}\text { n.a. }{ }^{1} \\
\text { Total assay time }(<15 \mathrm{~min}), \\
\text { incubation }(10 \mathrm{~min}) \\
\text { FCM }\end{array}$ & [81] \\
\hline Drinking water & $\begin{array}{l}\text { Groundwater site in } \\
\text { Switzerland (further used } \\
\text { for drinking water) }\end{array}$ & $\begin{array}{c}\text { TCC (SG1) } \\
\text { Gating to distinguish between } \\
\text { high- and } \\
\text { low-nucleic-acid-content } \\
\text { bacteria }\end{array}$ & $\begin{array}{l}\text { Sampling was conducted every } \\
15 \text { min during } 14 \text { days } \\
\text { Incubation (10 min) } \\
\text { Online FCM with automated } \\
\text { staining module }\end{array}$ & [75] \\
\hline Drinking water & $\begin{array}{l}\text { Samples from drinking } \\
\text { water treatment plant }\end{array}$ & $\begin{array}{c}\text { TCC (SG1) } \\
\text { Gating to distinguish between } \\
\text { high- and } \\
\text { low-nucleic-acid-content } \\
\text { bacteria }\end{array}$ & $\begin{array}{l}\text { Sampling every } 10 \text { min for } 10 \text { days } \\
\text { Total assay time }(10-30 \mathrm{~min}) \\
\text { incubation }(10 \mathrm{~min}) \\
\text { FCM and heterotrophic plate count }\end{array}$ & [78] \\
\hline Drinking water & $\begin{array}{c}\text { Sampling location: } \\
\text { incoming and existing } \\
\text { water streams of water } \\
\text { towers }\end{array}$ & $\begin{array}{l}\text { TCC (SG1) } \\
\text { Bray-Curtis dissimilarity }{ }^{2} \text { to } \\
\text { assess dissimilarities between } \\
\text { microbial communities }\end{array}$ & $\begin{array}{c}\text { Automated online sampling every } \\
40 \text { min from all streams } \\
\text { Real-time monitoring, incubation } \\
(20 \mathrm{~min}) \\
\text { Online FCM }\end{array}$ & [49] \\
\hline $\begin{array}{l}\text { Drinking water } \\
\text { Disinfection }\end{array}$ & $\begin{array}{l}\text { Fungal spore suspensions } \\
\text { (Asperigillus niger, } \\
\text { Trichoderma harzianum, and } \\
\text { Penicillium polonicum) }\end{array}$ & $\begin{array}{c}\text { Viability (SG1 and PI) } \\
\text { Esterase activity (cFDA) } \\
\text { Measurement of ROS levels } \\
\text { (dihydroethidium, DHE) }\end{array}$ & $\begin{array}{l}\text { EDTA was added to the spore } \\
\text { solution }\left(10^{5}-10^{6} \text { cells } / \mathrm{mL}\right) \\
\text { Incubation }(10 \mathrm{~min}, \mathrm{cFDA} ; 20 \mathrm{~min} \text {; } \\
\text { DHE; } 25 \mathrm{~min}, \mathrm{SG} 1 \mathrm{PI}) \\
\text { FCM and plate counts }\end{array}$ & [76] \\
\hline Wastewater monitoring & $\begin{array}{c}\text { Different wastewater } \\
\text { samples (bacteria and } \\
\text { viruses) }\end{array}$ & $\begin{array}{c}\text { Total bacterial count and } \\
\text { live/dead (SG1 + PI) } \\
\text { Total viral count (SG1 + EDTA) }\end{array}$ & $\begin{array}{l}\text { Samples were collected from a } \\
\text { wastewater treatment plant (in } \\
\text { northern China) } \\
\text { Total assay time ( } 45 \mathrm{~min}), \\
\text { Incubation (10 min, viruses; } \\
25 \text { min, bacteria) } \\
\text { FCM, ATP, and epifluorescence } \\
\text { microscopy }\end{array}$ & [85] \\
\hline
\end{tabular}

\footnotetext{
${ }^{1}$ n.a., no information was provided in the publication. ${ }^{2}$ The Bray-Curtis dissimilarity is derived from cytometric fingerprints. It quantifies the difference between two cytometric fingerprints. EDTA, ethylenediaminetetraacetic acid; FCM, flow cytometry; FISH, fluorescent in-situ hybridization; SSC, side scatter; TCC, total cell count; qPCR, quantitative PCR; VBNC, viable but nonculturable state.
}

Table 3. State-of-the-art FCM applications for bioaerosol detection.

\begin{tabular}{|c|c|c|c|c|}
\hline $\begin{array}{c}\text { Research Area/Analyzed } \\
\text { Matrix }\end{array}$ & $\begin{array}{c}\text { Model Microorganism/ } \\
\text { Sample Type/ } \\
\text { Sample Location }\end{array}$ & $\begin{array}{c}\text { Detection Target, } \\
\text { Fluorochrome(s), and Gating }\end{array}$ & $\begin{array}{l}\text { Sample Preparation and } \\
\text { Observation Methods }\end{array}$ & References \\
\hline $\begin{array}{l}\text { Bacterial quantification in } \\
\text { the air of an agricultural } \\
\text { environment (swine } \\
\text { confinement building) }\end{array}$ & E. coli & $\begin{array}{l}\text { A distinction of bacterial cells } \\
\text { from other debris }\left(4^{\prime}, 6-\right. \\
\text { diamidino-2-phenylindole } \\
\text { (DAPI) })\end{array}$ & $\begin{array}{c}\text { Aerosol collection with an all-glass } \\
\text { impinger- } 30 \text { and a May multistage } \\
\text { liquid impinge } \\
\text { Collection liquid (1\% peptone, } \\
\text { reverse-osmosis-purified } \mathrm{H}_{2} \mathrm{O} \\
\text { with } 0.01 \% \text { Tween } 80 \text { and } 0.005 \% \\
\text { Antifoam } \mathrm{A} \text { ) } \\
\text { Total sampling time: } 30 \mathrm{~min} \text {, flow } \\
\text { rate: } 12.5 \mathrm{~L} / \mathrm{min} \\
\text { Incubation (overnight) } \\
\text { FCM, fluorescence microscopy, } \\
\text { colony count and FISH }\end{array}$ & [80] \\
\hline
\end{tabular}


Table 3. Cont.

\begin{tabular}{|c|c|c|c|c|}
\hline $\begin{array}{c}\text { Research Area/Analyzed } \\
\text { Matrix }\end{array}$ & $\begin{array}{l}\text { Model Microorganism/ } \\
\text { Sample Type/ } \\
\text { Sample Location }\end{array}$ & $\begin{array}{l}\text { Detection Target, } \\
\text { Fluorochrome(s), and Gating }\end{array}$ & $\begin{array}{l}\text { Sample Preparation and } \\
\text { Observation Methods }\end{array}$ & References \\
\hline $\begin{array}{c}\text { Spore analysis and } \\
\text { differentiation to other } \\
\text { particles in air samples }\end{array}$ & $\begin{array}{l}\text { Phytophthora infestans } \\
\text { spores } \\
\text { Botrytis cinerea and } \\
\text { Alternaria alternata } \\
\text { (isolated from potato } \\
\text { tissues) }\end{array}$ & $\begin{array}{c}\text { Spore staining }\left[1,1^{\prime}, 3,3,3^{\prime}, 3^{\prime}-\right. \\
\text { hexamethylindodicarbo- } \\
\text { cyanine iodide }\left(\operatorname{DiIC}_{1}(5)\right), \\
\text { 3,3'-dipropylthiadicarbo- } \\
\text { cyanine iodide }\left(\mathrm{DiSC}_{3}(5)\right) \\
\text { TO-PRO-3 iodide, } \mathrm{SYTO} \text { dyes }^{\prime} \\
\text { (SYTO } 17,59,60,61,62,63 \text { and } \\
\text { 64), Nile Blue A, Calcocluor } \\
\text { white M2R] }\end{array}$ & $\begin{array}{l}\text { Suspensions were either filtered } \\
\text { through a single layer of muslin or } \\
\text { washed twice } \\
\text { Incubation (15 min in the dark) } \\
\text { FCM }\end{array}$ & [77] \\
\hline $\begin{array}{l}\text { Microbial contamination } \\
\text { in indoor air }\end{array}$ & Aspergillus versicolor & $\begin{array}{l}\text { FCM: Quantitative cell counts } \\
\text { and calibration (with gating of } \\
\text { FSC and SSC) } \\
\text { qPCR: SYBR }{ }^{\circledR} \text { Green } \\
\text { amplifications with Takara } \\
\text { master mix }\end{array}$ & $\begin{array}{c}\text { Bioaerosols were collected from } 38 \\
\text { mold-damaged homes with a } \\
\text { liquid cyclone air sampler } \\
\text { (Coriolis, Bertin Technologies) } \\
\text { FCM analysis time }(200 \mathrm{~s}), \\
\text { incubation (n.a. }{ }^{1} \text { ) } \\
\text { Real-time qPCR calibrated } \\
\text { with FCM }\end{array}$ & [86] \\
\hline
\end{tabular}

${ }^{1}$ n.a., no information was provided in the publication.

The determination of the total cell count (TCC) is probably the most straightforward FCM protocol available and requires only one nucleic acid binding stain. In 2012, TCC measurement via FCM was included in the guidelines for drinking water analysis in Switzerland [87]. The viability of live/dead analysis, with additional information on the intact cell count (ICC), can be supportive in analyzing the infectious risk, treatment efficiency, or inactivation process [88-90]. Here, the membrane integrity is targeted with a combination of cell-permeant and cell-impermeant nucleic acid stains. The most frequently used fluorochromes for this purpose are SYTO and SYBR stain families (cell-permeant dyes), i.e., SYBR ${ }^{\circledR}$ Green I (SG1) or SYTO $9^{\mathrm{TM}}$, together with propidium iodide (PI; cellimpermeant dye) [82,91]. Ma et al. [85] applied a rapid staining protocol with SG1-PI (green vs. red fluorescence) to quantify the TCC of bacteria and viruses, as well as the amount of live/dead bacterial cells during wastewater purification. An ultrasonication treatment was necessary to obtain free single cells for FCM analysis. With TCC measurement, even more complex datasets may be obtained, as fluorescence signals and scattered light create a so-called fingerprint of bacterial communities [92]. A study by Liang, Soupir, Rigby, Jarboe, and Zhang [84] distinguished environmental E. coli cells attached to clay or free from clay particles based on SSC gating.

Gating of SCC and green fluorescence allow the differentiation between bacteria with high and low nucleic acid contents [75,78,81,82]. Identifying and distinguishing between high- and low-nucleic-acid-content clusters can help to characterize water communities and are widely used for marine environments [81]. High-nucleic-acid-content cells were reported to be more sensitive and dynamic to changes, whereas low-nucleic-acid-content bacterial cells were associated with inactive or dead cells [82,93]. However, recent studies found out that bacteria containing low nucleic acid contents were metabolically active. A study by Prest et al. [81] linked drinking water contamination to increased high-nucleicacid-content cells. It demonstrated a correlation between a rise in TCC and that of high nucleic acid content concentrations. A recent study by Farhat et al. [78] suggested that highnucleic-acid-content bacteria showed increased sensitivity to chlorine dioxide, whereas low-nucleic-acid-content cells were more sensitive to ozone treatment. 
In addition to high and low nucleic acid content, cytometric fingerprints allow for more holistic data analysis. A study by Favere et al. [49] implemented the Bray-Curtis dissimilarity as an online tool to differentiate between microbial communities in drinking water. This parameter is an easy unequivocal tool and was first developed by Bray and Curtis [94]. Two fingerprints are compared in regard to their dissimilarity and valued between zero (identical samples) and one (entirely different samples) [95]. FCM fingerprinting enables rapid monitoring and a sensitive early warning of changes or contamination in aquatic milieus and provides real-time monitoring and detection within $10 \mathrm{~min}$ as a fully automated online tool $[49,75,92]$.

In contrast to water analysis, only a few publications have focused on the flow cytometrical detection of air-related microbes $[77,80,86]$. A study by Lange et al. [80] was the first to utilize FCM and FISH as a quantification and identification method for airborne microorganisms from agricultural surroundings and showed similar results to those obtained using fluorescence microscopy. For air sampling, an all-glass impinger-30 and a May multistage liquid impinger were used, comprising a collection liquid containing a surfactant (Tween 80) and an antifoaming agent (Antifoam A). Day et al. [77] differentiated air-borne Phytophtora infestans spores to pollen and other fungal spores by applying FSC, SSC, autofluorescent measurements, and the use of multiple gatings. Their study also demonstrated a more effective differentiation with the Calcofluor white M2R dye, which was characterized as non-toxic and showed a brighter fluorescence compared to other stains. One recent study coupled FCM and qPCR to quantify Aspergillus versicolor within indoor air [86]. A liquid cyclone air sampler was used for air sampling, and the particles were collected in sterile water. FCM was then used to rapidly count and calibrate A. versicolor particle concentrations before quantification with $\mathrm{qPCR}$.

\section{Specific State-of-the-Art Flow-FISH Methods and Applications for Monitoring and Detection}

\subsection{Principle of FISH}

DeLong, Wickham, and Pace [96] were the first to describe FISH for microorganisms. The method based on the use of fluorescently-labeled oligonucleotide probes that target a specific region of rRNA (16S/23S in Bacteria/Archaea or 18S/28S in Eukarya) enables the specific identification of microorganisms from the domain to the subspecies level [96-99]. It is now a well-established technique [100]. In addition to oligonucleotide probes, fluorescently labeled antibodies can also be used for the identification of microbial cells, but the low cost of oligonucleotide probes and the availability of a large number of rRNA sequences, as well as the associated possibility of the in silico design of oligonucleotide probes, have led to the preferred use of oligonucleotide probes [101].

In contrast to culture-dependent methods, microorganisms that are difficult to cultivate can be identified. FISH visualizes whole cells, and since abundant structures in living cells are targeted, it is possible to distinguish between viable and dead cells, which is the main advantage over other molecular techniques such as PCR-based methods [1,98]. Additionally, the direct observation of cells within their native environment is possible [102,103]. Flow-FISH, a combination of FISH and flow cytometry, was described in the early 1990s by R.I. Amann et al. [104]. The advantage of Flow-FISH is that the method enables the rapid analysis of larger sample volumes, while being more convenient since manual counting is omitted [105].

In general, FISH consists of four preparation steps: (i) fixation and permeabilization, (ii) probe hybridization with the target sequence, (iii) washing of excess and unbound probes, and (iv) observation of cells with epifluorescence microscopic techniques, scanning microscopy, or flow cytometry (Flow-FISH) [98,100,106]. Sampling, pre-preparation, and hybridization steps, compared to a typical FCM protocol for quantitative analysis, are illustrated in Figure 2. The fixation and permeabilization procedure of samples has several purposes. Cells have to be fixed to stabilize cell morphology and so that they can withstand further processing, and microbial contamination and decomposition are prevented [97]. Furthermore, fixation protects the RNA molecules from degradation, and permeabilization 
enables the fluorescent probes to penetrate into the cells [107]. Commonly used fixation and permeabilization agents are (para)formaldehyde and ethanol [98], whereas 3\%-4\% (para)formaldehyde has been shown to be sufficient for Gram-negative bacteria, and for Gram-positive bacteria 50\% ethanol, a mixture of ethanol and formalin (9:1), or heat treatment is suggested [107]. However, no standard fixation and permeabilization protocols are available since the cell wall composition of microorganisms differs, and modifications such as the addition of enzymes to digest peptidoglycan layers or proteinaceous cell walls, the addition of solvents to remove wax, or the addition of detergents are reported [101]. Following the fixation and permeabilization, oligonucleotide probes specifically bind to their target sequence in the hybridization step. Briefly, temperatures between $37^{\circ} \mathrm{C}$ and $50^{\circ} \mathrm{C}$ for $30 \mathrm{~min}$ to several hours in a dark, humid chamber are the conditions for hybridization [108]. Very stringent requirements for hybridization must be observed to ensure the specific binding of oligonucleotide probes to the target sequence. Additionally, the time and temperature needed for hybridization and the concentration of salts and denaturants have to be optimized for each application [98]. However, during the optimization of hybridization and washing conditions, it has to be considered that nonspecific hybridization at low temperatures and the loss of hybridized probes at high temperatures has to be avoided. The temperature affects the conformation of the targeted DNA or rRNA and, in addition to that, the accessibility of the target site to the probes. Moreover, the dissociation of the probe is affected by the temperature. Thus, the melting point of the probes, as well as the accessibility of the target site, determines the optimal hybridization and washing temperatures [108]. Formamide is commonly used in the hybridization buffer since it decreases the melting temperature by weakening the hydrogen bonds; thus, high stringency is achieved at lower hybridization temperatures [107]. Before the observation of the hybridized cells, a washing step is necessary to remove unbound and excessive probes to minimize false-positive detection [98]. Optionally, anti-fading agents are used to prevent the fluorescence from bleaching [107].

In general, DNA and RNA probes with a length of 15 to 30 nucleotides are used for FISH analyses with 16S rRNA as the predominant target sequence, but $23 \mathrm{~S}$ rRNA is gaining more importance in research since it might enable differentiation between closely related strains due to the longer length of the probes. Fluorescent dyes used for FISH are typically fluorescein, tetramethylrhodamine, Texas red, and carbocyanine dyes such as Cy3 and Cy5 [1,100]. Alexa Fluor dyes and quantum dots (nanosized crystal particles) are among the new generation of fluorophores [109]. The probes can be labeled with fluorophores in different ways (Figure 2). Labeling the $5^{\prime}$-end with one or more dye molecules is achieved chemically during synthesis through an amino linker. Terminal transferases are used to enzymatically attach fluorescently-labeled nucleotides to the $3^{\prime}$-end of the probes. Labeling of both the $5^{\prime}$-end and $3^{\prime}$-end lead to an increase in the fluorescent signal. This direct labeling of oligonucleotide probes is the most commonly used technique since it is the easiest, fastest, and cheapest method [107]. Indirect labeling in terms of enzymatic signal amplification was developed to increase the sensitivity of FISH. Thereby, the oligonucleotide probes were labeled with horseradish peroxidase and fluoresceintyramide as the substrate, leading to a 10-20-fold higher fluorescence signal due to signal amplification [110]. 


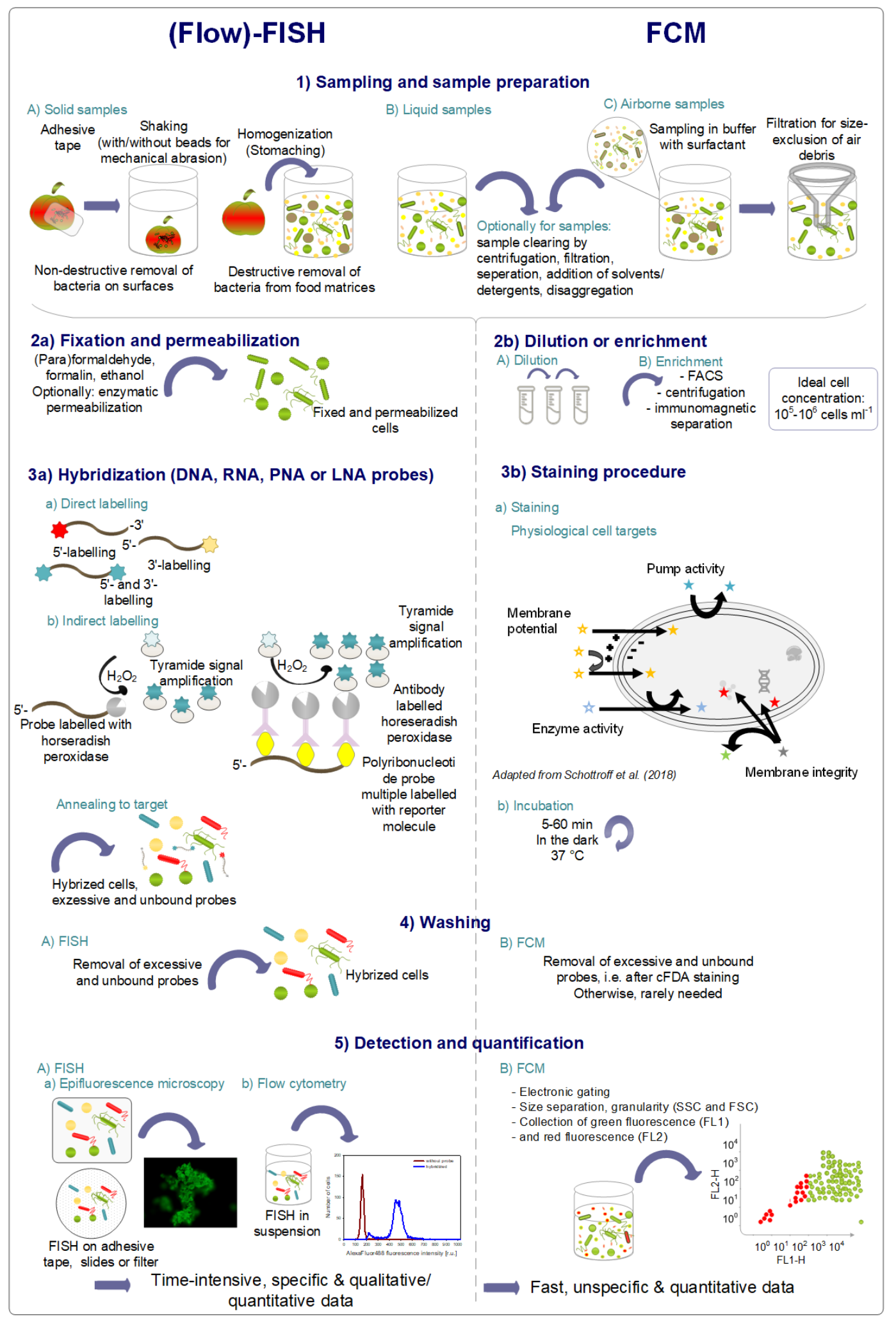

Figure 2. Standard sample preparation protocols and detection mechanisms of specific flow fluorescence in situ hybridization (FISH) and non-specific flow cytometry (FCM). LNA, locked nucleic acids; PNA, peptide nucleic acids.

Another approach to increase the sensitivity of FISH analyses was the use of polyribonucleotide probes labeled with several dye molecules or the use of polyribonucleotide probes labeled with the reporter molecule digoxygenin combined with the tyramide signal amplification method [111,112]. Alternatives to oligonucleotide probes are so-called 
DNA mimics such as peptide nucleic acids (PNA) and locked nucleic acids (LNA) [109]. PNA is a synthesized DNA, having a comparatively high affinity to nucleic acids because the sugar-phosphate backbone (negative charge) is replaced with a pseudo-peptide [19]. Due to this non-charged polyamide backbone, PNA molecules are less susceptible to salt concentrations and repulsive forces, and therefore higher thermal stability between PNA and target is achieved. Other advantages of PNA are its ability to hybridize with nucleic acids at low salt concentrations and high temperatures, the stability of the molecule during storage, and its enhanced diffusion into the cells due to its nonpolar characterization with the ability to penetrate even into biofilm structures [1]. LNA is an RNA analogue in which the ribose ring between the $2^{\prime}$ oxygen and the $4^{\prime}$ carbon is locked by a methylene bond. This increases the local organization of the phosphate backbone and reduces the conformational flexibility of the ribose. The basic advantage of LNA is the possibility to speed up the hybridization process due to the possibility of increasing the melting temperature [19].

\subsection{Flow-FISH in Food Microbiology}

Flow-FISH in food microbiology is used to detect microorganisms in food products or for biofilm studies on abiotic surfaces, e.g., food contact surfaces. For food products, the range of food products examined is wide, from vegetables, meat, fish products, and dairy products to vinegar, wine, beer, and water. An overview is listed in Table 4.

Table 4. FISH applications for microorganism detection in food matrices and abiotic surfaces.

\begin{tabular}{|c|c|c|c|c|}
\hline Sample & Target Microorganisms & $\begin{array}{c}\text { Target Probe }\left(5^{\prime}-3^{\prime} \text { Sequence }\right) \text { and } \\
\text { Fluorophore }\end{array}$ & $\begin{array}{c}\text { Sample Prepara- } \\
\text { tion/Fixation/Observation } \\
\text { Method }\end{array}$ & References \\
\hline $\begin{array}{l}\text { Tomato; Jalapeno; } \\
\text { Cilantro; Spinach }\end{array}$ & $\begin{array}{l}\text { Salmonella spp. } \\
\quad \text { (spiked) }\end{array}$ & $\begin{array}{c}\text { 23S: Sal3/Salm-63 cocktail } \\
\text { Fluorophore: fluorescein; TexasRed, } \\
\text { Cy5 }\end{array}$ & $\begin{array}{l}\text { Bacterial removal: adhesive tapes } \\
\text { Liquid phase enrichment: } \\
\text { tape + TSB or BPW }\left(5 \mathrm{~h}, 37^{\circ} \mathrm{C}\right) \\
\text { Fixation: pelleted }(5 \mathrm{~min}, 2000 \times \mathrm{g}) \\
10 \% \text { formalin }\left(30 \mathrm{~min}, 25^{\circ} \mathrm{C}\right) \\
\text { Fluorescence microscopy; flow } \\
\text { cytometry }\end{array}$ & [113] \\
\hline Olive & $\begin{array}{l}\text { L. plantarum } \\
\text { (spiked/natural) }\end{array}$ & $\begin{array}{c}\text { 16S: LbpV3 } \\
\text { (CCGTCAATACCTGAACAG) } \\
\text { Fluorophore: fluorescein }\end{array}$ & $\begin{array}{l}\text { Bacterial removal: olives in } \\
\text { Ringer's solution (overnight, RT, } \\
\text { shaking); pelleted ( } 8000 \mathrm{rpm}, \\
5 \text { min, RT); Ringer's solution; } \\
\text { Fixation: } 4 \% \text { paraformaldehyde } \\
\text { Fluorescence microscopy }\end{array}$ & [114] \\
\hline Sprouts & $\begin{array}{l}\text { S. Typhimurium } \\
\text { (spiked) }\end{array}$ & $\begin{array}{c}\text { 23S: Sal-3 } \\
\text { (AATCACTTCACCTACGTG) } \\
\text { 23S: Salm-63 } \\
\text { (GCTGCCTCCCGTAGGAGT) } \\
\text { Fluorophore: Cy5; 6-FAM }\end{array}$ & $\begin{array}{c}\text { Bacterial removal: sprouts }+0.1 \% \\
\text { PW homogenized (1 min, } \\
230 \mathrm{rpm}) \text {; vacuum filtered (4 layers } \\
\text { of sterile cheesecloth; centrifuged } \\
(300 \times g, 30 \mathrm{~s}) ; \\
\text { Fixation: supernatant } 10 \% \\
\text { formalin }(1: 2) 30 \mathrm{~min} \\
\text { Fluorescence microscopy; Flow } \\
\text { cytometry }\end{array}$ & [115] \\
\hline Swine carcasses & $\begin{array}{l}\text { Salmonella spp. } \\
\quad \text { (natural) }\end{array}$ & $\begin{array}{c}\text { 23S: Sal3 } \\
\text { (AATCACTTCACCTACGTG) } \\
\text { Fluorophore: fluorescein }\end{array}$ & $\begin{array}{c}\text { Bacterial removal: swab + BPW } \\
\text { w }+0.1 \% \text { Tween } 80 ; \text { homogenized } \\
\text { (90 s) } \\
\text { Pre-enrichment: } 37^{\circ} \mathrm{C}, 18 \mathrm{~h} \\
\text { Fixation: centrifugation } \\
(14,000 \mathrm{rpm}, 10 \text { min), washed twice } \\
\text { (PBS); } 4 \% \text { paraformaldehyde }(2 \mathrm{~h}) \\
\text { Fluorescence microscopy }\end{array}$ & [116] \\
\hline
\end{tabular}


Table 4. Cont.

\begin{tabular}{|c|c|c|c|c|}
\hline Sample & Target Microorganisms & $\begin{array}{c}\text { Target Probe }\left(5^{\prime}-3^{\prime} \text { Sequence }\right) \text { and } \\
\text { Fluorophore }\end{array}$ & $\begin{array}{c}\text { Sample Prepara- } \\
\text { tion/Fixation/Observation } \\
\text { Method }\end{array}$ & References \\
\hline Swine carcasses & $\begin{array}{l}\text { Salmonella spp. } \\
\quad \text { (natural) }\end{array}$ & $\begin{array}{c}\text { 23S: Sal3 } \\
\text { (AATCACTTCACCTACGTG) } \\
\text { Fluorophore: fluorescein }\end{array}$ & $\begin{array}{c}\text { Bacterial removal: swab + BPW } \\
\text { w + 0.1\% Tween } 80 \text {; homogenized } \\
(90 \mathrm{~s}) \\
\text { Pre-enrichment: } 37^{\circ} \mathrm{C}, 18 \mathrm{~h} \\
\text { Fixation: centrifugation } \\
(19,500 \mathrm{rpm}, 10 \text { min), washed twice } \\
\text { (PBS); } 4 \% \text { paraformaldehyde }(4 \mathrm{~h}) \\
\text { Fluorescence microscopy }\end{array}$ & [117] \\
\hline Minced pork meat & $\begin{array}{l}\text { Yersinia spp. } \\
\text { (spiked) }\end{array}$ & $\begin{array}{c}\text { 16S: YersEcoI16 (TATTAAGT- } \\
\text { TATTGGCCTTCCTCCT) } \\
\text { 16S: YersEcoII16 (TTAACCTTTAT- } \\
\text { GCCTTCCTCCTC) } \\
\text { 23S: YersEco23 (CAAGTCCCTT- } \\
\text { TACCTAATGCCAGC) } \\
\text { 23S: YersPseu23 (ATCACGC- } \\
\text { CTCAGGGTTGATAAG) } \\
\text { 16S: YersPseu16 (GCGTAT- } \\
\text { TAAACTCAACCCCTTCC) } \\
\text { 23S, LNA: YersPest1523-TexasRed } \\
\text { (CTGCACCGTGGTGCATCGTC) } \\
\text { 23S, LNA: YersPseu1523-Alexa488 } \\
\text { (CTGCACCGTAGTGCATCGTC) } \\
\text { 16S: Yersall-Demaneche } \\
\text { (GTTCGCTTCACTTTGTATCT) } \\
\text { 16S: EUB-338 } \\
\text { (GCTGCCTCCCGTAGGAGT) } \\
\text { Fluorophore: Alexa488, TexasRed }\end{array}$ & $\begin{array}{c}\text { Selective enrichment: PSB and ITC } \\
\text { broth }(48 \mathrm{~h}) \\
\text { Fixation: pelleted }(14,000 \times g) ; 4 \% \\
\text { PBS/formaldehyde }\left(2 \mathrm{~h}, 4^{\circ} \mathrm{C}\right) \\
\text { Fluorescence microscopy }\end{array}$ & [118] \\
\hline Pork sausage & $\begin{array}{c}\text { S. enterica } \\
\text { (spiked/natural) }\end{array}$ & $\begin{array}{c}\text { 23S: Sal-3 } \\
\text { (AATCACTTCACCTACGTG) } \\
\text { Fluorophore: fluorescein } \\
\text { isothiocyanate (FITC) }\end{array}$ & $\begin{array}{l}\text { Pre-enrichment: nutrient broth } \\
\left(12 \mathrm{~h}, 37^{\circ} \mathrm{C}\right) \\
\text { Fixation: pelleted }(12,500 \mathrm{rpm}, \\
3 \mathrm{~min}) ; 4 \% \text { paraformaldehyde }(1 \mathrm{~h}, \\
\left.4{ }^{\circ} \mathrm{C}\right) \\
\text { Fluorescence microscopy }\end{array}$ & [119] \\
\hline $\begin{array}{l}\text { Ground beef; Ground } \\
\text { pork; Milk; Lettuce; } \\
\text { Cooked shrimp }\end{array}$ & L. monocytogenes (spiked) & $\begin{array}{c}\text { PNA: LmPNA1253 } \\
\text { (GACCCTTTGTACTAT) } \\
\text { Fluorophore: Alexa Fluor } 568\end{array}$ & $\begin{array}{l}\text { Pre pre-enrichment: One Broth } \\
\text { Listeria }(24 \mathrm{~h}) ; 1: 10 \text { dilution in One } \\
\text { Broth Listeria (18 h) } \\
\text { Fixation: Smears on slides; } 4 \% \\
\text { paraformaldehyde (10 min); } 50 \% \\
\text { ethanol (10 min); air dry } \\
\text { Fluorescence microscopy }\end{array}$ & [120] \\
\hline Ground beef & $\begin{array}{l}\text { Clostridium perfringens } \\
\quad \text { (spiked) }\end{array}$ & $\begin{array}{c}\text { 16S: CLP-180 (AATGATGATGC- } \\
\text { CATCTTTCAACA) } \\
\text { Fluorophore: } \\
\text { carboxytetramethylrhodamine } \\
\text { (TAMRA) }\end{array}$ & $\begin{array}{c}\text { Bacterial removal: sample }+0.1 \% \\
\text { peptone water ( } 30 \mathrm{~s} \text { homogenized) } \\
\text { FISH in combination with filter } \\
\text { cultivation: } 0.1 \mathrm{~mL} \text { food } \\
\text { homogenate }+4 \mathrm{~mL} \text { TSC-broth; } \\
\text { filtered (hydrophilic } \\
\text { polypropylene membrane filters); } \\
\text { incubation }\left(37^{\circ} \mathrm{C}, 6 \mathrm{~h}\right) \\
\text { Fixation: } 2 \mathrm{~mL} \text { of ethanol }(99.5 \%) \\
\text { (RT, } 15 \mathrm{~min}) \\
\text { Fluorescence microscopy }\end{array}$ & [121] \\
\hline Chicken & C. jejuni (spiked/natural) & $\begin{array}{c}\text { 16S: CAM } 1 \text { probe } \\
\text { Fluorophore: } \\
\text { 5(6)-carboxyfluorescein-N- } \\
\text { hydroxysuccinimide ester } \\
\text { (FLUOS); tetramethylrhodamine-5- } \\
\text { isothyocyanate } \\
\text { (TRITC) }\end{array}$ & $\begin{array}{c}\text { Bacterial removal: irradiated } \\
\text { product + nutrient broth }(2 \mathrm{~min} \\
\text { homogenized); incubation }(1 \mathrm{~h} \text { at } \\
\left.37^{\circ} \mathrm{C}\right) \\
\text { Pre-enrichment: pre-enrichment } \\
\text { broth + Preston selective broth } \\
\text { (microaerophilic, } 37^{\circ} \mathrm{C}, 22 \mathrm{~h} \\
\text { Fixation: pelleted; } 4^{\circ} \% \\
\text { paraformaldehyde }\left(2 \mathrm{~h}, 4^{\circ} \mathrm{C}\right) \\
\text { Fluorescence microscopy }\end{array}$ & [122] \\
\hline
\end{tabular}


Table 4. Cont.

\begin{tabular}{|c|c|c|c|c|}
\hline Sample & Target Microorganisms & $\begin{array}{c}\text { Target Probe }\left(5^{\prime}-3^{\prime} \text { Sequence }\right) \text { and } \\
\text { Fluorophore }\end{array}$ & $\begin{array}{c}\text { Sample Prepara- } \\
\text { tion/Fixation/Observation } \\
\text { Method }\end{array}$ & References \\
\hline Chicken breast & $\begin{array}{l}\text { C. jejuni } \\
\text { (spiked) }\end{array}$ & $\begin{array}{c}\text { 23S: Campy268 } \\
\text { (AACCCCAGTGCAAG- } \\
\text { CACTGGGTTT)23S, LNA: } \\
\text { CampyLNA268 } \\
\text { (CCCCCAGTGCAAGCACTGGGTTT) } \\
\text { 23S: Campy696 } \\
\text { (CACTAGTTCTTACAC- } \\
\text { TAGCTTCAACTTGC) } \\
\text { 23S: Campy835 } \\
\text { (CTACCCCCTATATTACGACA- } \\
\text { CAACGC) } \\
\text { 23S: Campy1508 } \\
\text { (AGCCTTTCAGTTCTCGGAGT) } \\
\text { 23S: Campy2124 } \\
\text { (CTGGCGTCATATACTCAAAGC- } \\
\text { CTC) } \\
\text { 23S: Campytherm } \\
\text { (CTTAGCCCTAAGCGTCCTT) } \\
\text { Fluorophore: Alexa488, Texas Red, } \\
\text { AMCA }\end{array}$ & $\begin{array}{l}\text { Pre-enrichment: } 1: 10 \text { in Bolton } \\
\text { broth, }(1 \mathrm{~min} \text { homogenized); } \\
\text { incubation (microaerophilic } 4 \mathrm{~h} \text {; } \\
\left.37^{\circ} \mathrm{C}+44 \mathrm{~h}, 42^{\circ} \mathrm{C}\right) \\
\text { Fixation: } 4 \% \text { formaldehyde } \\
\text { (15 min); washed two times in } \\
\text { water and end-fixed in } 95 \% \\
\text { ethanol ( } 5 \text { min) } \\
\text { Fluorescence microscopy }\end{array}$ & [10] \\
\hline Minced lamb meat & $\begin{array}{l}\text { Salmonella Enteritidis } \\
\quad \text { (spiked) }\end{array}$ & $\begin{array}{c}\text { 23S: Salm63 } \\
\text { (TCGACTGACTTCAGCTCC) } \\
\text { Fluorophore: Сy3 }\end{array}$ & $\begin{array}{c}\text { Pre-enrichment: } \mathrm{BPW}\left(37^{\circ} \mathrm{C}, 18 \mathrm{~h}\right) \\
\text { Fixation: } 4 \% \text { paraformaldehyde } \\
(30 \mathrm{~min} \text {, refrigerated }) \\
\text { Fluorescence microscopy }\end{array}$ & [123] \\
\hline $\begin{array}{l}\text { Chicken scraps and } \\
\text { gizzards; Beef; Pork; } \\
\text { Bacon; Salami; Sausage; } \\
\text { Fish; Egg; Milk; Milk } \\
\text { powder; Cheese; Butter; } \\
\text { Ice cream; Pudding; Bell } \\
\text { pepper; Lettuce; Bean } \\
\text { sprouts }\end{array}$ & $\begin{array}{l}\text { Salmonella Panama } \\
\text { (spiked); } \\
\text { Salmonella spp. } \\
\text { (natural) }\end{array}$ & $\begin{array}{c}\text { 23S: Sal-1 } \\
\text { (ACAGCACATGCGCTTTTGTG) } \\
\text { 23S: Sal-3 } \\
\text { (AATCACTTCACCTACGTG) } \\
\text { 23S: Sal-544 } \\
\text { (GCAGTCACACAGGTAAAC) } \\
\text { Fluorophore: Cy3 }\end{array}$ & $\begin{array}{l}\text { Pre-enrichment: BPW (up to } 24 \mathrm{~h} \text {, } \\
\left.37^{\circ} \mathrm{C}\right) \\
\text { Fixation: pelleted }(13,000 \mathrm{rpm}, \\
2 \text { min); } 3.7 \% \text { formaldehyde }\left(4{ }^{\circ} \mathrm{C} \text {, }\right. \\
1 \mathrm{~h}) \\
\text { Fluorescence microscopy }\end{array}$ & [124] \\
\hline $\begin{array}{l}\text { Fermented sausages; } \\
\text { Cured ham; Turkey } \\
\text { meat; Lamb meat; } \\
\text { Chicken meat; Minced } \\
\text { meat (pork and beef); } \\
\text { Beef meat; Cottage } \\
\text { cheese; Semi-hard } \\
\text { cheese; Fresh cheese }\end{array}$ & $\begin{array}{l}\text { Natural microbial } \\
\text { community }\end{array}$ & $\begin{array}{c}\text { 16S: EUB338 } \\
\text { (GCTGCCTCCCGTAGAGT) } \\
\text { 16S: ALF968 } \\
\text { (GGTAAGGTTCTGCGCGTT) } \\
\text { 23S: Bet42a } \\
\text { (GCCTTCCCACTTCGTTT) } \\
\text { 23S: Gam42a } \\
\text { (GCCTTCCCACATCGTTT) } \\
\text { 23S: HGC69a } \\
\text { (TATAGTTACCACCGCCGT) } \\
\text { 16S: LGC354ab } \\
\text { (YGGAAGATTCCCTACTGC) } \\
\text { 16S: Pae } \\
\text { (TCTGGAAAGTTCTCAGCA) } \\
\text { 16S: Sth } \\
\text { (CATGCCTTCGCTTACGCT) } \\
\text { 18S: EUK } \\
\text { (ACCAGACTTGCCCTCC) } \\
\text { Fluorophore:Cy3, } \\
\text { 6-carboxyfluorescein (6-FAM) }\end{array}$ & $\begin{array}{l}\text { Bacterial removal meat: PBS (1:4); } \\
\text { mixed (5 min); filtered; pelleted } \\
\text { (8000 rpm, } 10 \text { min) } \\
\text { Bacterial removal cheese: PBS (1:4); } \\
\text { mixed (5 min); two times } \\
\text { centrifugation (buffer (100 mM } \\
\mathrm{Na}_{2} \mathrm{HPO}_{4}, 150 \mathrm{mM} \mathrm{NaCl}, 10 \mathrm{mM} \\
\mathrm{EDTA}_{4} 40 \mathrm{mM} \text { NaOH); } 8000 \mathrm{rpm}, \\
2 \mathrm{~min}) \\
\text { Fixation: ethanol/PBS (1:1) } \\
\text { Fluorescence microscopy }\end{array}$ & [125] \\
\hline $\begin{array}{l}\text { Smoked salmon; } \\
\text { Camembert; Uncured } \\
\text { ham }\end{array}$ & Listeria spp. (spiked) & $\begin{array}{l}\text { 23S: Lis-1400 (CGCACATTTC- } \\
\text { CATTCGTGCGATTCC) } \\
\text { Fluorophore: TAMRA }\end{array}$ & $\begin{array}{l}\text { Bacterial removal: sample }+0.85 \% \\
\mathrm{NaCl}(30 \text { s homogenized) } \\
\text { FISH in combination with filter } \\
\text { cultivation: } 0.1 \mathrm{~mL} \text { food } \\
\text { homogenate }+4 \mathrm{~mL} \text { TSC-broth; } \\
\text { filtered (hydrophilic } \\
\text { polypropylene membrane filters); } \\
\text { incubation }\left(37^{\circ} \mathrm{C}, 12 \mathrm{~h}\right) \\
\text { Fixation: ethanol }(30 \mathrm{~min}) \\
\text { Fluorescence microscopy }\end{array}$ & [126] \\
\hline
\end{tabular}


Table 4. Cont.

\begin{tabular}{|c|c|c|c|c|}
\hline Sample & Target Microorganisms & $\begin{array}{c}\text { Target Probe }\left(5^{\prime}-3^{\prime} \text { Sequence) and }\right. \\
\text { Fluorophore }\end{array}$ & $\begin{array}{c}\text { Sample Prepara- } \\
\text { tion/Fixation/Observation } \\
\text { Method }\end{array}$ & References \\
\hline $\begin{array}{l}\text { Smoked salmon; } \\
\text { Mozzarella; Julienne } \\
\text { cabbage }\end{array}$ & L. monocytogenes (spiked) & $\begin{array}{l}\text { 16S: mRL-2 (AGAATAGTTT- } \\
\text { TATGGGATTAGCTCCACC) } \\
\text { Fluorophore: Alexa647 }\end{array}$ & $\begin{array}{l}\text { Bacterial removal: sample }+0.85 \% \\
\mathrm{NaCl}(30 \text { s homogenized) } \\
\text { FISH in combination with filter } \\
\text { cultivation: } 0.1 \mathrm{~mL} \text { food } \\
\text { homogenate }+4 \text { mL TSC-broth; } \\
\text { filtered (hydrophilic } \\
\text { polypropylene membrane filters); } \\
\text { incubation }\left(37^{\circ} \mathrm{C}, 12 \mathrm{~h}\right) \\
\text { Fixation: } 50 \% \text { ethanol }(1 \mathrm{~h}) \\
\text { Fluorescence microscopy }\end{array}$ & [127] \\
\hline $\begin{array}{l}\text { Ikura (traditional } \\
\text { Japanese seafood); } \\
\text { Minced chicken meat }\end{array}$ & $\begin{array}{l}\text { E. coli } \\
\text { (spiked) }\end{array}$ & $\begin{array}{l}\text { 16S: Enterobacteriaceae } \\
\text { (TGCTCTCGCGAG- } \\
\text { GTCGCTTCTCTT) } \\
\text { Fluorophore: TAMRA }\end{array}$ & $\begin{array}{l}\text { Bacterial removal: sample }+0.8 \% \\
\mathrm{NaCl}(2 \mathrm{~min} \text { homogenized) } \\
\text { FISH in combination with filter } \\
\text { cultivation: vacuum filtered } \\
\text { through Isopore membrane filter } \\
(0.4 \mu \mathrm{m} \text { pore size); filter incubation } \\
\left(6 \mathrm{~h} \text { at } 37^{\circ} \mathrm{C}, \mathrm{TSB}\right) \\
\text { Fixation: ethanol (RT) } \\
\text { Fluorescence microscopy }\end{array}$ & [128] \\
\hline Zebra mussels & $\begin{array}{l}\text { Cryptosporidium parvum, } \\
\text { Giardia lamblia, } \\
\text { Encephalitozoon intestinalis, } \\
\text { Encephalitozoon hellem, } \\
\text { Enterocytozoon bieneusi } \\
\text { (natural) }\end{array}$ & $\begin{array}{c}\text { Cry-1 } \\
\text { (CGGTTATCCATGTAAAAG) } \\
\text { Giar-4 } \\
\text { (CGGCGGGGGCCAATTAC) } \\
\text { Giar-6 } \\
\text { (CGGGGCTGCCGCGGCGCG) } \\
\text { HEL878F } \\
\text { (ACTCTCACACTAACTTCAG) } \\
\text { INT-1 } \\
\text { (GTTCTCCTGCCCGCTTCAG) } \\
\text { BIEN-1 } \\
\text { (AUCAACGAAUGACUUGA) } \\
\text { Fluorophore: HEX, 6-FAM, Tet }\end{array}$ & $\begin{array}{l}\text { Bacterial removal: mussel flesh } \\
\text { was homogenized with sterile PBS; } \\
\text { the homogenate was sieved, } \\
\text { sedimented, and purified over a } \\
\mathrm{CsCl}_{2} \text { gradient } \\
\text { Fluorescence microscopy }\end{array}$ & [129] \\
\hline Stilton cheese & $\begin{array}{l}\text { Bacteria } \\
\text { (natural) }\end{array}$ & $\begin{array}{l}\text { 16S: S-D-Bact-0338-a-A-18 } \\
\text { Fluorophore: fluorescein }\end{array}$ & $\begin{array}{c}\text { Fixation: cheese }(0.5 \times 0.3 \times \\
1 \mathrm{~cm})+3.7 \% \text { formaldehyde in PBS } \\
(3 \mathrm{~h}) ; \text { washed in } 6.8 \% \text { sucrose } \\
\text { solution in PBS (overnight), } \\
\text { dehydrated in acetone }(1 \mathrm{~h}), \\
\text { infiltrated with a plastic solution } \\
(8 \mathrm{~h}) \text {; mixed with hardener II } \\
(5 \mathrm{~min}), \text { covered with cover foil } \\
\left(4^{\circ} \mathrm{C}, 5 \mathrm{~h}\right) ; 5 \mu \mathrm{m} \text { sections were cut } \\
\left(\text { cryostat, } 4^{\circ} \mathrm{C}\right), \text { immediately } \\
\text { straightened in sterile water, } \\
\text { attached to lysine-coated slides, } \\
\text { air-dried } \\
\text { Fluorescence microscopy }\end{array}$ & [130] \\
\hline Livarot cheese & $\begin{array}{l}\text { Bacteria, Yeasts, Candida } \\
\text { catenulata, Candida } \\
\text { intermedia, Geotrichum } \\
\text { spp., Yarrowia lipolytica } \\
\text { (natural) }\end{array}$ & $\begin{array}{c}\text { 16S: EUB338 } \\
\text { (GCTGCCTCCCGTAGGAGT) } \\
\text { 23S: Gam42a } \\
\text { (GCCTTCCCACATCGTTT) } \\
\text { 23S: HGC69a } \\
\text { (TATAGTTACCACCGCCGT) } \\
\text { 18S: EUK516 } \\
\text { (ACCAGACTTGCCCTCC) } \\
\text { 26S: Ccat } \\
\text { (TTTATCTCCCGCGCCT) } \\
\text { 26S: Cint } \\
\text { (TTATCCACCCCTAGCA) } \\
\text { 26S: Geo } \\
\text { (TTACGGGGCTGTCACCCT) } \\
\text { 26S: Ylip (CACTCATTTCCTTCCC) } \\
\text { Fluorophore: FITC, Cy3, rhodamine }\end{array}$ & $\begin{array}{c}\text { Bacterial removal: cheese } \\
\text { rind }+10 \mathrm{~mL}(2 \%) \text { trisodiumcitrate } \\
\text { (homogenized: } 8000 \mathrm{rpm}, 1 \mathrm{~min}) \\
\text { pelleted and resuspended in } 1 \times \\
\text { PBS } \\
\text { Fixation: ice-cold } 4 \% \\
\text { paraformaldehyde }\left(4{ }^{\circ} \mathrm{C}, 4 \mathrm{~h}\right) \\
\text { Fluorescence microscopy }\end{array}$ & [131] \\
\hline
\end{tabular}


Table 4. Cont.

\begin{tabular}{|c|c|c|c|c|}
\hline Sample & Target Microorganisms & $\begin{array}{c}\text { Target Probe }\left(5^{\prime}-3^{\prime} \text { Sequence) and }\right. \\
\text { Fluorophore }\end{array}$ & $\begin{array}{c}\text { Sample Prepara- } \\
\text { tion/Fixation/Observation } \\
\text { Method } \\
\end{array}$ & References \\
\hline Gruyère cheese & $\begin{array}{l}\text { Bacteria; Actinobacteria, } \\
\text { Brevibacterium (natural } \\
\text { load) }\end{array}$ & $\begin{array}{c}\text { 16S: EUB338 (all bacteria) } \\
\text { 16S: HGC1901 (Actinobacteria) } \\
\text { 16S: BRE1239 (Brevibacteria) } \\
\text { Fluorophore: Cy3 }\end{array}$ & $\begin{array}{l}\text { Bacterial removal: } 10 \mathrm{~cm}^{2} \text { of the } \\
\text { surface }+0.8 \% \mathrm{NaCl} / 0.1 \% \text { peptone } \\
\text { solution (homogenized: } 2 \mathrm{~min}) \\
\text { Fixation: pelleted }(7000 \times g, 5 \mathrm{~min}) \text {; } \\
4 \% \text { paraformaldehyde } / \mathrm{PBS}\left(4^{\circ} \mathrm{C},\right. \\
12 \mathrm{~h}) \\
\text { Fluorescence microscopy }\end{array}$ & [132] \\
\hline Gruyère cheese & $\begin{array}{c}\text { Propionibacterium } \\
\text { freudenreichii (natural) }\end{array}$ & $\begin{array}{l}\text { 16S: Pfr435 (CTTGCGCTTCGT- } \\
\text { CATGGATGAAAG) } \\
\text { Fluorophore: 6-FAM }\end{array}$ & $\begin{array}{c}\text { Bacterial removal: } 10 \mathrm{~g} \\
\text { cheese }+2 \% \text { trisodium citrate } \\
\text { (homogenized: } 2 \text { min), repeatedly } \\
\text { filtered with sterile gauzes; cells } \\
\text { were washed four times with } \\
\text { sterile PBS and resuspended in } \\
1 / 10 \text { of the original volume; } \\
\text { Fixation: cold } 4 \% \\
\text { paraformaldehyde }\left(4{ }^{\circ} \mathrm{C}, 16 \mathrm{~h}\right) \\
\text { Fluorescence microscopy }\end{array}$ & [133] \\
\hline Italian cheese & $\begin{array}{l}\text { Enterococcus italicus } \\
\quad \text { (natural) }\end{array}$ & $\begin{array}{c}\text { 16S: ESA452 } \\
\text { (CATTCTCTTCTCATCCTT) } \\
\text { Fluorophore: Сy3 }\end{array}$ & $\begin{array}{c}\text { Bacterial removal: cheese }+ \text { sterile } \\
2 \% \text { sodium citrate solution } \\
(\text { homogenized); centrifuged } \\
\left(8000 \times g, 15 \mathrm{~min}, 4^{\circ} \mathrm{C}\right) \text { repeated } \\
\text { washings }(3-5 \text { times }) \text { with same } \\
\text { buffer, pellets were dissolved in } \\
\text { PBS } \\
\text { Fixation: freshly prepared cold } \\
\text { paraformaldehyde solution }(4 \% \text { in } \\
\text { PBS })\left(4^{\circ} \mathrm{C}, 16 \mathrm{~h}\right) \\
\text { Fluorescence microscopy }\end{array}$ & [134] \\
\hline Egg; Milk; Mayonnaise & $\begin{array}{l}\text { S. Enteritidis } \\
\text { (spiked) }\end{array}$ & $\begin{array}{l}\text { PNA (details not specified) } \\
\text { Fluorophore: AlexaFluor } 594\end{array}$ & $\begin{array}{c}\text { Pre-enrichment: } \\
\text { sample }+ \text { pre-warmed BPW } \\
\left(18-21 \mathrm{~h}, 37^{\circ} \mathrm{C}\right) \\
\text { Fixation: } 4 \% \text { paraformaldehyde } \\
\text { Fluorescence microscopy }\end{array}$ & [135] \\
\hline $\begin{array}{c}\text { Ground beef; } \\
\text { Unpasteurized milk }\end{array}$ & E. coli $\mathrm{O} 157$ (spiked) & $\begin{array}{l}\text { 23S, PNA: EcoPNA1169 } \\
\text { (CAACACACAGTGTC) } \\
\text { Fluorophore: AlexaFluor } 594\end{array}$ & $\begin{array}{c}\text { Pre-enrichment: } \\
\text { sample + pre-warmed BPW or } \\
\text { TSB+ novobiocin }\left(18-21 \mathrm{~h}, 37^{\circ} \mathrm{C} \text { or }\right. \\
\left.41^{\circ} \mathrm{C}\right) \\
\text { Fixation: } 4 \% \text { paraformaldehyde; } \\
\text { pretreatment with } 1 \% \text { Triton X-100 } \\
\text { to remove background } \\
\text { fluorescence } \\
\text { Fluorescence microscopy }\end{array}$ & [136] \\
\hline $\begin{array}{l}\text { Raw milk; Pasteurized } \\
\text { milk; Raw meat; } \\
\text { Ready-to-eat meat; } \\
\text { Seafood }\end{array}$ & Listeria spp. (spiked) & $\begin{array}{c}\text { Lis-16S-1 } \\
\text { (ACTGTTGTTAGAGAAG) } \\
\text { Lm-16S-2 } \\
\text { (TAGTACAAAGGGTCG) } \\
\text { Lm-16S-3 } \\
\text { (CGAATGATAAAGTGT) } \\
\text { Lm-16S-4 (CGCATGCCACGCTTT) } \\
\text { Liv-16S-5 (ACGCATGTCATCACT) } \\
\text { Fluorophore: FAM }\end{array}$ & $\begin{array}{l}\text { Enrichment: according to standard } \\
\text { procedures } \\
\text { Fixation: centrifugation }(2000 \times g, \\
5 \text { min), washed PBS, resuspended } \\
\text { in PBS, } 10 \mu \mathrm{L} \text { placed onto a } \\
\text { microscope coverslip, air-dried, } \\
\text { fixed with } 80 \% \text { ethanol ( } 15 \text { min) } \\
\text { Fluorescence microscopy }\end{array}$ & [137] \\
\hline $\begin{array}{l}\text { Powdered infant } \\
\text { formula }\end{array}$ & Salmonella spp. (spiked) & $\begin{array}{c}\text { 23S, DNA: Sal-3 } \\
\text { (AATCACTTCACCTACGTG) } \\
\text { 23S, DNA: Salm-63 } \\
\text { (GCTGCCTCCCGTAGGAGT) } \\
\text { PNA: Sal23S10 } \\
\text { (TAAGCCGGGATGGC) } \\
\text { PNA: SalPNA1873 } \\
\text { (AGGAGCTTCGCTTGC) } \\
\text { Fluorophore: AlexaFluor 594 }\end{array}$ & $\begin{array}{c}\text { Pre-enrichment: sterile distilled } \\
\text { water }\left(8 \mathrm{~h}, 37^{\circ} \mathrm{C}\right) \\
\text { Fixation: pelleted }(10,000 \times g, \\
5 \text { min), } 4 \% \text { paraformaldehyde }(1 \mathrm{~h}) \\
\text { Fluorescence microscopy }\end{array}$ & [138] \\
\hline
\end{tabular}


Table 4. Cont.

\begin{tabular}{|c|c|c|c|c|}
\hline Sample & Target Microorganisms & $\begin{array}{c}\text { Target Probe }\left(5^{\prime}-3^{\prime} \text { Sequence }\right) \text { and } \\
\text { Fluorophore }\end{array}$ & $\begin{array}{c}\text { Sample Prepara- } \\
\text { tion/Fixation/Observation } \\
\text { Method }\end{array}$ & References \\
\hline $\begin{array}{l}\text { Natural whey starters } \\
\text { for Parmigiano } \\
\text { Reggiano }\end{array}$ & $\begin{array}{c}\text { Lactobacillus helveticus, } \\
\text { Streptococcus thermophilus } \\
\text { (natural) }\end{array}$ & $\begin{array}{c}\text { 23S: Lbh1 } \\
\text { 23S: St4 } \\
\text { Fluorophore: FITC, Cy3 }\end{array}$ & $\begin{array}{l}\text { Bacterial removal: whey samples } \\
\text { washed twice in PBS, pellets } \\
\text { resuspended in PBS. } \\
\text { Fixation: } 4 \% \text { freshly prepared cold } \\
\text { paraformaldehyde }\left(1 \mathrm{~h}, 4^{\circ} \mathrm{C}\right) \\
\text { Fluorescence microscopy }\end{array}$ & [139] \\
\hline $\begin{array}{l}\text { Dairy starter cultures } \\
\text { (PROBAT-like cultures) }\end{array}$ & $\begin{array}{l}\text { Lactococcus lactis subsp. } \\
\text { cremoris, L. lactis subsp. } \\
\text { lactis, Leuconostoc spp. } \\
\text { (natural) }\end{array}$ & $\begin{array}{c}\text { 16S: CREM62 } \\
\text { (CCAATCTTCATCGCTCAA) } \\
\text { 16S: LAC62 } \\
\text { (CCAACCTTCAGCGCTCAA) } \\
\text { 16S: LEUC1026 } \\
\text { (CACTTTGTCTCCGAAGAG) } \\
\text { Fluorophore: Oregon Green }\end{array}$ & $\begin{array}{c}\text { Fixation: pure cultures and cleared } \\
\text { PROBAT cultures resuspended in } \\
\text { PBS; mixed with equal volume } \\
\text { ethanol ( } 96 \%) \\
\text { Flow cytometry; fluorescence } \\
\text { microscopy }\end{array}$ & [140] \\
\hline Dairy starter cultures & Leuconostoc spp. (natural) & $\begin{array}{c}\text { 16S: Leugen2 } \\
\text { (GGGCATTACAAACTCCC) } \\
\text { 16S: CHCC2114 } \\
\text { (ACTTCGTATCATGCGAC) } \\
\text { Fluorophore: Cy3, FITC }\end{array}$ & $\begin{array}{l}\text { Fixation: starter cultures } \\
\text { centrifuged ( } 5 \mathrm{~min}, 14,000 \times \mathrm{g} \text { ) and } \\
\text { washed in PBS; one volume of cell } \\
\text { suspension was mixed with three } \\
\text { volumes of freshly prepared cold } \\
\text { paraformaldehyde solution }(4 \% \text { in } \\
\text { PBS; } 4 \mathrm{C}, 16 \mathrm{~h}) \\
\text { Fluorescence microscopy }\end{array}$ & [141] \\
\hline Milk & $\begin{array}{c}\text { Enterobacteriaceae; } \\
\text { Pseudomonas spp. (spiked) }\end{array}$ & $\begin{array}{c}\text { 16S: Enterobacteriaceae } \\
\text { (TGCTCTCGCGAG- } \\
\text { GTCGCTTCTCTT) } \\
\text { 16S: Pseudomonas spp. } \\
\text { (GATCCGGACTACGATCGGTTT) } \\
\text { Fluorophore: } \text { FITC, Cy5 }\end{array}$ & $\begin{array}{c}\text { Milk clearing: } 0.5 \mu \mathrm{L} \\
\text { savinase }+100 \mu \mathrm{L} 0.1 \% \text { Triton } \\
\text { X-100 }+100 \mu \mathrm{L} \text { milk }\left(30^{\circ} \mathrm{C} \text {, }\right. \\
30 \mathrm{~min})+800 \mu \mathrm{L} 150 \mathrm{mM} \mathrm{NaCl} \\
\text { solution, centrifuged }(13,500 \times g, \\
\left.5 \text { min, } 20^{\circ} \mathrm{C}\right) \text {, resuspended with } \\
\text { PBS; sample filtered }(0.2 \mu \mathrm{m} \text { pore } \\
\text { size) } \\
\text { Colony formation: filter on } \\
\text { Standard Methods Agar }\left(37^{\circ} \mathrm{C}\right. \\
\text { (Enterobacteriaceae) or } 30^{\circ} \mathrm{C} \\
\text { (Pseudomonas spp.), } 3-5 \mathrm{~h}) \\
\text { Fixation: microcolonies } \\
\text { dehydrated by a filter paper } \\
\text { soaked with } 80 \% \text { ethanol (10 min, } \\
\text { RT), air-dried on a new filter paper. } \\
\text { Fluorescence microscopy }\end{array}$ & [142] \\
\hline Raw bovine milk & Helicobacter pylori (natural) & $\begin{array}{l}\text { 16S. Hpy-1 (CACACCTGACT- } \\
\text { GACTATCCCG) } \\
\text { Fluorophore: TAMRA }\end{array}$ & $\begin{array}{c}\text { Removal of particulate milk } \\
\text { components: milk mixed } 2 \% \\
\text { sodium citrate solution }(1 \mathrm{~min}, \\
\text { speed setting “ } 6 \text { " in a BagMixer), } \\
\text { centrifuged ( } 5000 \times g, 10 \mathrm{~min}, \\
\left.4{ }^{\circ} \mathrm{C}\right) \text {, pellets washed twice with } \\
2 \% \text { sodium citrate; resuspended in } \\
\text { PBS } \\
\text { Fixation: } 4 \% \text { paraformaldehyde } \\
\text { solution }\left(4{ }^{\circ} \mathrm{C}, 16 \mathrm{~h}\right) \\
\text { Fluorescence microscopy }\end{array}$ & [143] \\
\hline Ultra-heat-treated milk & $\begin{array}{l}\text { Bacillus cereus spores } \\
\text { (spiked) }\end{array}$ & $\begin{array}{c}\text { 16S: pB394 (ATGCGGTTCAAAAT- } \\
\text { GTTATCCGG } \\
\text { Fluorophore: Alexa488 }\end{array}$ & $\begin{array}{c}\text { Fat removal: } 25 \% \text { sodium } \\
\text { citrate + milk }(5 \mathrm{~min}, 200 \mathrm{rpm}), \\
\text { centrifuged }(15,000 \times g, 5 \mathrm{~min}), \\
\text { cream adhered to the wall } \\
\text { removed; pellet resuspended in } \\
\text { TSB + L-alanine + inosine }(1 \mathrm{~h}, \\
\left.37^{\circ} \mathrm{C}, 150 \mathrm{rpm}\right) \\
\text { Fixation: pelleted }(12,000 \mathrm{rpm}, \\
2 \text { min), } 4 \% \text { paraformaldehyde } \\
\text { (15 min) } \\
\text { Fluorescence microscopy }\end{array}$ & [144] \\
\hline
\end{tabular}


Table 4. Cont.

\begin{tabular}{|c|c|c|c|c|}
\hline Sample & Target Microorganisms & $\begin{array}{c}\text { Target Probe }\left(5^{\prime}-3^{\prime} \text { Sequence }\right) \text { and } \\
\text { Fluorophore }\end{array}$ & $\begin{array}{c}\text { Sample Prepara- } \\
\text { tion/Fixation/Observation } \\
\text { Method }\end{array}$ & References \\
\hline Milk & Pseudomonas spp. (spiked) & $\begin{array}{l}\text { 16S: Pseudomonas spp. } \\
\text { (GATCCGGACTACGATCGGTTT) } \\
\text { Fluorophore: TexasRed (TR), FITC }\end{array}$ & $\begin{array}{l}\text { Milk protein and fat removal: } \\
10 \mu \mathrm{L} \text { savinase }+100 \mu \mathrm{L} \text { milk } \\
\left(30^{\circ} \mathrm{C}, 30-45 \mathrm{~min}\right)+0.15 \mathrm{M} \mathrm{NaCl}, \\
\text { centrifuged }\left(10,000 \times g, 22^{\circ} \mathrm{C},\right. \\
5 \text { min), digested proteins and top } \\
\text { layer drawn off; bacterial pellet } \\
\text { suspended in hybridization buffer } \\
\text { Flow cytometry; fluorescence } \\
\text { microscopy }\end{array}$ & [145] \\
\hline Milk & Lactobacillus spp. (spiked) & $\begin{array}{c}\text { 16S, PNA: Lac663 } \\
\text { (ACATGGAGTTCCACT) } \\
\text { Fluorophore: AlexaFluor488 }\end{array}$ & $\begin{array}{l}\text { Fixation: milk pelleted }(10,000 \times g, \\
5 \mathrm{~min}), 4 \% \text { paraformaldehyde }(1 \mathrm{~h}) \\
\text { Fluorescence microscopy }\end{array}$ & [146] \\
\hline Skimmed milk & $\begin{array}{c}\text { Propionibacterium } \\
\text { freudenreichii, Lactococcus } \\
\text { lactis (spiked) }\end{array}$ & $\begin{array}{c}\text { 16S: GLO62 } \\
\text { (AAGGGCCTTACCGTCCGA) } \\
\text { 16S: PEU64 } \\
\text { (CAAGGGGCCTTACCGTCC) } \\
\text { 16S: PFX311 } \\
\text { (GGCACGTTCCTCACGTGT) } \\
\text { 16S: LactV5 } \\
\text { (GCTCCCTACATCTAGCAC) } \\
\text { Fluorophore: Cy3, Cy5 }\end{array}$ & $\begin{array}{c}\text { Fixation: sample centrifuged } \\
(12,000 \times g, 2 \mathrm{~min}) \text {; pellets washed } \\
\text { twice with PBS; pellet fixed in } \\
\text { solution of PBS/ice cold ethanol } \\
\left(12 \mathrm{~h}, 4^{\circ} \mathrm{C}\right) \\
\text { Fluorescence microscopy }\end{array}$ & [147] \\
\hline Milk & Pseudomonas spp. (spiked) & $\begin{array}{c}\text { 16S: } \text { P. putida probe } \\
\text { (TTGCCAGTTTTGGATGCAGT) } \\
\text { 16S: Pseudomonas spp. probe } \\
\text { (GATCCGGACTACGATCGGTT) } \\
\text { Fluorophore: Cy5 }\end{array}$ & $\begin{array}{l}\text { Fixation: CTC-stained cells in } \\
\text { paraformaldehyde (final } \\
\text { concentration: } 8 \%, 4^{\circ} \mathrm{C}, 1 \mathrm{~h} \text { ) } \\
\text { Fluorescence microscopy }\end{array}$ & [148] \\
\hline Wine & $\begin{array}{l}\text { Dekkera bruxellensis } \\
\text { (natural) }\end{array}$ & $\begin{array}{c}\text { PNA: BRE26S14 } \\
\text { Fluorophore: } \\
\text { 5(6)-carboxyfluorescein }\end{array}$ & $\begin{array}{l}\text { Pre-enrichment: wine samples } \\
\text { filtered }(0.45 \mu \mathrm{m} \text { pore size, HVLP } \\
\text { filter membranes; incubation (BSM, } \\
\left.30^{\circ} \mathrm{C}\right) \text {; grown colonies used } \\
\text { without fixation } \\
\text { Fluorescence microscopy }\end{array}$ & [149] \\
\hline Wine & $\begin{array}{l}\text { Lactic acid bacteria } \\
\text { (natural) }\end{array}$ & $\begin{array}{c}\text { 16S: Lbrev } \\
\text { (CATTCAACGGAAGCTCGTTC) } \\
\text { 16S: Lcoll } \\
\text { (CTTGATTTAACGGGATG) } \\
\text { 16S: Lcory } \\
\text { (GCTTCGGTCGACGTCAGT) } \\
\text { 16S: Lfarc } \\
\text { (AGCTTCAATCTTCAGGAT) } \\
\text { 16S: Lhilg (CAACTTCATTGAC- } \\
\text { CAAGACGCG) } \\
\text { 16S. Lmali (AAGCATTCGRT- } \\
\text { GAAAGTTTTG) } \\
\text { 16S: Lpara } \\
\text { (GTTCCATGTTGAATCTCGG) } \\
\text { 16S: Lzeae(5'- } \\
\text { TTCATCGACAAAACTC-3') } \\
\text { 16S: Ooeni } \\
\text { (5'-TAGTCATTGCCTCACTTCAC } \\
\text { CCGAA-3') } \\
\text { 16S: Pdamn } \\
\text { 16S: Pparv (5'- } \\
\text { (5'-GTTGAATCATCG') } \\
\text { ATAACAC-3') } \\
\text { CTAAAATCATCTCA } \\
\text { Fluorophore: rhodamine 6G, } \\
\text { 5(6)-carboxy-fluorescein-N- } \\
\text { hydroxysuccinimide ester, 6-FAM, } \\
\text { Alexa Fluor 350, 5(6)-carboxy- } \\
\text { tetramethylrhodamine-N- } \\
\text { hydroxysuccinimide } \\
\text { ester }\end{array}$ & $\begin{array}{l}\text { Bacterial removal: wine samples } \\
\text { filtered using a vacuum of } 6250 \\
\text { mbar on black polycarbonate } \\
\text { filters }(0.2 \mu \mathrm{m} \text { pore size }) \\
\text { Fixation: overlaying the filter twice } \\
\text { with PBS; } 96 \% \text { ethanol added } \\
(3 \mathrm{~min}, \mathrm{RT}) \text {; cell permeabilization } \\
\text { with lysozyme } \\
\text { Fluorescence microscopy }\end{array}$ & [150] \\
\hline
\end{tabular}


Table 4. Cont.

\begin{tabular}{|c|c|c|c|c|}
\hline Sample & Target Microorganisms & $\begin{array}{c}\text { Target Probe }\left(5^{\prime}-3^{\prime} \text { Sequence }\right) \text { and } \\
\text { Fluorophore }\end{array}$ & $\begin{array}{c}\text { Sample Prepara- } \\
\text { tion/Fixation/Observation } \\
\text { Method }\end{array}$ & References \\
\hline $\begin{array}{l}\text { White and red must } \\
\text { industrial fermentations }\end{array}$ & $\begin{array}{c}\text { Yeasts } \\
\text { (natural) }\end{array}$ & $\begin{array}{c}\text { 26S: Cst } \\
\text { 26S: Hgu } \\
\text { (CTCTATGGCGTTCTTC) } \\
\text { (CAATCCCAGCTAGCAGTAT) } \\
\text { 26S: Huv } \\
\text { (TCAATCCCGGCTAACAGTA) } \\
\text { 26S: Kma } \\
\text { (AGCTACAAAGTCGCCTTC) } \\
\text { 26S: Kth } \\
\text { (ATAGGACTAGACTCCTCG) } \\
\text { 26S: Pan } \\
\text { (GACAGGCAATATCAGCAGA) } \\
\text { 26S: Pme } \\
\text { (AGAGCTTCGCACGGCACC) } \\
\text { 26S: Sce } \\
\text { (TGACTTACGTCGCAGTCC) } \\
\text { 26S: Tde } \\
\text { (GCAGTATTTCTACAGGAT) } \\
\text { Fluorophore: FITC }\end{array}$ & $\begin{array}{c}\text { Colony preparation: yeast } \\
\text { counting on CRB medium; } 30 \\
\text { colonies picked for yeast } \\
\text { identification } \\
\text { Fixation: } 4 \% \text { paraformaldehyde } \\
\left(4 \mathrm{~h}, 4^{\circ} \mathrm{C}\right) \\
\text { Fluorescence microscopy }\end{array}$ & [151] \\
\hline Wine fermentation & $\begin{array}{l}\text { S. cerevisiae, Hanseniaspora } \\
\text { guilliermondii (spiked) }\end{array}$ & $\begin{array}{c}\text { 26S: } \text { S. cerevisiae } \\
\text { (CAATCCCAGCTAGCAGTAT) } \\
\text { 26S: H. guilliermondii } \\
\text { (TGACTTACGTCGCAGTCC) } \\
\text { Fluorophore: FITC }\end{array}$ & $\begin{array}{c}\text { Bacterial removal: samples } \\
\text { centrifuged }(5 \text { min, } 5000 \times g) \text {, cells } \\
\text { washed once with PBS } \\
\text { Fixation: } 4 \% \text { paraformaldehyde } \\
\left(3 \mathrm{~h}, 4{ }^{\circ} \mathrm{C} \text {, strong agitation }\right) \\
\text { Flow cytometry; fluorescence } \\
\text { microscopy }\end{array}$ & [152] \\
\hline Wine fermentations & $\begin{array}{l}\text { S. cerevisiae, Hanseniaspora } \\
\text { uvarum, Starmerella } \\
\text { bacillaris (spiked/natural) }\end{array}$ & $\begin{array}{c}\text { 26S: Cst } \\
\text { 26S: Hgu } \\
\text { (CTCTATGGCGTTCTTC) } \\
\text { (CAATCCCAGCTAGCAGTAT) } \\
\text { 26S: Huv } \\
\text { (TCAATCCCGGCTAACAGTA) } \\
\text { 26S: H8a } \\
\text { (TGAGAGGCCCAAGCCCAC) } \\
\text { 26S: H8b } \\
\text { (AGGTAATCCCAGTTGGTT) } \\
\text { 26S: H8b-Com } \\
\text { (AGGCAATCCCGGTTGGTT) } \\
\text { 26S: Sce } \\
\text { (TGACTTACGTCGCAGTCC) } \\
\text { 26S: Sba } \\
\text { (CTCCATGGCGCTCCTTTC) } \\
\text { Fluorophore: FITC }\end{array}$ & $\begin{array}{c}\text { Bacterial removal: samples } \\
\text { centrifuged (10,000 rpm, } 5 \mathrm{~min}) \text {, } \\
\text { resuspended in } 1 \times \text { PBS } \\
\text { Fixation: } 4 \% \text { paraformaldehyde } \\
\left(1 \mathrm{~h}, 4^{\circ} \mathrm{C}, 1000 \mathrm{rpm}\right) \\
\text { Flow cytometry; fluorescence } \\
\text { microscopy }\end{array}$ & [153] \\
\hline Wine fermentations & $\begin{array}{l}\text { S. cerevisiae, } H \text {. } \\
\text { guilliermondii (spiked) }\end{array}$ & $\begin{array}{c}\text { 26S: S. cerevisiae } \\
\text { (CAATCCCAGCTAGCAGTAT) } \\
\text { 26S: H. guilliermondii } \\
\text { (TGACTTACGTCGCAGTCC) } \\
\text { Fluorophore: FITC }\end{array}$ & $\begin{array}{c}\text { Bacterial removal: samples } \\
\text { centrifuged ( } 5000 \mathrm{rpm}, 5 \mathrm{~min}) \\
\text { resuspended in } 1 \times \mathrm{PBS} \\
\text { Fixation: } 4 \% \text { of paraformaldehyde } \\
\text { for }\left(4 \mathrm{~h}, 4{ }^{\circ} \mathrm{C}, 1000 \mathrm{rpm}\right) \text {; DAPI/PI } \\
\text { staining prior to fixation for } \\
\text { viability testing } \\
\text { Flow cytometry; fluorescence } \\
\text { microscopy }\end{array}$ & [154] \\
\hline Red and white wine & $\begin{array}{l}\text { Dekkera bruxellensis } \\
\text { (spiked) }\end{array}$ & $\begin{array}{c}\text { 26S: Dkb271 } \\
\text { (CCTTCCTCCTCTCTAGT) } \\
\text { Fluorophore: ATTO 647N }\end{array}$ & $\begin{array}{c}\text { Bacterial removal: cells recovered } \\
\text { via centrifugation, washed with } \\
\text { PBS } \\
\text { Fixation: absolute ethanol ( } 1 \mathrm{~h}, \mathrm{RT}) \\
\text { Flow cytometry; fluorescence } \\
\text { microscopy }\end{array}$ & [155] \\
\hline
\end{tabular}


Table 4. Cont.

\begin{tabular}{|c|c|c|c|c|}
\hline Sample & Target Microorganisms & $\begin{array}{c}\text { Target Probe }\left(5^{\prime}-3^{\prime} \text { Sequence) and }\right. \\
\text { Fluorophore }\end{array}$ & $\begin{array}{c}\text { Sample Prepara- } \\
\text { tion/Fixation/Observation } \\
\text { Method }\end{array}$ & References \\
\hline Beer & $\begin{array}{l}\text { P. cerevisiiphilus, Pectinatus } \\
\text { frisingensis } \\
\text { (spiked) }\end{array}$ & $\begin{array}{c}\text { 16S: Pf469 } \\
\text { (CATTCACTATACTTATTGGC) } \\
\text { 16S: Pc469 } \\
\text { (CATTCAATAGTGGTATTAAC), } \\
\text { 16S: Pc593 } \\
\text { (AAGATCCGCTTAGTCATCCG), } \\
\text { 16S: Pc640 } \\
\text { (AAGATGACCAGTTCGAATCC) } \\
\text { Fluorophore: FITC }\end{array}$ & $\begin{array}{c}\text { Bacterial removal: centrifugation } \\
(5 \text { min, } 10,000 \times g) \text {, suspended in } \\
\text { sterile PBS } \\
\text { Fixation: PBS }+99 \% \text { ethanol }(1: 1 ; \\
\quad 30 \text { min }) \\
\text { Fluorescence microscopy }\end{array}$ & [156] \\
\hline Vinegar & $\begin{array}{l}\text { Acetic acid bacteria } \\
\text { (natural) }\end{array}$ & $\begin{array}{c}\text { 16S: Komag } \\
\text { (GAACCTTTCGGGGTTAGTG) } \\
\text { Fluorophore: FITC }\end{array}$ & $\begin{array}{c}\text { Bacterial removal: centrifugation } \\
\left(2000 \times g, 4^{\circ} \mathrm{C}, 10 \mathrm{~min}\right), \text { washed } \\
\text { with PBS } \\
\text { Fixation: } 4 \% \text { paraformaldehyde } \\
\left(4{ }^{\circ} \mathrm{C}, 12 \mathrm{~h}\right) \\
\text { Flow cytometry }\end{array}$ & [157] \\
\hline $\begin{array}{c}\text { Glass, Polypropylene } \\
\text { Polyethylene, Polyvinyl } \\
\text { chloride, Copper, } \\
\text { Silicone rubber, Stainless } \\
\text { steel }\end{array}$ & $\begin{array}{c}\text { S. enterica/ } \\
\text { L. monocytogenes/E. coli } \\
\text { single, dual and tri-species } \\
\text { biofilms } \\
\text { (laboratory grown) }\end{array}$ & $\begin{array}{c}\text { 23S, PNA: SalPNA1873 } \\
\text { 16S, PNA: LmPNA1253 } \\
\text { (GACCCTTGTACTAT) } \\
\text { Fluorophore: Alexa594, Alexa488 }\end{array}$ & $\begin{array}{c}\text { Biofilm preparation: } 24-48 \mathrm{~h} \\
\text { biofilm formation on different } \\
\text { materials } \\
\text { Sample preparation: biofilm } \\
\text { coupons in distilled water; } \\
\text { sonicated for } 5 \mathrm{~s} \text { at } 25 \% \text { amplitude; } \\
\text { centrifugation }(10,000 \mathrm{rpm}, 5 \mathrm{~min}) \\
\text { Fixation: } 4 \% \text { paraformaldehyde for } \\
1 \mathrm{~h} \\
\text { Fluorescence microscopy; confocal } \\
\text { laser scanning microscopy }\end{array}$ & [158] \\
\hline $\begin{array}{l}\text { Polyvinyl chloride } \\
\text { coupons }\end{array}$ & H. pylori (natural) & $\begin{array}{c}\text { PNA: } \\
\text { (TAATCAGCACTCTAGCAA) } \\
\text { Fluorophore: carboxyfluorescein }\end{array}$ & $\begin{array}{l}\text { Sampling: semi-circular flow cells } \\
\text { containing PVC coupons placed in } \\
\text { a bypass of a drinking water } \\
\text { distribution system, sampling after } \\
\text { up to } 72 \mathrm{~d} \\
\text { Fixation: coupons in } 90 \% \text { ethanol, } \\
10 \mathrm{~min} \\
\text { Fluorescence microscopy }\end{array}$ & [159] \\
\hline Conveyor in brewery & Natural biofilm & $\begin{array}{c}\text { EUB338 } \\
\text { EUK502 } \\
\text { ARCH915 } \\
\text { ALF968 } \\
\text { BET42a } \\
\text { GAM42a } \\
\text { XAN818 } \\
\text { HGC69a } \\
\text { LGC-354A-C } \\
\text { CF319a } \\
\text { PLA46 } \\
\text { AG1427 } \\
\text { Ent183 } \\
\text { Pae997 } \\
\text { Hpae1 } \\
\text { Hpae2 } \\
\text { (GAAGGCACCAATCCATC) } \\
\text { (TGTCAAGGCCWGGTAAGG) } \\
\text { Fluorophore: not given }\end{array}$ & $\begin{array}{l}\text { Sample preparation: removal of } \\
\text { biofilms, lubricants, and } \\
\text { rubbed-off conveyor material } \\
\text { sampled with sterile spatula; } \\
\text { washing twice with sterilized } \\
\text { water and decane; centrifugation } \\
\text { to remove decane } \\
\text { Fixation: paraformaldehyde or } \\
\text { ethanol }\end{array}$ & [160] \\
\hline
\end{tabular}


Table 4. Cont.

\begin{tabular}{|c|c|c|c|c|}
\hline Sample & Target Microorganisms & $\begin{array}{c}\text { Target Probe }\left(5^{\prime}-3^{\prime} \text { Sequence) and }\right. \\
\text { Fluorophore }\end{array}$ & $\begin{array}{c}\text { Sample Prepara- } \\
\text { tion/Fixation/Observation } \\
\text { Method }\end{array}$ & References \\
\hline Stainless steel coupons & $\begin{array}{c}\text { Arcobacter brutzleri } \\
\text { Arcobacter cryaerophilus } \\
\text { Arcobacter skirrowii } \\
\text { C. jejuni } \\
\text { C. coli biofilms } \\
\text { (spiked) }\end{array}$ & $\begin{array}{c}\text { Arc94 } 4^{\mathrm{Cy} 3} \\
\text { (TGCGCCACTTAGCTGACA) } \\
\text { Catherm }{ }^{\mathrm{Cy} 3} \\
\text { (GCCCTAAGCGTCCTTCCA) } \\
\text { EUB338 }{ }^{\text {FAM }} \\
\text { (GCTGCCTCCCGTAGGAGT) } \\
\text { Fluorophore: Cy3, FAM }\end{array}$ & $\begin{array}{c}\text { Biofilm preparation: stainless steel } \\
\text { coupons in casein peptone } \\
\text { soymeal-peptone broth containing } \\
10^{7} \mathrm{cfu} / \mathrm{mL} \text { bacteria; culturing for } \\
78 \mathrm{~h} \text { at } 25^{\circ} \mathrm{C} \text { under aerobic or } \\
\text { microaerobic conditions } \\
\text { Sample preparation: coupons } \\
\text { wiped with sterile swabs; swabs } \\
\text { with biofilm shaken in PBS }(2 \mathrm{~min} \text {, } \\
\text { vortex); centrifugation }(16,500 \times g \text {, } \\
\left.5 \mathrm{~min}, 21^{\circ} \mathrm{C}\right) \\
\text { Fixation: } 2 \% \text { formaldehyde, } 24 \mathrm{~h} \text {, } \\
4^{\circ} \mathrm{C} \\
\text { Fluorescence microscopy }\end{array}$ & [161] \\
\hline
\end{tabular}

FISH DNA or PNA probes are used for biofilm characterization, and the analyzed biofilms are either natural biofilms or those formed under laboratory conditions. FISH was used by Almeida, Azevedo, Santos, Keevil, and Vieira [158] to characterize and quantify the biofilm formation of S. enterica, L. monocytogenes, and E. coli on different surfaces (e.g., glass, stainless steel) using PNA probes. Stainless steel was also used as a surface to capture biofilm formation of various Arcobacter species using FISH in a study by Šilhová, Mot'ková, Šilha, and Vytřasová [161]. Bragança, Azevedo, Simões, Keevil, and Vieira [159] screened natural biofilms in a drinking water distribution system for the occurrence of $H$. pylori using PNA-FISH and evaluated the composition of natural biofilms from conveyors in breweries.

In general, the analysis of solid and liquid food products by means of flow-FISH often requires additional sample preparation steps (Figure 2) [162]. The presence of a high amount of proteins and fats might disturb the hybridization of the probes and these may have to be removed. Unspecific proteinases, dilution with appropriate buffers, homogenization, centrifugation, and filtration steps are applied to sample liquid food products. Different sample preparation steps must be performed depending on whether only microorganisms from the surface or from the entire product are to be detected. Homogenization with buffers or nutrient broth is followed by several filtrations and/or centrifugation steps to remove larger particles. In the case of surface sampling, the use of adhesive tape showed promising results. Additionally, pre-enrichment steps might be necessary for low numbers of target microorganisms in the food product. However, it has to be taken into account that the sample preparation steps might impact microorganism detection [1].

\subsection{Flow-FISH in Water and Bioaerosols}

In addition to food products and food contact surfaces, Flow-FISH is also applied to water (Table 5) samples and bioaerosols (Table 6). Water samples were either spiked with the relevant microorganism or the composition of the natural load was investigated. Additionally, water samples were analyzed in regard to the occurrence of specific microorganisms. FISH was applied to tap water samples to detect E. coli [163], C. coli, and Mycobacterium avium $[164,165]$. However, most studies dealing with FISH for water samples have focused on seawater and lake water samples. Here, FISH methods with tyramide signal amplification and without tyramide signal amplification have been applied [166-174]. 
Table 5. FISH applications for microorganism detection in water samples.

\begin{tabular}{|c|c|c|c|c|}
\hline Sample & Target Microorganisms & $\begin{array}{c}\text { Target Probe }\left(5^{\prime}-3^{\prime} \text { Sequence }\right) \text { and } \\
\text { Fluorophore }\end{array}$ & $\begin{array}{c}\text { Sample } \\
\text { Preparation/Fixation/Observation } \\
\text { Method }\end{array}$ & References \\
\hline Water & $\begin{array}{l}\text { E. coli } \\
\text { (spiked) }\end{array}$ & $\begin{array}{c}\text { 16S: ES445 } \\
\text { (CTTTACTCCCTTCCTCCC) } \\
\text { Fluorophore: Су3 }\end{array}$ & $\begin{array}{l}\text { Fixation: formalin (final conc. } 2 \% \text { ) } \\
\text { Semi-automatically } \\
\text { polydimethylsiloxane-glass hybrid } \\
\text { microfluidic device; fluorescence } \\
\text { microscopy }\end{array}$ & [163] \\
\hline Tap water & C. coli (spiked) & $\begin{array}{l}\text { 16S, PNA: CJE195 } \\
\text { Fluorophore: TAMRA }\end{array}$ & $\begin{array}{c}\text { Bacterial removal: samples filtered } \\
\text { through a track etch black } \\
\text { membrane filter }(0.2 \mu \mathrm{m}) \\
\text { Fixation: smear air dried, gently } \\
\text { flamed; } 90 \% \text { ethanol }(10 \mathrm{~min}), \\
\text { air-dried } \\
\text { Fluorescence microscopy }\end{array}$ & [164] \\
\hline Water & $\begin{array}{l}\text { Mycobacterium avium } \\
\text { (spiked) }\end{array}$ & $\begin{array}{l}\text { 16S, PNA: MAV148 } \\
\text { (TGCGTCTTGAGGTCC) } \\
\text { Fluorophore: 6-FAM }\end{array}$ & $\begin{array}{c}\text { Bacterial removal: filtered through } \\
\text { membrane filter }(0.2 \mu \mathrm{m}) \text {; filter } \\
\text { shaking with } 6 \mathrm{~mL} \text { of the original } \\
\text { water filtrate and glass beads } \\
\text { Fixation: smear air dried, gently } \\
\text { flamed; } 90 \% \text { ethanol (10 min), } \\
\text { air-dried } \\
\text { Fluorescence microscopy }\end{array}$ & [165] \\
\hline Freshwater lake & $\begin{array}{c}\text { Microcystis aeruginosa } \\
\text { Planktothrix rubescens } \\
\text { Planktothrix agardhii } \\
\text { (spiked) }\end{array}$ & $\begin{array}{c}\text { Probes labeled with horseradish } \\
\text { peroxidase } \\
\text { 16S: EUB338 } \\
\text { (GCTGCCTCCCGTAGGAGT) } \\
\text { 16S: MICR3 (TCTGCCAGTTTCCAC- } \\
\text { CGCCTTTAGGT) } \\
\text { mcyA-mRNA: MCYA } \\
\text { (ATGAGCCGCCAATAAAACACTTT) } \\
\text { Fluorophore: FITC-labeled tyramides }\end{array}$ & $\begin{array}{c}\text { Sample preparation: filtration of } \\
\text { water } \\
\text { Fixation: } 1 \% \text { paraformaldehyde, } \\
15 \text { min, RT } \\
\text { Fluorescence microscopy }\end{array}$ & [166] \\
\hline $\begin{array}{l}\text { Lakes; } \\
\text { Oceans }\end{array}$ & Natural load & $\begin{array}{c}\text { 16S: EUB338 } \\
\text { (GCTGCCTCCCGTAGGAGT) } \\
\text { 16S: NON338 } \\
\text { (ACTCCTACGGGAGGCAGC) } \\
\text { 16S: ALF968 } \\
\text { (GGTAAGGTTCTGCGCGTT) } \\
\text { 23S: BET42a } \\
\text { (GCCTTCCCACTTCGTTT) } \\
\text { 23S: GAM42a } \\
\text { (GCCTTCCCACATCGTTT) } \\
\text { 16S: CF319a } \\
\text { (TGGTCCGTGTCTCAGTAC) } \\
\text { 16S: PLA886 } \\
\text { (GCCTTGCGACCATACTCCC) } \\
\text { 16S: ARCH915 } \\
\text { (GTGCTCCCCGCCAATTCCT) } \\
\text { Fluorophore: Cy3 }\end{array}$ & $\begin{array}{c}\text { Sample preparation: concentration } \\
\text { of water samples on white } \\
\text { polycarbonate filters }(0.2 \mu \mathrm{m} \text { pore } \\
\text { size) } \\
\text { Fixation: } 4 \% \text { paraformaldehyde, } \\
30 \text { min, RT } \\
\text { Fluorescence microscopy }\end{array}$ & [168] \\
\hline Seawater & Natural load & $\begin{array}{c}\text { 16S: EUB338 } \\
\text { (GCTGCCTCCCGTAGGAGT) } \\
\text { Fluorophore: Cy5 }\end{array}$ & $\begin{array}{c}\text { Sample preparation: large plankton } \\
\text { particles removed by gravity } \\
\text { filtration on } 10 \mu \mathrm{m} \text { mesh; gravity } \\
\text { filtration on } 3 \mu \mathrm{m} \text { polycarbonate } \\
\text { membranes } \\
\text { Fixation: } 2 \% \text { formaldehyde, } 60 \mathrm{~min}, \\
\text { dark, RT } \\
\text { Microfluidic flow cytometry }\end{array}$ & [167] \\
\hline Seawater & $\begin{array}{l}\text { Heterosigma akashiwo } \\
\text { (natural) }\end{array}$ & $\begin{array}{c}\text { Probes labeled with horseradish } \\
\text { peroxidase } \\
\text { HSIG 1451 } \\
\text { (CCCTCGGCAAGTCACAAT) } \\
\text { NONEUB338 } \\
\text { (ACTCCTACGGGAGGCAGC) } \\
\text { EUK1209 (GGGCATCACAGACCTG) } \\
\text { Fluorophore: not given }\end{array}$ & $\begin{array}{l}\text { Fixation: } 0.1 \% \text { formaldehyde, } 1 \mathrm{~h}, \mathrm{RT} \\
\text { Fluorescence microscopy; flow } \\
\text { cytometry }\end{array}$ & [170] \\
\hline
\end{tabular}


Table 5. Cont.

\begin{tabular}{|c|c|c|c|c|}
\hline Sample & Target Microorganisms & $\begin{array}{c}\text { Target Probe }\left(5^{\prime}-3^{\prime} \text { Sequence) and }\right. \\
\text { Fluorophore }\end{array}$ & $\begin{array}{c}\text { Sample } \\
\text { Preparation/Fixation/Observation } \\
\text { Method }\end{array}$ & References \\
\hline Seawater & $\begin{array}{c}\text { Marine bacteria (natural) } \\
\text { E. coli } \\
\text { (spiked) }\end{array}$ & $\begin{array}{c}\text { Probes labeled with horseradish } \\
\text { peroxidase } \\
\text { 16S: EUB338 } \\
\text { 16S: NONEUB338 } \\
\text { Fluorophore: Alexa488 labeled } \\
\text { tyramides }\end{array}$ & $\begin{array}{c}\text { Sample preparation: samples } \\
\text { pre-filtered on a } 3-\mu \text { m-diameter } \\
\text { pore-size membrane } \\
\text { Fixation: } 2 \% \text { paraformaldehyde, } 1 \mathrm{~h} \text {, } \\
\text { RT } \\
\text { Fluorescence microscopy; flow } \\
\text { cytometry }\end{array}$ & [171] \\
\hline Lake water & $\begin{array}{l}\text { Ultramicrobiota } \\
\text { (natural) }\end{array}$ & $\begin{array}{c}\text { Probes labeled with horseradish } \\
\text { peroxidase } \\
\text { 23S: BET42a } \\
\text { 16S: LD12-121 } \\
\text { 16S: NON338 } \\
\text { 16S: LD12-115 (CTGAACCACAAG- } \\
\text { GCAGATTCCCACAT) } \\
\text { Fluorophore: Fluorescein-labeled } \\
\text { tyramides } \\
\text { Anti-Fluorescein-HRP conjugate }\end{array}$ & $\begin{array}{c}\text { Sample preparation: samples } \\
\text { pre-filtered on a } 0.8-\mu \mathrm{m} \text {-diameter } \\
\text { pore-size membrane } \\
\text { Fixation: } 1.7 \% \text { paraformaldehyde, } \\
15 \text { min, } 4^{\circ} \mathrm{C} \text {, collected on filters } \\
\text { Fluorescence microscopy; flow } \\
\text { cytometry }\end{array}$ & [172] \\
\hline Seawater & $\begin{array}{l}\text { Bacterioplankton } \\
\text { (natural) }\end{array}$ & $\begin{array}{c}\text { Probes labeled with horseradish } \\
\text { peroxidase } \\
\text { 23S: BET42a } \\
\text { (GCCTTCCCACTTCGTTT) } \\
\text { 16S: CF319a } \\
\text { (TGGTCCGTGTCTCAGTAC) } \\
\text { 16S: EUB338 } \\
\text { (GCTGCCTCCCGTAGGAGT) } \\
\text { 16S: NONEUB338 } \\
\text { (ACTCCTACGGGAGGCAGC) } \\
\text { 16S: ALF968 } \\
\text { (GGTAAGTTCTGCGCGTT) } \\
\text { 23S: GAM42a } \\
\text { (GCCTTCCCACATCGTTT) } \\
\text { ROS537 (CAACGCTAACCCCCTCC) } \\
\text { OM43-162 } \\
\text { (ATGCGGCATTAGCTAACC) } \\
\text { Nso190 (CGATCCCCTGCTTTTCTCC) } \\
\text { Nso1225 } \\
\text { (CGCCATTGTATTACGTGTGA) } \\
\text { SAR86-1245 } \\
\text { (TTAGCGTCCGTCTGTAT) } \\
\text { Fluorophore: Alexa546, Alexa488 }\end{array}$ & $\begin{array}{c}\text { Fixation: } 2 \% \text { formaldehyde, }<24 \mathrm{~h}, \\
4{ }^{\circ} \mathrm{C} \text {, collected on filters } \\
\text { Fluorescence microscopy; flow } \\
\text { cytometry }\end{array}$ & [173] \\
\hline Seawater & $\begin{array}{c}\text { E. coli } \\
\text { (spiked) }\end{array}$ & $\begin{array}{c}\text { 16S: Eco541 } \\
\text { (CCGATTAACGCTTGCACC) } \\
\text { 16S: Eco1482 } \\
\text { (TACGACTTCACCCCAGTC) } \\
\text { Fluorophore: FITC }\end{array}$ & $\begin{array}{c}\text { Sample preparation: spiked and } \\
\text { nonspiked seawater filtered through } \\
15 \mu \mathrm{m} \text { membrane; centrifugation } \\
\left(4000 \times g, 4{ }^{\circ} \mathrm{C}, 15 \mathrm{~min}\right) \text { two times } \\
\text { Fixation: } 4 \% \text { cold paraformaldehyde, } \\
4^{\circ} \mathrm{C}, 16-18 \mathrm{~h} \\
\text { Fluorescence microscopy; flow } \\
\text { cytometry }\end{array}$ & [174] \\
\hline Seawater & Vibrio cholerae & $\begin{array}{c}\text { TaqMan probe } \\
\text { (TCAACCGATGCGATTGCCCAAGA) } \\
\text { Fluorophore: Alexa } 488\end{array}$ & $\begin{array}{c}\text { Fixation: } 4 \% \text { cold paraformaldehyde, } \\
4{ }^{\circ} \mathrm{C} \text {, overnight } \\
\text { Fluorescence microscopy; flow } \\
\text { cytometry }\end{array}$ & [169] \\
\hline
\end{tabular}

Table 6. FISH applications for microorganism detection in air and aerosols.

\begin{tabular}{|c|c|c|c|c|}
\hline Sample & Target Microorganisms & $\begin{array}{c}\text { Target Probe }\left(5^{\prime}-3^{\prime} \text { Sequence) and }\right. \\
\text { Fluorophore }\end{array}$ & $\begin{array}{c}\text { Sample Prepara- } \\
\text { tion/Fixation/Observation } \\
\text { Method }\end{array}$ & References \\
\hline $\begin{array}{l}\text { Laboratory-generated } \\
\text { bioaerosols; } \\
\text { Native bioaerosols in } \\
\text { swine barn }\end{array}$ & $\begin{array}{l}\text { P. aeruginosa } \\
\text { E. coli } \\
\text { (spiked) } \\
\text { Natural load }\end{array}$ & $\begin{array}{c}\text { 16S: TR-EUB } \\
\text { (GCTGCCTCCCGTAGGAGT) } \\
\text { fl-PSMg (CCTTCCTCCCAACTT) } \\
\text { 16S: TR-NotEUB } \\
\text { (ACTCCTACGGGAGGCAGC } \\
\text { Fluorophore: Texas Red, fluorescein }\end{array}$ & $\begin{array}{l}\text { Sampling: } 30 \mathrm{~min} \\
\text { sampling time, } 12.5 \mathrm{~L} / \mathrm{min} \\
\text { flow rate into } 20 \mathrm{~mL} \text { of } \\
\text { medium or } 20 \mathrm{~L} / \mathrm{min} \text { into } \\
8 \mathrm{~mL} \text { of medium } \\
\text { Fixation: } 1 \% \\
\text { formaldehyde for } \\
\text { microscopy; } 4 \% \\
\text { paraformaldehyde for } \\
\text { flow cytometry } \\
\text { Fluorescence microscopy; } \\
\text { flow cytometry }\end{array}$ & [80] \\
\hline
\end{tabular}


Table 6. Cont.

\begin{tabular}{|c|c|c|c|c|}
\hline Sample & Target Microorganisms & $\begin{array}{c}\text { Target Probe }\left(5^{\prime}-3^{\prime} \text { Sequence) and }\right. \\
\text { Fluorophore }\end{array}$ & $\begin{array}{c}\text { Sample Prepara- } \\
\text { tion/Fixation/Observation } \\
\text { Method }\end{array}$ & References \\
\hline $\begin{array}{l}\text { Air in } \\
\text { a sow breeding barn }\end{array}$ & Natural load & $\begin{array}{c}\text { EUB mix } \\
\text { NONEUB } \\
\text { ALF968 } \\
\text { ARCH915 } \\
\text { BET42a } \\
\text { CF319a+b } \\
\text { CLOST I } \\
\text { GAM42a } \\
\text { HGC69a } \\
\text { LGC354abc } \\
\text { PF2 } \\
\text { SAU } \\
\text { SRB385 } \\
\text { STR } \\
\text { Fluorophore: FLUOS, Cy3 }\end{array}$ & $\begin{array}{l}\text { Sampling: filtering air } \\
\text { onto a } 25-\mathrm{mm} \text {-thick glass } \\
\text { fiber filter, } 1-4 \mathrm{~d} \text {; average } \\
\text { air flow of } 200 \mathrm{~m}^{3} / \mathrm{h} ; \\
\text { bioaerosols eluted into a } \\
\text { sealed container by } \\
\text { washing the filters in } \\
\text { sterile filtered tap water } \\
\text { Fluorescence microscopy }\end{array}$ & [175] \\
\hline $\begin{array}{l}\text { Bioaerosols in swine } \\
\text { buildings }\end{array}$ & Natural load & $\begin{array}{c}\text { 16S: fl-Univ } \\
\text { (ACGGGCGTCGTGT(AG)C) } \\
\text { 16S: fl-EUB } \\
\text { (GCTGCCTCCCGTAGGAGT) } \\
\text { 16S: cy-EUK (ACCAGACTTGCCCTCC) } \\
\text { 16S: fl-PSMg (CCTTCCTCCCAACTT) } \\
\text { 16S: fl-NotEUB } \\
\text { (ACT-CCT-ACG-GGAGGCAGC) } \\
\text { Fluorophore: Fluorescein, Cy3 }\end{array}$ & $\begin{array}{l}\text { Sampling: AGI sampler } \\
\text { with } 12.5 \mathrm{~L} / \mathrm{min} \text { flow rate } \\
\text { for } 40 \mathrm{~min} \\
\text { Fixation: } 4 \% \text { cold } \\
\text { paraformaldehyde }\end{array}$ & [176] \\
\hline $\begin{array}{l}\text { Air from a compost plant } \\
\text { treating }\end{array}$ & Natural load & POD-labeled probes & $\begin{array}{l}\text { Sampling: MD8 air } \\
\text { samplers with } 3.0 \mu \mathrm{m} \\
\text { gelatin filters; filters } \\
\text { incubated on top of CASO } \\
\text { agar }\left(30^{\circ} \mathrm{C}, 24-48 \mathrm{~h}\right) \\
\text { Chemiluminescence } \\
\text { detection }\end{array}$ & [177] \\
\hline Aerosols of water & $\begin{array}{l}\text { Legionella pneumophila } \\
\text { serogroup } 1 \text { strain } \\
\text { (Spiked/natural) }\end{array}$ & $\begin{array}{c}\text { 16S: LEG705 } \\
\text { (CTGGTGTTCCTTCCGATC) } \\
\text { Fluorophore: carbocyanine }\end{array}$ & $\begin{array}{l}\text { Sampling: impaction onto } \\
\text { agar (Andersen sampler); } \\
\text { impingement into liquid } \\
\text { (SKC Biosampler (Arelco); } \\
\text { filtration (collectron MD8 } \\
\text { (Sartorius) } \\
\text { Fixation: } 3.7 \% \\
\text { formaldehyde, } 30 \text { min } \\
\text { Fluorescence microscopy }\end{array}$ & [178] \\
\hline
\end{tabular}

For air-related applications, the natural load of bioaerosols in swine barns and buildings was successfully characterized using FISH $[80,175,176]$. Additionally, Legionella pneumophila in water aerosols were accurately detected using FISH [178]. Neef and Kämpfer [177] demonstrated the highly specific detection of microorganisms in bioaerosols from compost plant, performing the treatment within two working days using FISH, compared to weeks using cultivation techniques.

Even though FCM and flow-FISH have potential as innovative and fast monitoring and detection methods within the food and bioindustries, there are still food-related limitations.

\section{General and Food-Related Limitations for Specific and Non-Specific Methods}

\subsection{Instrumental Limitations}

According to a review by $\mathrm{Wu}$ et al. [39], challenges and limitations of bacterial analysis with FCM are mainly related to instrumental background noise or background from the sheath or sample fluid. With conventional FCM, it is thus difficult to distinguish small-sized bacteria $(<0.5 \mu \mathrm{m})$ from background signals by means of light scattering alone. A study by Zacharias et al. [83] concluded that FCM worked well for monoculture but 
had difficulties with mixed populations. This leads to the assumption that the final interpretation of FCM data could be challenging for unknown microbial populations present in food products. It is also well-known that a specific cell concentration is required for optimal staining and cell counts. Cell aggregates in particular can lead to underestimated cell counts, as two or more particles might be considered one large particle by the electronic system [179]. This coincidence occurs more frequently at cell concentrations $>2.5 \times$ $10^{6} \mathrm{~mL}^{-1}\left(\sim 1000-1400\right.$ events s$\left.^{-1}\right)$. This can be reduced by using a low cell concentration or flow rate and through disaggregation via sonication $[17,180]$. According to a review by Wilkinson [40], most FCM protocols work best with $10^{5}-10^{6}$ cells $\mathrm{mL}^{-1}$, whereas in a study by [181], $10^{4}-10^{8}$ cells $\mathrm{mL}^{-1}$ showed optimal results for the live/dead analysis of a mixture bacteria population. They also argued that beyond these limits, false-positive readings were significant in association with interference from the sheath fluid or electronic system. In most of the studies summarized in Section 5 and Tables 1 and 2, a cell concentration of $10^{4}-10^{7}$ cells $\mathrm{mL}^{-1}$ was suggested. Therefore, samples either need to be concentrated or diluted before FCM analysis.

\subsection{Hazardous and Toxic Substances for FCM and FISH Applications}

Another remaining challenge is the use of hazardous and toxic fluorescent dyes, as they may pose health and safety risks. As discussed in Sections 3.2 and 3.3, TCC or viability assessments are the most straightforward FCM assays, often performed with SYTO 9 or SYTO 9 and PI, respectively. Stiefel, Schmidt-Emrich, Maniura-Weber, and Ren [182] critically assessed the binding properties of those two dyes. In their study, it was concluded that SYTO 9 showed ineffective binding properties to intact Gram-negative cells, and also bleaching of SYTO 9 was reported. In comparison, PI staining can result in unwanted signals, also called background fluorescence, due to fluorescence in the unbound form. A study by Rosenberg, Azevedo, and Ivask [183] concluded that PI staining could underestimate the cell viability of adherent cells, as in biofilms, as extracellular nucleic acids outside intact cell membranes were stained red (PI), while at the same time, intracellular nucleic acids were stained green (SYTO 9).

Moreover, for a comprehensive viability assessment, the sole use of DNA-intercalating dyes (such as SG1 and PI or SYTO 9 and PI) is not sufficient, whereas assessments of esterase or respiratory activity are recommended in addition [59,83]. In contrast, a study by Kennedy et al. [53] further indicated that the detection of esterase activity and membrane potential, measured with a PI-calcein acetoxymethyl ester (calcein-AM) mix and $\mathrm{DiOC}_{2}(3)$, respectively, could have resulted in false-positive events after physiochemical treatment of samples with heat and chemicals. These findings lead to the conclusion that the selection of fluorescent dyes has to be performed individually for each experiment.

Regarding safety, EtBr [184], propidium monoazide, PI [185], SG1 [186], lactofuchsin [187], and TO [188] are some examples of synthetic dyes that pose a health risk to humans and other organisms, as well as to the environment, after waste disposal. They were previously reported as being carcinogenic, toxic, or at a minimum, strongly allergenic. Furthermore, fluorescent dyes are also expensive.

For the hybridization step required for FISH methods, toxic and potential teratogens such as formamide are commonly used. As cell permeabilization is affected by the Gram characteristics of the microorganisms and also by the bacterial growth phase, while applying permeabilization treatments, cell integrity has to be maintained and cell loss lysis has to be avoided $[106,162]$. The specificity of the oligonucleotide probes determines the reliability and accuracy of the FISH method. Since the stringency of the applied protocol is directly correlated with the specificity of the probes, the stringency of the hybridization buffer and wash solution has to be considered to allow the proper annealing of probes to the target site. To adjust the stringency, formamide and sodium chloride are used, and in general high-stringency hybridization in combination with similar or lower-stringency washing is applied to obtain higher specificity [162]. However, for formamide, specific safety measures and precautionary steps are required. 
Therefore, the necessity of the development of safer and more sustainable methods is arising [189]. Non-toxic, economic, and eco-friendly stains were previously discussed as a safer choice than the widely-used ones and these thus have future potential for viability or Gram staining $[185,187,190,191]$. The use of alternative substrates is further discussed as a new approach in Section 6.

\subsection{Limitations of Traditional Flow-FISH Protocols}

Specificity, sensitivity, and test speed, as well as economic aspects, play essential roles when considering the routine monitoring of food safety using flow-FISH [162]. Several challenges or limitations of FISH methods have to be taken into account. The first challenge is the food matrix itself. Due to strong background and autofluorescence signals, the food matrix is a critical influencing parameter for FISH methods, even though PCR-based methods are more biased by the matrix than FISH methods [162,192]. The detection limit of FISH methods is also a limitation. Unfiltered samples showed a detection limit of $10^{5} \mathrm{CFU} / \mathrm{mL}$ on slides, but $10^{3}-10^{4} \mathrm{CFU} / \mathrm{mL}$ have also been given as detection limits. However, the detection limits reveal the necessity to include pre-enrichment steps to fulfill the requirements to be comparable to standard detection methods [1,98]. Pre-enrichment steps also overcome the weak fluorescence signals of classic rRNA-targeted FISH. Lowfluorescence signals are attributed to a low ribosome content in metabolically inactive or slowly growing cells in environmental samples or insufficient cell permeability to allow the penetration of the probes into the cells [106].

\subsection{Interference with Food Matrices}

In addition to the selection of appropriate fluorescent dyes, food matrix molecules, i.e., milk proteins [193], debris in wine [70], or any particles showing auto-fluorescence can interfere with the fluorescent dyes and impact the assay. Complex formulated food such as ready-to-eat meals offer additional challenges, as DNA-intercalating cell viability stains can non-specifically bind to, e.g., food flavorings containing DNA or RNA [194]. According to [71], probiotic drinks were suspended in buffer media and filtered ( $20 \mu \mathrm{m}$ filter) to avoid biases due to food matrix particles. To exclude debris from wine samples, the work by Malacrinò et al. [70] used prior centrifugation, and additional washing steps. To eliminate proteins and lipids present in milk, the working group of Gunasekera et al. [178] treated their samples with either proteinase K or savinase. Bunthof [72] applied a milk-clearing solution, resulting in the flocculation and coalescence of milk micelles and the lysis of somatic cells. With this approach, they increased the particle size of interfering cells to make their removal easier.

\subsection{Challenges for Rapid Bioaerosol Detection}

There are additional challenges to overcome for the fast detection and monitoring of air-borne microbes within food and agricultural environments. Depending on the environment, air samples often have to be concentrated, but the recovery rate of concentrated samples via centrifugation or filtration has been reported to be highly variable [195]. As already mentioned in Section 3.3, Day et al. [77] tested the applicability of two flow cytometer systems for the differentiation of air-borne $P$. infestans spores to pollen and other fungal spores. Different evaluation strategies such as multiple gating, the use of FSC, SSC, and autofluorescence measurement need to be applied to distinguish between FCM histograms for pollen, fungal spores, and P. infestans. Possible reasons for the complexity of air-related measures include the high similarity of significant background events and, depending on the sampling location, low cell concentrations (i.e., $10^{2} \mathrm{CFU} \mathrm{m}^{-3}$ in the indoor air of homes) [80]. A clear and reliable distinction between background and bacterial events, as is already available for water analysis, must be accomplished [49]. Furthermore, the lack of published work on this topic $[196,197]$ indicates that fast FCM detection for air-borne microbes has not yet been successful carried out. We believe that adapted sampling strategies that are compatible with FCM measurements are required, as well as specifically designed 
buffer solutions, and instrumental adaptations to overcome the high background signals. However, an adapted online air-sampling and FCM analysis chain could be of interest for the rapid detection of air-borne particles.

\section{Strategies to Overcome Limitations and to Improve Detection Methods 6.1. Alternative Non-Hazardous Stains and Solvents to Improve Safety}

Depending on the detection target and study aim, alternative fluorescent substrates could replace synthetic dyes to increase environmental and human safety and to lower costs. With alternative staining, this article refers to the use of substances that present one or more of the following characteristics: non-allergenic, non-toxic (also including noncytotoxic characteristics), noncarcinogenic, cost-effective, environmentally friendly, or biodegradable substrates. To give some applicable examples of alternative staining, a study by Vujanovic et al. [187] suggested fruit extracts for the cell wall staining of pathogenic Fusarium species via fluorescent microscopy. In their study, the highest fluorescence intensity was obtained by cranberry and currant extracts. Cell wall staining is typically used for the quantitative analysis of morphological or development studies but has also been proposed to have the potential for physiological research, as the cell wall structure adapts to physiological and environmental states [198]. It is also worth mentioning that Kurutos et al. [188] designed non-cytotoxic monomethine cyanine dyes for the microscopical fluorescent staining of chromosomes from human cell lines and could replace TO with this new staining approach. They found that the cyanine-based dye was $100 \times$ less toxic, showed a $5 \times$ higher photostability, and a higher (>800-fold) fluorescent intensity than TO. The present study will not further address staining methods for human cells, but aims to present the universal applicability of alternative staining methods that have been previously published. Outside of the field of fluorescence microscopy and flow cytometry, safer staining choices are becoming widely accepted in agarose gel staining and real-time PCR assays. Zhu et al. [199] reported the applicability of synthesized non-toxic and cost-effective copper nanoclusters for DNA staining, instead of EtBr, in gel electrophoresis. Furthermore, a study by Haines et al. [186] discussed the applicability of four commercially available replacements for SG1 and EtBr for agarose gel staining. Non-toxic and non-mutagenic characteristics were reported for the nucleic acid stains GelGreen ${ }^{\mathrm{TM}}$ and RedSafe ${ }^{\mathrm{TM}}$. Moreover, GelRed ${ }^{\mathrm{TM}}$ and Diamond ${ }^{\mathrm{TM}}$ Nucleic Acid Dye displayed weak mutagenic properties and toxic and mutagenic properties at stock concentrations, respectively. In contrast to this study, Sayas et al. [184] reported that both GelRed ${ }^{\mathrm{TM}}$ and RedSafe ${ }^{\mathrm{TM}}$ are toxic and mutagenic for S. cerevisiae, with RedSafe, however, being the safest dye. Furthermore, SYTOX Green, CellTox Green, and EvaGreen were previously found to be non-cytotoxic and cell impermeant when investigated with fluorescence microscopy [200]. According to a study by Tashyreva, Elster, and Billi [201], SYTOX Green was effectively used to visualize membrane-comprised cells of cyanobacteria when using fluorescent microscopy, with the minimal effective staining concentration ranging between 0.2 and $0.3 \mu \mathrm{m}$, and the significantly highest amount of stained cells was investigated after 90 min of incubation. Another innovative staining method for fluorescence microscopy was developed by Lin et al. [185], who designed carbon dots from L. plantarum LLC-605 exopolysaccharides, namely, CDs-EPS605, for live/dead analysis. The exopolysaccharides were purified, and quantum dots were fabricated via simple hydrothermal carbonization. The quantum dots were characterized as eco-friendly and cheap in production, and further showed negligible cytotoxicity, good fluorescence emission properties, as well as photostability. To conclude, a study by Kotenkova, Bataeva, Minaev, and Zaiko [202] recently assessed the potential of EvaGreen for flow cytometrical viability analysis of L. monocytogenes ATCC 13932. Their study reported signals in the green and red fluorescence spectra, indicating viable as well as dead cells with EvaGreen staining. However, as EvaGreen is cell-impermeant, DMSO was used to permeabilize the cell membrane, and thus the permeability of EvaGreen was influenced by the DMSO composition and the cell type used. Like EvaGreen, most of these non-toxic dyes, e.g., GelRed ${ }^{\mathrm{TM}}$, GelGreen ${ }^{\mathrm{TM}}$ [186], or SYTOX Green [201], are cell- 
impermeant and thus have potential as PI replacements. Their use instead of SG1 or EtBr replacements for flow cytometrical assays, however, requires an additional pre-treatment step, such as DMSO, to permeabilize the cell membranes. Interestingly, this was the only study found in relation to flow cytometry applications.

However, pretreatment steps are also required for flow-FISH protocols. Hybridization protocols require the use of the toxic solvent formamide for the reliable annealing of oligonucleotide probes to the target site, and studies are being conducted to replace formamide with non-toxic substances and still to achieve reliable annealing of the probes to the target sequence. Matthiesen and Hansen [203] revealed promising results using ethylene carbonate in non-toxic concentrations instead of formamide for tissue FISH, whereas Kalinka, My, and Achrem [204] and Golczyk [205] successfully substituted formamide with ethylene carbonate in plant FISH. Urea was used as a formamide alternative for the detection of gene expression in diverse animal species [206]. Aistleitner et al. [207] used urea as a formamide substitute for bacterial FISH and showed that the same specificity and similar signal intensities for the probes used in this study could be achieved after urea hybridization in comparison to hybridizations performed with formamide.

The lack of studies, however, underlines that this topic remains largely neglected for cytometry assays. We propose that alternative staining and hybridization procedures are crucial to maintaining safety for food and bioindustry applications in the long run.

\subsection{PEF-Assisted FCM and Flow-FISH Approaches}

The use of non-toxic alternative substrates, shorter incubation times, and increased fluorescence intensity signals are required to optimize FCM as a monitoring and detection tool for the food industry and the bioindustry. The permeabilization of cells could help to improve these three criteria, as impermeant (staining) molecules can immediately pass the cell wall; thus, no incubation time with the staining solution is needed, and fluorescence intensity will be increased if more staining molecules can enter the cells. For cell permeabilization, well-known pre-treatment steps include ethanol fixation, RNase digestion, and enzymatic cell wall digestion with, for instance, pepsin, proteinase $K$, or snailase treatment. Zhang and others (2018) compared three different methods for yeast cell permeabilization, including snailase digestion, DMSO, and electroporation, as pretreatments for yeast DNA staining. They suggested that the use of DMSO $\left(50 \%(v / v)\right.$ for $20 \mathrm{~min}$ at $\left.60{ }^{\circ} \mathrm{C}\right)$ is the best method to improve PI staining in different basidiomycetous yeasts, as it is quick, simple, and cheap. In their study, however, they did not show any data observed using electroporation pre-treatment. However, DMSO is also discussed to show at least low mutagenicity [208] and toxicity [209]. An electroporation-based pretreatment with pulsed electric fields (PEFs) might be a safe, as well as a quick and cost-efficient, alternative. Electroporation of the microbial cell membrane is induced by generating high-intensity electric fields $\left(\mathrm{kV} \mathrm{cm}^{-1}\right)$ for repetitive short time periods $(\mu \mathrm{s})$. The formation of pores can either be reversible or irreversible, depending on the interplay of various conditions such as treatment intensity, electrical conductivity, and electrode configuration [62]. Permanent pores can result in membrane integrity loss and uncontrolled molecule transfer through microbial cell membranes [210]. Currently, many researchers are focusing on the use of PEF to permeabilize microbial cell membranes of, for instance, microalgae [211], yeast [212], and bacteria cells [213] to extract valuable substances. A recent review by Martínez, Delso, Álvarez, and Raso [214] summarized the advantages of PEF in comparison to chemical and physical cell permeabilization or disruption methods. They argued that PEF is energetically efficient, non-destructive, highly selective, easy to scale up, as well as low in operational costs, has no thermal effects, and requires only a short processing time. Furthermore, PEF showed inactivation effects in different food matrices, such as in milk [58,215] and fruit [216], and vegetable juices [217] are typically analyzed using FCM. Although there are many studies on PEF-assisted extraction and FCM characterization of PEF-induced damage, there are only a few studies within the food sector on the use of electroporation for channeling molecules into cells [218]. However, loading cells with 
small molecules is commonly used within the medical area, e.g., in electrochemotherapy or gene electrotransfer $[219,220]$. This PEF-assisted FCM detection method could be used to load microbial cells with a non-toxic nucleic acid stain for TCC analysis, to be used as a first indicator of microbial contamination. However, all these applications (extracting molecules, loading cells with molecules, and the inactivation of cells) are based on the permeabilization of the cell membrane by means of PEFs. For some applications, i.e., for cultivation after FCM analysis or for cell sorting, reversible electroporation is essential to maintain the metabolically active state of the cells. This is, however, already challenging with single-strain populations in suspensions, as a population contains microbes within different growth states and the homogeneity of PEF treatment is still challenging. A study by Vaessen, Timmermans, Tempelaars, Schutyser, and Den Besten [221] demonstrated two different staining protocols-first with PI only, and second with a double-staining method prior to and after PEF treatment using PI and SYTOX Green-to analyze PEF permeabilized L. plantarum cells. With the double staining method, they were able to find a larger reversible permeabilized fraction, with $40 \%$. Their study demonstrates that the reversible permeabilization of microbial cells is still challenging, as up to $100 \%$ of the cells should be targeted to obtain representative data about quantitative microbial cell counts. Another study by Zand, Schottroff, Schoenher, et al. [222] suggested a rapid single-staining method with SYTOX Green and additional gating to describe intermediate cellular states of E. coli, such as sublethal effects, induced by PEF.

Moreover, the improved permeabilization of cell membranes is of interest for alternative staining methods and during FISH to allow the penetration of probes into the cells. To date, permeabilization has been realized enzymatically or chemically, but there is always the risk of cell lysis [106]. Additionally, concerning a possible fast, automated detection method applied in routine (online) food analysis, chemical substances are undesirable in a production plant, as they could contaminate the products. Furthermore, commonly used dehydration steps, which lead to an increase in the probe uptake, are unsuitable for rapid automatic detection due to the need for elaborate sample preparation. Fröhling, Nettmann, Jäger, Knorr, and Schlüter [223] showed that the use of PEFs to permeabilize E. coli cells increased the hybridization rate, and a reliable detection using flow cytometry was possible. Electroporation was also successfully used by Ruark-Seward, Davis, and Sit [224] for the FISH analysis of nematodes, and a reduction in time and specimen losses, and increased hybridization efficiency was achieved, showing the potential of electroporation for cell permeabilization in FISH methods. These successful FISH-related applications lead to the assumption that PEF pre-treatment will potentially also benefit alternative staining methods for quantitative FCM approaches.

\subsection{Optimized Flow-FISH Concepts}

Various modifications of classical FISH procedures are described in the literature. Volpi and Bridger [225] assembled an excellent overview of FISH techniques. Since the classical FISH methods often result in low fluorescence signals, several improved FISH methods are available to overcome these drawbacks. Double labeling of oligonucleotide probes (DOPE)-FISH is based on the use of double-labeled probes (at the $5^{\prime}$ and $3^{\prime}$ ends), which doubles the fluorescence signals and enables the simultaneous detection of six microbial populations [207,226]. Using catalyzed reporter deposition (CARD)-FISH, a 26- to 41-fold-higher sensitivity than that of standard FISH is achieved [110,227]. Additionally, it was shown that CARD-FISH could detect mRNAs of virulence factors in $L$. monocytogenes [112]. However, it has to be considered that the enzyme-labeled probes require the higher permeability of the cell membranes [227,228]. The two-step hybridization chain reaction (HCR)-FISH is a radical-free alternative to CARD-FISH, which is performed without formaldehyde fixation, with the advantage that DNA quality and genome amplification are not impaired. HCR-FISH was used in combination with FACS to enrich bacteria for genomic analysis [229]. Improvements of FISH using RNase-H-assisted rolling circle amplification enabled the visualization of mRNA expression at the single-cell level 
and, combined with meta-analysis, allowed researchers to gain insights into the role of individual microorganisms in the microbiota [230]. Batani, Bayer, Böge, Hentschel, and Thomas [231] developed a Live-FISH protocol in combination with FACS, which allowed the isolation and culturing of targeted bacteria. It is suggested that the method might have the potential to enhance the culturing of new microorganisms from diverse environments.

\subsection{Improvements of FCM-Based Bioaerosol Detection}

According to the reviews of Chen and Li [196] and Yoo et al. [197], FCM in combination with fluorescent techniques is a potential tool for the fast quantitative detection of air-borne microbes $\left(\sim 1000\right.$ cells s$\left.^{-1}\right)$, apart from qPCR or bioaerosol mass spectrometry, but it is rarely used for this purpose. The following recent findings underline the potential of innovative FCM strategies for bioaerosol quantification. Choi, Kang, and Jung [232] designed an integrated microchip flow cytometer, a so-called micro-optofluidic platform, for the realtime detection and quantification of air-borne cells, and coupled this with a BioSampler ${ }^{\circledR}$, a liquid-type particle collection setup, for the continuous sampling of airborne particles. Compared to microscopical investigations and colony counts, they were able to quantify the overall particle concentration within the air. They could distinguish E. coli, B. subtilis, and S. epidermidis bioaerosols from abiotic air debris when stained with SYTO82. Chang, Ting, and Horng [233] tested and compared three different liquid-based sampling techniques, including the cyclonic-based Coriolis ${ }^{\circledR} \mu$ Air Sampler, the BioStage ${ }^{\circledR}$ Single-Stage Impactor, and the BioSampler ${ }^{\circledR}$, in an animal farm, as well as a public library. Within that study, the BioSampler ${ }^{\circledR}$ showed the highest efficiency in collecting fungal aerosols, as assessed based on colony counts. There is no literature combining the Coriolis ${ }^{\circledR} \mu$ Air Sampler or the BioStage ${ }^{\circledR}$ Sampler with FCM to quantify air-borne microbes. In another work, Choi, Hong, Kim, and Jung [234] developed a liquid-based continuous microfluidic sampling device, the MicroSampler, for the real-time size-selective sampling of bioaerosols. The MicroSampler even showed good recovery of airborne S. epidermidis cells compared to

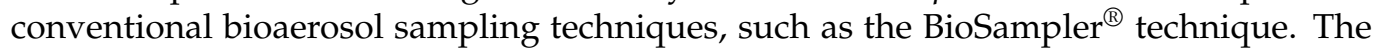
integration of a liquid-based sampler into an optimized FCM detection technique could have potential for future bioaerosol characterization within the food and bioindustries.

\section{Conclusions and Future Research Needs}

To summarize, it can be stated that FCM has been successfully used to detect and monitor microorganisms in water samples and was included in the Swiss guidelines for drinking water analysis in 2012 (SLMB, 2012). Moreover, FCM and flow-FISH are promising tools for the detection, monitoring, and characterization of microbes within the food industry and the bioindustry. Even though methodical improvements and innovative techniques are available and have demonstrated the potential of FISH for the detection of food pathogens and the potential of FCM for physiological targets, FCM and FISH are not routinely used to analyze and monitor microbial contamination of liquid and solid food products. Furthermore, the combination of FISH and flow cytometry (flow-FISH) has not gained considerable interest in relation to the detection of microorganisms in food production areas to date. State-of-the-art FCM protocols still show significant limitations, including (1) time-consuming or complex sample preparations and/or staining procedures; (2) the use of toxic substances that pose a risk for human health as well as their carry-over into the system; (3) instrumental drawbacks; (4) their limits of detection, especially for FISH assays; and (5) biases due to interferences with food matrices. Moreover, (6) challenges related to the analysis of airborne particles need to be tackled (6). Aside from these aspects, it has to be stated that the equipment's price and accessibility for food and bioprocessing labs is still limited. Future studies should focus on potential optimization strategies for FCM and FISH protocols, as well as on the development of automated lab-on-chip solutions.

To allow for rapid online and inline detection and monitoring within the food industry, non-hazardous alternative fluorochromes could be applied instead of toxic ones to avoid contamination of the analytical and production environment and risks for human health 
and safety. For the use of nontoxic fluorochromes, however, proper sample pretreatment steps must be implemented in order to maintain the performance of the analysis. PEF shows high potential as a pretreatment method, as it is non-destructive, no residues are generated, and has only low operational costs, as well as a short process time. It should be noted that the possibility of reversible permeabilization is of great importance for some applications in order to leave the cell physiology unaffected. PEF is not suitable as a pre-treatment step, for instance, if the effects of cleaning and disinfection on microbial cells are to be monitored, as PEF affects cell physiology. In contrast, for FISH, irreversible electroporation has been successfully applied as a permeabilization tool to increase the hybridization rate and speed up the analysis. Nevertheless, future research is necessary to overcome the heterogeneity of PEF and to validate the proposed PEF-assisted FCM detection approach. Combining FCM-based analysis with liquid-based sampling tools would also allow the detection and monitoring of airborne particles, as well as liquid and solid matrices.

Author Contributions: E.Z., A.F., O.S. and H.J. contributed to the study structure. E.Z. contributed to writing the FCM-based sections, as well as the introductory sections, and A.F. contributed to writing the FISH-related sections. C.S., M.Z.-P., O.S. and H.J. proof-read the manuscript. All authors have read and agreed to the published version of the manuscript.

Funding: This research was funded by the Austrian Research Promotion Agency, grant number 866346 New strategies for decontamination and aseptic processing considering manufacturing and building ser-vices engineering.

Institutional Review Board Statement: Not applicable.

Informed Consent Statement: Not applicable.

Conflicts of Interest: The authors declare no conflict of interest.

\section{Nomenclature}

$\begin{array}{ll}\text { CARD } & \text { Catalyzed reporter deposition } \\ \text { CTC } & \text { 5-cyano-2,3-ditolyl tetrazolium chloride } \\ \text { cFDA } & \text { Arboxyfluorescein diacetate } \\ \text { DiOC }_{2}(3) & \text { 3,3'-Diethyloxacarbocyanine Iodide } \\ \text { DiBA-C }_{4}(3) & \text { Bis-(1,3-Dibutylbarbituric Acid)Trimethine Oxonol } \\ \text { DPH } & \text { 1,6-Diphenyl-1,3,5-hexatriene } \\ \text { DOPE } & \text { Double Labeling of Oligonucleotide Probes } \\ \text { ICC } & \text { Intact cell count } \\ \text { ELISA } & \text { Enzyme-linked immunosorbent assay } \\ \text { EtBr } & \text { Ethidium bromide } \\ \text { FCM } & \text { Flow cytometry } \\ \text { FISH } & \text { Fluorescence in situ hybridization } \\ \text { FFS } & \text { Forward scatter } \\ \text { FDA } & \text { Fluorescin diacetate } \\ \text { FACS } & \text { Fluorescence-activated cell sorters } \\ \text { HCR } & \text { Hybridization chain reaction } \\ \text { LNA } & \text { Locked nucleic acids } \\ \text { PNA } & \text { Peptide nucleic acids } \\ \text { PCR } & \text { Polymerase chain reaction } \\ \text { PD } & \text { Photodiodes } \\ \text { PMT } & \text { Photomultiplier tubes } \\ \text { PI } & \text { Propidium iodide } \\ \text { PEF } & \text { Pulsed electric fields } \\ \text { SSC } & \text { Side scatter } \\ \text { SG1 } & \text { SYBR }{ }^{\circledR} \text { Green } \\ \text { TO } & \text { Thiazole orange } \\ \text { TCC } & \text { Total cell count } \\ \text { VBNC } & \text { Viable but non-culturable } \\ \end{array}$




\section{References}

1. Rohde, A.; Hammerl, J.A.; Appel, B.; Dieckmann, R.; Al Dahouk, S. FISHing for bacteria in food-A promising tool for the reliable detection of pathogenic bacteria? Food Microbiol. 2015, 46, 395-407. [CrossRef]

2. Havelaar, A.H.; Brul, S.; De Jong, A.; De Jonge, R.; Zwietering, M.H.; Ter Kuile, B.H. Future challenges to microbial food safety. Int. J. Food Microbiol. 2010, 139, S79-S94. [CrossRef]

3. Juzwa, W.; Duber, A.; Myszka, K.; Bialas, W.; Czaczyk, K. Identification of microbes from the surfaces of food-processing lines based on the flow cytometric evaluation of cellular metabolic activity combined with cell sorting. Biofouling 2016, 32, 841-851. [CrossRef]

4. Lelieveld, H.L.M.; Holah, J.; Gabric, D. Handbook of Hygiene Control in the Food Industry; Elsevier Science: Amsterdam, The Netherlands, 2016.

5. Wang, R. Biofilms and meat safety: A mini-review. J. Food Prot. 2019, 82, 120-127. [CrossRef]

6. Weber, M.; Liedtke, J.; Plattes, S.; Lipski, A. Bacterial community composition of biofilms in milking machines of two dairy farms assessed by a combination of culture-dependent and -independent methods. PLoS ONE 2019, 14, e0222238. [CrossRef]

7. Hameed, S.; Xie, L.; Ying, Y. Conventional and emerging detection techniques for pathogenic bacteria in food science: A review. Trends Food Sci. Technol. 2018, 81, 61-73. [CrossRef]

8. Marušić, A. Food safety and security: What were favourite topics for research in the last decade? J. Glob. Health 2011, 1, 72-78. [PubMed]

9. Pepe, T.; De Dominicis, R.; Esposito, G.; Ventrone, I.; Fratamico, P.M.; Cortesi, M.L. Detection of Campylobacter from poultry carcass skin samples at slaughter in Southern Italy. J. Food Prot. 2009, 72, 1718-1721. [CrossRef]

10. Rohde, A.; Hammerl, J.A.; Al Dahouk, S. Detection of foodborne bacterial zoonoses by fluorescence in situ hybridization. Food Control 2016, 69, 297-305. [CrossRef]

11. WHO. WHO Estimates of the Global Burden of Foodborne Diseases: Foodborne Disease Burden Epidemiology Reference Group 2007-2015; World Health Organization: Geneva, Switzerland, 2015.

12. Ge, B.; Meng, J. Advanced technologies for pathogen and toxin detection in foods: Current applications and future directions. JALA J. Assoc. Lab. Autom. 2009, 14, 235-241. [CrossRef]

13. Rajapaksha, P.; Elbourne, A.; Gangadoo, S.; Brown, R.; Cozzolino, D.; Chapman, J. A review of methods for the detection of pathogenic microorganisms. Analyst 2019, 144, 396-411. [CrossRef] [PubMed]

14. Velusamy, V.; Arshak, K.; Korostynska, O.; Oliwa, K.; Adley, C. An overview of foodborne pathogen detection: In the perspective of biosensors. Biotechnol. Adv. 2010, 28, 232-254. [CrossRef] [PubMed]

15. Ricke, S.C.; Feye, K.M.; Chaney, W.E.; Shi, Z.; Pavlidis, H.; Yang, Y. Developments in rapid detection methods for the detection of foodborne campylobacterin the United States. Front. Microbiol. 2019, 10, 3280. [CrossRef] [PubMed]

16. Wei, Q.Y.; Wang, X.M.; Sun, D.W.; Pu, H.B. Rapid detection and control of psychrotrophic microorganisms in cold storage foods: A review. Trends Food Sci. Technol. 2019, 86, 453-464. [CrossRef]

17. Safford, H.R.; Bischel, H.N. Flow cytometry applications in water treatment, distribution, and reuse: A review. Water Res. 2019, 151, 110-133. [CrossRef]

18. Kennedy, D.; Wilkinson, M.G. Application of flow cytometry to the detection of pathogenic bacteria. Curr. Issues Mol. Biol. 2017, 23, 21-38. [CrossRef]

19. Dias, G.; Rathnayaka, U. Fluorescence in situ hybridization (FISH) in food pathogen detection. Int. J. Mol. Biol. 2018, 3, 143-149. [CrossRef]

20. Law, J.W.-F.; Ab Mutalib, N.-S.; Chan, K.-G.; Lee, L.-H. Rapid methods for the detection of foodborne bacterial pathogens: Principles, applications, advantages and limitations. Front. Microbiol. 2015, 5, 770. [CrossRef]

21. Beneduce, L.; Gatta, G.; Bevilacqua, A.; Libutti, A.; Tarantino, E.; Bellucci, M.; Troiano, E.; Spano, G. Impact of the reusing of food manufacturing wastewater for irrigation in a closed system on the microbiological quality of the food crops. Int. J. Food Microbiol. 2017, 260, 51-58. [CrossRef]

22. Dzieciol, M.; Schornsteiner, E.; Muhterem-Uyar, M.; Stessl, B.; Wagner, M.; Schmitz-Esser, S. Bacterial diversity of floor drain biofilms and drain waters in a Listeria monocytogenes contaminated food processing environment. Int. J. Food Microbiol. 2016, 223, 33-40. [CrossRef] [PubMed]

23. Magaña, S.; Schlemmer, S.M.; Davidson, G.R.; Ryser, E.T.; Lim, D.V. Laboratory and pilot-scale dead-end ultrafiltration concentration of sanitizer-free and chlorinated lettuce wash water for improved detection of Escherichia coli O157:H7. J. Food Prot. 2014, 77, 1260-1268. [CrossRef]

24. Wagner, M.; Stessl, B. Sampling the food processing environment: Taking up the cudgel for preventive quality management in food processing environments. In Listeria Monocytogenes. Methods in Molecular Biology (Methods and Protocols); Jordan, K.F.E., Wagner, M., Eds.; Springer: Berlin/Heidelberg, Germany, 2014; Volume 1157, pp. 275-283.

25. Berrang, M.E.; Frank, J.F. Generation of airborne Listeria innocua from model floor drains. J. Food Prot. 2012, 75 , $1328-1331$. [CrossRef] [PubMed]

26. Brown, K.; Wray, S. Control of airborne contamination in food processing. In Hygiene in Food Processing; Elsevier: Amsterdam, The Netherlands, 2014; pp. 174-202.

27. Faille, C.; Cunault, C.; Dubois, T.; Bénézech, T. Hygienic design of food processing lines to mitigate the risk of bacterial food contamination with respect to environmental concerns. Innov. Food Sci. Emerg. Technol. 2018, 46, 65-73. [CrossRef] 
28. Fink, R.; Oder, M.; Stražar, E.; Filip, S. Efficacy of cleaning methods for the removal of Bacillus cereus biofilm from polyurethane conveyor belts in bakeries. Food Control 2017, 80, 267-272. [CrossRef]

29. Khatoon, Z.; McTiernan, C.D.; Suuronen, E.J.; Mah, T.-F.; Alarcon, E.I. Bacterial biofilm formation on implantable devices and approaches to its treatment and prevention. Heliyon 2018, 4, e01067. [CrossRef]

30. Costerton, J.W. Bacterial biofilms: A common cause of persistent infections. Science 1999, 284, 1318-1322. [CrossRef] [PubMed]

31. Silva, V.O.; Soares, L.O.; Silva Junior, A.; Mantovani, H.C.; Chang, Y.F.; Moreira, M.A.S. Biofilm formation on biotic and abiotic surfaces in the presence of antimicrobials by Escherichia coli isolates from cases of bovine mastitis. Appl. Environ. Microbiol. 2014, 80, 6136-6145. [CrossRef] [PubMed]

32. Zand, E.; Pfanner, H.; Domig, K.J.; Sinn, G.; Zunabovic-Pichler, M.; Jaeger, H. Biofilm-Forming Ability of Microbacterium lacticum and Staphylococcus capitis Considering Physicochemical and Topographical Surface Properties. Foods 2021, 10, 611. [CrossRef] [PubMed]

33. Rajwar, A.; Srivastava, P.; Sahgal, M. Microbiology of fresh produce: Route of contamination, detection methods, and remedy. Crit. Rev. Food Sci. Nutr. 2016, 56, 2383-2390. [CrossRef]

34. Jacxsens, L.; Uyttendaele, M.; Luning, P.; Allende, A. Food safety management and risk assessment in the fresh produce supply chain. IOP Conf. Ser. Mater. Sci. Eng. 2017, 193, 012020. [CrossRef]

35. Lopez-Galvez, F.; Gil, M.I.; Andujar, S.; Allende, A. Suitability of centrifuge water for detecting the presence of Escherichia coli versus finished fresh-cut lettuce testing. Food Microbiol. 2019, 84, 103271. [CrossRef] [PubMed]

36. Comas-Riu, J.; Rius, N. Flow cytometry applications in the food industry. J. Ind. Microbiol. Biotechnol. 2009, 36, 999-1011. [CrossRef]

37. Paparella, A.; Serio, A.; Chaves, C. Flow cytometry applications in food safety studies. Flow Cytom.-Recent Perspect. 2012, 69-102. [CrossRef]

38. Veal, D.A.; Deere, D.; Ferrari, B.; Piper, J.; Attfield, P.V. Fluorescence staining and flow cytometry for monitoring microbial cells. J. Immunol. Methods 2000, 243, 191-210. [CrossRef]

39. Wu, L.N.; Wang, S.; Song, Y.Y.; Wang, X.; Yan, X.M. Applications and challenges for single-bacteria analysis by flow cytometry. Sci. China-Chem. 2016, 59, 30-39. [CrossRef]

40. Wilkinson, M.G. Flow cytometry as a potential method of measuring bacterial viability in probiotic products: A review. Trends Food Sci. Technol. 2018, 78, 1-10. [CrossRef]

41. Díaz, M.; Herrero, M.; García, L.; Quirós, C. Application of flow cytometry to industrial microbial bioprocesses. Biochem. Eng. J. 2010, 48, 385-407. [CrossRef]

42. Allegra, S.; Berger, F.; Berthelot, P.; Grattard, F.; Pozzetto, B.; Riffard, S. Use of Flow Cytometry To Monitor Legionella Viability. Appl. Environ. Microbiol. 2008, 74, 7813. [CrossRef] [PubMed]

43. Nielsen, T.H.; Sjøholm, O.R.; Sørensen, J. Multiple physiological states of a Pseudomonas fluorescens DR54 biocontrol inoculant monitored by a new flow cytometry protocol. FEMS Microbiol. Ecol. 2009, 67, 479-490. [CrossRef]

44. Carrillo, M.G.; Ferrario, M.; Guerrero, S. Effectiveness of UV-C light assisted by mild heat on Saccharomyces cerevisiae KE 162 inactivation in carrot-orange juice blend studied by flow cytometry and transmission electron microscopy. Food Microbiol. 2018, 73, 1-10. [CrossRef]

45. Laflamme, C.; Lavigne, S.; Ho, J.; Duchaine, C. Assessment of bacterial endospore viability with fluorescent dyes. J. Appl. Microbiol. 2004, 96, 684-692. [CrossRef]

46. Rault, A.; Bouix, M.; Béal, C. Fermentation pH Influences the Physiological-State Dynamics of Lactobacillus bulgaricus CFL1 during pH-Controlled Culture. Appl. Environ. Microbiol. 2009, 75, 4374-4381. [CrossRef] [PubMed]

47. Tracy, B.P.; Gaida, S.M.; Papoutsakis, E.T. Flow cytometry for bacteria: Enabling metabolic engineering, synthetic biology and the elucidation of complex phenotypes. Curr. Opin. Biotechnol. 2010, 21, 85-99. [CrossRef] [PubMed]

48. Bunthof, C.J.; van den Braak, S.; Breeuwer, P.; Rombouts, F.M.; Abee, T. Rapid Fluorescence Assessment of the Viability of Stressed Lactococcus lactis. Appl. Environ. Microbiol. 1999, 65, 3681-3689. [CrossRef]

49. Favere, J.; Buysschaert, B.; Boon, N.; De Gusseme, B. Online microbial fingerprinting for quality management of drinking water: Full-scale event detection. Water Res. 2020, 170, 115353. [CrossRef]

50. Winson, M.K.; Davey, H.M. Flow cytometric analysis of microorganisms. Methods 2000, 21, 231-240. [CrossRef] [PubMed]

51. Liu, X.; Lendormi, T.; Le Fellic, M.; Lemée, Y.; Lanoisellé, J.-L. Hygienization of mixed animal by-product using pulsed electric field: Inactivation kinetics modeling and recovery of indicator bacteria. Chem. Eng. J. 2019, 368, 1-9. [CrossRef]

52. Azevedo, N.F.; Jardim, T.; Almeida, C.; Cerqueira, L.; Almeida, A.J.; Rodrigues, F.; Keevil, C.W.; Vieira, M.J. Application of flow cytometry for the identification of Staphylococcus epidermidis by peptide nucleic acid fluorescence in situ hybridization (PNA FISH) in blood samples. Antonie Van Leeuwenhoek 2011, 100, 463-470. [CrossRef] [PubMed]

53. Kennedy, D.; Cronin, U.P.; Piterina, A.; Wilkinson, M.G. Heat and chemical treatments affect the viability, morphology, and physiology of Staphylococcus aureus and its subsequent antibody labeling for flow cytometric analysis. Appl. Environ. Microbiol. 2019, 85, e01006-19. [CrossRef]

54. Barros, C.P.; Pires, R.P.S.; Guimarães, J.T.; Abud, Y.K.D.; Almada, C.N.; Pimentel, T.C.; Sant'Anna, C.; De-Melo, L.D.B.; Duarte, M.C.K.H.; Silva, M.C.; et al. Ohmic heating as a method of obtaining paraprobiotics: Impacts on cell structure and viability by flow cytometry. Food Res. Int. 2021, 140, 110061. [CrossRef] 
55. Braschi, G.; Patrignani, F.; Siroli, L.; Lanciotti, R.; Schlueter, O.; Froehling, A. Flow Cytometric Assessment of the Morphological and Physiological Changes of Listeria monocytogenes and Escherichia coli in Response to Natural Antimicrobial Exposure. Front. Microbiol. 2018, 9, 2783. [CrossRef]

56. Fröhling, A.; Baier, M.; Ehlbeck, J.; Knorr, D.; Schlüter, O. Atmospheric pressure plasma treatment of Listeria innocua and Escherichia coli at polysaccharide surfaces: Inactivation kinetics and flow cytometric characterization. Innov. Food Sci. Emerg. Technol. 2012, 13, 142-150. [CrossRef]

57. Fröhling, A.; Wienke, M.; Rose-Meierhofer, S.; Schlüter, O. Improved method for mastitis detection and evaluation of disinfectant efficiency during milking process. Food Bioprocess Technol. 2010, 3, 892-900. [CrossRef]

58. Jaeger, H.; Schulz, A.; Karapetkov, N.; Knorr, D. Protective effect of milk constituents and sublethal injuries limiting process effectiveness during PEF inactivation of Lb. rhamnosus. Int. J. Food Microbiol. 2009, 134, 154-161. [CrossRef]

59. Schenk, M.; Raffellini, S.; Guerrero, S.; Blanco, G.A.; Alzamora, S.M. Inactivation of Escherichia coli, Listeria innocua and Saccharomyces cerevisiae by UV-C light: Study of cell injury by flow cytometry. LWT-Food Sci. Technol. 2011, 44, 191-198. [CrossRef]

60. Tamburini, S.; Ballarini, A.; Ferrentino, G.; Moro, A.; Foladori, P.; Spilimbergo, S.; Jousson, O. Comparison of quantitative PCR and flow cytometry as cellular viability methods to study bacterial membrane permeabilization following supercritical $\mathrm{CO}_{2}$ treatment. Microbiology 2013, 159, 1056-1066. [CrossRef]

61. Teixeira, P.; Fernandes, B.; Silva, A.M.; Dias, N.; Azeredo, J. Evaluation by flow cytometry of Escherichia coli viability in lettuce after disinfection. Antibiotics 2020, 9, 14. [CrossRef] [PubMed]

62. Zand, E.; Schottroff, F.; Steinacker, E.; Mae-Gano, J.; Schoenher, C.; Wimberger, T.; Wassermann, K.J.; Jaeger, H. Advantages and limitations of various treatment chamber designs for reversible and irreversible electroporation in life sciences. Bioelectrochemistry 2021, 141, 107841. [CrossRef] [PubMed]

63. Fröhling, A.; Schlüter, O. Flow cytometric evaluation of physico-chemical impact on Gram-positive and Gram-negative bacteria. Front. Microbiol. 2015, 6, 939. [CrossRef]

64. Khan, M.M.T.; Pyle, B.H.; Camper, A.K. Specific and Rapid Enumeration of Viable but Nonculturable and Viable-Culturable Gram-Negative Bacteria by Using Flow Cytometry. Appl. Environ. Microbiol. 2010, 76, 5088-5096. [CrossRef]

65. Mao, C.; Xue, C.; Wang, X.; He, S.; Wu, L.; Yan, X. Rapid quantification of pathogenic Salmonella Typhimurium and total bacteria in eggs by nano-flow cytometry. Talanta 2020, 217, 121020. [CrossRef]

66. Yu, M.X.; Wu, L.N.; Huang, T.X.; Wang, S.; Yan, X.M. Rapid detection and enumeration of total bacteria in drinking water and tea beverages using a laboratory-built high-sensitivity flow cytometer. Anal. Methods 2015, 7, 3072-3079. [CrossRef]

67. Coronel-Leon, J.; Lopez, A.; Espuny, M.J.; Beltran, M.T.; Molinos-Gomez, A.; Rocabayera, X.; Manresa, A. Assessment of antimicrobial activity of $\mathrm{N}$-alpha-lauroyl arginate ethylester (LAE (R)) against Yersinia enterocolitica and Lactobacillus plantarum by flow cytometry and transmission electron microscopy. Food Control 2016, 63, 1-10. [CrossRef]

68. Barer, M.R.; Gribbon, L.T.; Harwood, C.R.; Nwoguh, C.E. The viable but non-culturable hypothesis and medical bacteriology. Rev. Med Microbiol. 1993, 4, 183-191. [CrossRef]

69. Schottroff, F.; Fröhling, A.; Zunabovic-Pichler, M.; Krottenthaler, A.; Schlüter, O.; Jäger, H. Sublethal Injury and Viable but Non-culturable (VBNC) State in Microorganisms During Preservation of Food and Biological Materials by Non-thermal Processes. Front. Microbiol. 2018, 9, 2773. [CrossRef] [PubMed]

70. Malacrinò, P.; Zapparoli, G.; Torriani, S.; Dellaglio, F. Rapid detection of viable yeasts and bacteria in wine by flow cytometry. J. Microbiol. Methods 2001, 45, 127-134. [CrossRef]

71. Maukonen, J.; Alakomi, H.L.; Nohynek, L.; Hallamaa, K.; Leppamaki, S.; Matto, J.; Saarela, M. Suitability of the fluorescent techniques for the enumeration of probiotic bacteria in commercial non-dairy drinks and in pharmaceutical products. Food Res. Int. 2006, 39, 22-32. [CrossRef]

72. Bunthof, C.J.; Abee, T. Development of a flow cytometric method to analyze subpopulations of bacteria in probiotic products and dairy starters. Appl. Environ. Microbiol. 2002, 68, 2934-2942. [CrossRef] [PubMed]

73. Fröhling, A.; Durek, J.; Schnabel, U.; Ehlbeck, J.; Bolling, J.; Schlüter, O. Indirect plasma treatment of fresh pork: Decontamination efficiency and effects on quality attributes. Innov. Food Sci. Emerg. Technol. 2012, 16, 381-390. [CrossRef]

74. Ma, Z.; Bumunang, E.W.; Stanford, K.; Bie, X.; Niu, Y.D.; McAllister, T.A. Biofilm formation by shiga toxin-producing Escherichia coli on stainless steel coupons as affected by temperature and incubation time. Microorganisms 2019, 7, 95. [CrossRef] [PubMed]

75. Besmer, M.D.; Epting, J.; Page, R.M.; Sigrist, J.A.; Huggenberger, P.; Hammes, F. Online flow cytometry reveals microbial dynamics influenced by concurrent natural and operational events in groundwater used for drinking water treatment. Sci. Rep. 2016, 6, 38462. [CrossRef]

76. Cao, R.; Wan, Q.; Tan, L.; Xu, X.; Wu, G.; Wang, J.; Xu, H.; Huang, T.; Wen, G. Evaluation of the vital viability and their application in fungal spores' disinfection with flow cytometry. Chemosphere 2021, 269, 128700. [CrossRef] [PubMed]

77. Day, J.P.; Kell, D.B.; Griffith, G.W. Differentiation of Phytophthora infestans sporangia from other airborne biological particles by flow cytometry. Appl. Environ. Microbiol. 2002, 68, 37-45. [CrossRef]

78. Farhat, N.; Kim, L.H.; Vrouwenvelder, J.S. Online characterization of bacterial processes in drinking water systems. NPJ Clean Water 2020, 3, 16. [CrossRef]

79. Koch, C.; Harnisch, F.; Schröder, U.; Müller, S. Cytometric fingerprints: Evaluation of new tools for analyzing microbial community dynamics. Front. Microbiol. 2014, 5, 273. [CrossRef] [PubMed] 
80. Lange, J.L.; Thorne, P.S.; Lynch, N. Application of flow cytometry and fluorescent in situ hybridization for assessment of exposures to airborne bacteria. Appl. Environ. Microbiol. 1997, 63, 1557-1563. [CrossRef]

81. Prest, E.I.; Hammes, F.; Kotzsch, S.; van Loosdrecht, M.C.M.; Vrouwenvelder, J.S. Monitoring microbiological changes in drinking water systems using a fast and reproducible flow cytometric method. Water Res. 2013, 47, 7131-7142. [CrossRef]

82. Ramseier, M.K.; von Gunten, U.; Freihofer, P.; Hammes, F. Kinetics of membrane damage to high (HNA) and low (LNA) nucleic acid bacterial clusters in drinking water by ozone, chlorine, chlorine dioxide, monochloramine, ferrate(VI), and permanganate. Water Res. 2011, 45, 1490-1500. [CrossRef]

83. Zacharias, N.; Kistemann, T.; Schreiber, C. Application of flow cytometry and PMA-qPCR to distinguish between membrane intact and membrane compromised bacteria cells in an aquatic milieu. Int. J. Hyg. Environ. Health 2015, 218, 714-722. [CrossRef]

84. Liang, X.; Soupir, M.L.; Rigby, S.; Jarboe, L.R.; Zhang, W. Flow cytometry is a promising and rapid method for differentiating between freely suspended Escherichia coli and E. coli attached to clay particles. J. Appl. Microbiol. 2014, 117, 1730-1739. [CrossRef]

85. Ma, L.L.; Mao, G.N.; Liu, J.; Yu, H.; Gao, G.H.; Wang, Y.Y. Rapid quantification of bacteria and viruses in influent, settled water, activated sludge and effluent from a wastewater treatment plant using flow cytometry. Water Sci. Technol. 2013, 68, 1763-1769. [CrossRef]

86. Delanoë, A.; Guillamin, M.; Heutte, N.; Gente, S.; Séguin, V.; Garon, D. Interest of the qPCR method calibrated with flow cytometry to quantify Aspergillus versicolor in mold-damaged homes and comparison with the cultural approach. Atmospheric Pollut. Res. 2018, 9, 871-876. [CrossRef]

87. SLMB. Determining the total cell count and ratios of high and low nucleic acid content cells in freshwater using flow cytometry. Vol. Swiss Food Book 2012, 67, 1636-1645. [CrossRef]

88. Afari, G.K.; Hung, Y.C. Detection and verification of the viable but nonculturable (VBNC) state of Escherichia coli O157: H7 and Listeria monocytogenes using flow cytometry and standard plating. J. Food Sci. 2018, 83, 1913-1920. [CrossRef]

89. Massicotte, R.; Mafu, A.A.; Ahmad, D.; Deshaies, F.; Pichette, G.; Belhumeur, P. Comparison between flow cytometry and traditional culture methods for efficacy assessment of six disinfectant agents against nosocomial bacterial species. Front. Microbiol. 2017, 8, 112. [CrossRef]

90. Prest, E.I.; Weissbrodt, D.G.; Hammes, F.; van Loosdrecht, M.C.M.; Vrouwenvelder, J.S. Long-term bacterial dynamics in a full-scale drinking water distribution system. PLoS ONE 2016, 11, e0164445. [CrossRef]

91. Berney, M.; Hammes, F.; Bosshard, F.; Weilenmann, H.U.; Egli, T. Assessment and interpretation of bacterial viability by using the LIVE/DEAD BacLight Kit in combination with flow cytometry. Appl. Environ. Microbiol. 2007, 73, 3283-3290. [CrossRef]

92. Hammes, F.; Broger, T.; Weilenmann, H.-U.; Vital, M.; Helbing, J.; Bosshart, U.; Huber, P.; Peter Odermatt, R.; Sonnleitner, B. Development and laboratory-scale testing of a fully automated online flow cytometer for drinking water analysis. Cytom. Part $A$ 2012, 81, 508-516. [CrossRef] [PubMed]

93. Proctor, C.R.; Besmer, M.D.; Langenegger, T.; Beck, K.; Walser, J.-C.; Ackermann, M.; Bürgmann, H.; Hammes, F. Phylogenetic clustering of small low nucleic acid-content bacteria across diverse freshwater ecosystems. ISME J. 2018, 12, 1344-1359. [CrossRef]

94. Bray, J.R.; Curtis, J.T. An ordination of the upland forest communities of Southern Wisconsin. Ecol. Monogr. 1957, 27, 325-349. [CrossRef]

95. Greenacre, M.; Primicerio, R. Measures of distance between samples: Noneuclidean. In Multivariate Analysis of Ecological Data; Fundación BBVA: Bilbao, Spain, 2014.

96. DeLong, E.F.; Wickham, G.S.; Pace, N.R. Phylogenetic stains: Ribosomal RNA-based probes for the identification of single cells. Science 1989, 243, 1360-1363. [CrossRef] [PubMed]

97. Amann, R.I.; Binder, B.J.; Olson, R.J.; Chisholm, S.W.; Devereux, R.; Stahl, D.A. Combination of 16S ribosomal-RNA-targeted oligonucleotide probes with flow-cytometry for analyzing mixed microbial-populations. Appl. Environ. Microbiol. 1990, 56, 1919-1925. [CrossRef] [PubMed]

98. Oliveira, R.; Almeida, C.; Azevedo, N.F. Detection of microorganisms by fluorescence in situ hybridization using peptide nucleic acid. In Peptide Nucleic Acids: Methods and Protocols; Nielsen, P.E., Ed.; Springer: New York, NY, USA, 2020; pp. 217-230. [CrossRef]

99. Wagner, M.; Haider, S. New trends in fluorescence in situ hybridization for identification and functional analyses of microbes. Curr. Opin. Biotechnol. 2012, 23, 96-102. [CrossRef] [PubMed]

100. Amann, R.; Fuchs, B.M.; Behrens, S. The identification of microorganisms by fluorescence in situ hybridisation. Curr. Opin. Biotechnol. 2001, 12, 231-236. [CrossRef]

101. Amann, R.; Fuchs, B.M. Single-cell identification in microbial communities by improved fluorescence in situ hybridization techniques. Nat. Rev. Microbiol. 2008, 6, 339-348. [CrossRef]

102. Amann, R.I.; Ludwig, W.; Schleifer, K.H. Phylogenetic identification and in-situ detection of individual microbial-cells without cultivation. Microbiol. Rev. 1995, 59, 143-169. [CrossRef]

103. Bokulich, N.A.; Mills, D.A. Next-generation approaches to the microbial ecology of food fermentations. BMB Rep. 2012, 45, 377-389. [CrossRef]

104. Amann, R.I.; Krumholz, L.; Stahl, D.A. Fluorescent-oligonucleotide probing of whole cells for determinative, phylogenetic, and environmental studies in microbiology. J. Bacteriol. 1990, 172, 762-770. [CrossRef]

105. Gunasekera, T.S.; Veal, D.A.; Attfield, P.V. Potential for broad applications of flow cytometry and fluorescence techniques in microbiological and somatic cell analyses of milk. Int. J. Food Microbiol. 2003, 85, 269-279. [CrossRef] 
106. Zwirglmaier, K. Fluorescence in situ hybridisation (FISH)-The next generation. FEMS Microbiol. Lett. 2005, 246, 151-158. [CrossRef]

107. Moter, A.; Göbel, U.B. Fluorescence in situ hybridization (FISH) for direct visualization of microorganisms. J. Microbiol. Methods 2000, 41, 85-112. [CrossRef]

108. Bottari, B.; Ercolini, D.; Gatti, M.; Neviani, E. Application of FISH technology for microbiological analysis: Current state and prospects. Appl. Microbiol. Biotechnol. 2006, 73, 485-494. [CrossRef]

109. Cerqueira, L.; Azevedo, N.F.; Almeida, C.; Jardim, T.; Keevil, C.W.; Vieira, M.J. DNA mimics for the rapid identification of microorganisms by fluorescence in situ hybridization (FISH). Int. J. Mol. Sci. 2008, 9, 1944-1960. [CrossRef]

110. Schönhuber, W.; Fuchs, B.; Juretschko, S.; Amann, R. Improved sensitivity of whole-cell hybridization by the combination of horseradish peroxidase-labeled oligonucleotides and tyramide signal amplification. Appl. Environ. Microbiol. 1997, 63, 3268-3273. [CrossRef]

111. DeLong, E.F.; Taylor, L.T.; Marsh, T.L.; Preston, C.M. Visualization and enumeration of marine planktonic archaea and bacteria by using polyribonucleotide probes and fluorescent in situ hybridization. Appl. Environ. Microbiol. 1999, 65, 5554-5563. [CrossRef] [PubMed]

112. Wagner, M.; Schmid, M.; Juretschko, S.; Trebesius, K.-H.; Bubert, A.; Goebel, W.; Schleifer, K.-H. In situ detection of a virulence factor mRNA and 16S rRNA in Listeria monocytogenes. FEMS Microbiol. Lett. 1998, 160, 159-168. [CrossRef] [PubMed]

113. Bisha, B.; Brehm-Stecher, B.F. Simple adhesive-tape-based sampling of tomato surfaces combined with rapid fluorescence in situ hybridization for Salmonella detection. Appl. Environ. Microbiol. 2009, 75, 1450-1455. [CrossRef]

114. Ercolini, D.; Villani, F.; Aponte, M.; Mauriello, G. Fluorescence in situ hybridisation detection of Lactobacillus plantarum group on olives to be used in natural fermentations. Int. J. Food Microbiol 2006, 112, 291-296. [CrossRef]

115. Bisha, B.; Brehm-Stecher, B.F. Flow-through imaging cytometry for characterization of Salmonella subpopulations in alfalfa sprouts, a complex food system. Biotechnol. J. 2009, 4, 880-887. [CrossRef]

116. Vieira-Pinto, M.; Oliveira, M.; Aranha, J.; Martins, C.; Bernardo, F. Influence of an enrichment step on Salmonella sp. detection by fluorescent in situ hybridization on pork samples. Food Control 2008, 19, 286-290. [CrossRef]

117. Oliveira, M.; Vieira-Pinto, M.; Martins da Costa, P.; Vilela, C.L.; Martins, C.; Bernardo, F. Occurrence of Salmonella spp. in samples from pigs slaughtered for consumption: A comparison between ISO 6579:2002 and 23S rRNA fluorescent in situ hybridization method. Food Res. Int. 2012, 45, 984-988. [CrossRef]

118. Rohde, A.; Hammerl, J.A.; Appel, B.; Dieckmann, R.; Al Dahouk, S. Differential detection of pathogenic Yersinia spp. by fluorescence in situ hybridization. Food Microbiol. 2017, 62, 39-45. [CrossRef]

119. Rathnayaka, R.M.U.S.K. Effect of sample pre-enrichment and characters of food samples on the examination for the Salmonella by plate count method and fluorescent in-situ hybridization technique. Am. J. Food Technol. 2011, 6, 851-856. [CrossRef]

120. Rocha, R.; Sousa, J.M.; Cerqueira, L.; Vieira, M.J.; Almeida, C.; Azevedo, N.F. Development and application of peptide nucleic acid fluorescence in situ hybridization for the specific detection of Listeria monocytogenes. Food Microbiol. 2019, 80, 1-8. [CrossRef]

121. Shimizu, S.; Ootsubo, M.; Kubosawa, Y.; Fuchizawa, I.; Kawai, Y.; Yamazaki, K. Fluorescent in situ hybridization in combination with filter cultivation (FISHFC) method for specific detection and enumeration of viable Clostridium perfringens. Food Microbiol. 2009, 26, 425-431. [CrossRef]

122. Moreno, Y.; Hernández, M.; Ferrús, M.A.; Alonso, J.L.; Botella, S.; Montes, R.; Hernández, J. Direct detection of thermotolerant campylobacters in chicken products by PCR and in situ hybridization. Res. Microbiol. 2001, 152, 577-582. [CrossRef]

123. Salimi, G.; Mousavi, Z.E.; Kiani, H. Efficiency of fluorescence in situ hybridization (FISH) method for the rapid detection of Salmonella in minced lamb meat: Method analysis and optimization. J. Microbiol. Methods 2020, 175, 105989. [CrossRef] [PubMed]

124. Fang, Q.; Brockmann, S.; Botzenhart, K.; Wiedemann, A. Improved detection of Salmonella spp. in foods by fluorescent in situ hybridization with 23S rRNA probes: A comparison with conventional culture methods. J. Food Prot. 2003, 66, 723-731. [CrossRef]

125. Cocolin, L.; Diez, A.; Urso, R.; Rantsiou, K.; Comi, G.; Bergmaier, I.; Beimfohr, C. Optimization of conditions for profiling bacterial populations in food by culture-independent methods. Int. J. Food Microbiol. 2007, 120, 100-109. [CrossRef] [PubMed]

126. Fuchizawa, I.; Shimizu, S.; Kawai, Y.; Yamazaki, K. Specific detection and quantitative enumeration of Listeria spp. using fluorescent in situ hybridization in combination with filter cultivation (FISHFC). J. Appl. Microbiol. 2008, 105, 502-509. [CrossRef] [PubMed]

127. Fuchizawa, I.; Shimizu, S.; Ootsubo, M.; Kawai, Y.; Yamazaki, K. Specific and rapid quantification of viable Listeria monocytogenes using fluorescence in situ hybridization in combination with filter cultivation. Microbes Environ. 2009, 24, 273-275. [CrossRef]

128. Ootsubo, M.; Shimizu, T.; Tanaka, R.; Sawabe, T.; Tajima, K.; Ezura, Y. Seven-hour fluorescence in situ hybridization technique for enumeration of Enterobacteriaceae in food and environmental water sample. J. Appl. Microbiol. 2003, 95, 1182-1190. [CrossRef] [PubMed]

129. Graczyk, T.K.; Conn, D.B.; Lucy, F.; Minchin, D.; Tamang, L.; Moura, L.N.S.; DaSilva, A.J. Human waterborne parasites in zebra mussels (Dreissena polymorpha) from the Shannon River drainage area, Ireland. Parasitol. Res. 2004, 93, 385-391. [CrossRef] [PubMed]

130. Ercolini, D.; Hill, P.J.; Dodd, C.E.R. Development of a fluorescence in situ hybridization method for cheese using a $16 \mathrm{~S}$ rRNA probe. J. Microbiol. Methods 2003, 52, 267-271. [CrossRef]

131. Mounier, J.; Monnet, C.; Jacques, N.; Antoinette, A.; Irlinger, F. Assessment of the microbial diversity at the surface of Livarot cheese using culture-dependent and independent approaches. Int. J. Food Microbiol. 2009, 133, 31-37. [CrossRef] 
132. Kollöffel, B.; Meile, L.; Teuber, M. Analysis of brevibacteria on the surface of Gruyère cheese detected by in situ hybridization and by colony hybridization. Lett. Appl. Microbiol. 1999, 29, 317-322. [CrossRef]

133. Babot, J.D.; Hidalgo, M.; Argañaraz-Martínez, E.; Apella, M.C.; Perez Chaia, A. Fluorescence in situ hybridization for detection of classical propionibacteria with specific $16 \mathrm{~S}$ rRNA-targeted probes and its application to enumeration in Gruyère cheese. Int. J. Food Microbiol. 2011, 145, 221-228. [CrossRef] [PubMed]

134. Fornasari, M.E.; Rossetti, L.; Remagni, C.; Giraffa, G. Quantification of Enterococcus italicus in traditional Italian cheeses by fluorescence whole-cell hybridization. Syst. Appl. Microbiol. 2008, 31, 223-230. [CrossRef]

135. Almeida, C.; Cerqueira, L.; Azevedo, N.F.; Vieira, M.J. Detection of Salmonella enterica serovar Enteritidis using real time PCR, immunocapture assay, PNA FISH and standard culture methods in different types of food samples. Int. J. Food Microbiol. 2013, 161, 16-22. [CrossRef]

136. Almeida, C.; Sousa, J.M.; Rocha, R.; Cerqueira, L.; Fanning, S.; Azevedo, N.F.; Vieira, M.J. Detection of Escherichia coli O157 by peptide nucleic acid fluorescence in situ hybridization (PNA-FISH) and comparison to a standard culture method. Appl. Environ. Microbiol. 2013, 79, 6293-6300. [CrossRef]

137. Zhang, X.; Wu, S.; Li, K.; Shuai, J.; Dong, Q.; Fang, W. Peptide nucleic acid fluorescence in situ hybridization for identification of Listeria genus, Listeria monocytogenes and Listeria ivanovii. Int. J. Food Microbiol. 2012, 157, 309-313. [CrossRef]

138. Almeidaa, C.; Azevedo, N.F.; Fernandes, R.M.; Keevil, C.W.; Vieira, M.J. Fluorescence in situ hybridization method using a peptide nucleic acid probe for identification of Salmonella spp. in a broad spectrum of samples. Appl. Environ. Microbiol. 2010, 76, 4476-4485. [CrossRef] [PubMed]

139. Bottari, B.; Santarelli, M.; Neviani, E.; Gatti, M. Natural whey starter for Parmigiano Reggiano: Culture-independent approach. J. Appl. Microbiol. 2010, 108, 1676-1684. [CrossRef]

140. Friedrich, U.; Lenke, J. Improved enumeration of lactic acid bacteria in mesophilic dairy starter cultures by using multiplex quantitative real-time PCR and flow cytometry-fluorescence in situ hybridization. Appl. Environ. Microbiol. 2006, 72, $4163-4171$. [CrossRef] [PubMed]

141. Olsen, K.N.; Brockmann, E.; Molin, S. Quantification of Leuconostoc populations in mixed dairy starter cultures using fluorescence in situ hybridization. J. Appl. Microbiol. 2007, 103, 855-863. [CrossRef]

142. Yamaguchi, N.; Kitaguchi, A.; Nasu, M. Selective enumeration of viable Enterobacteriaceae and Pseudomonas spp. in milk within $7 \mathrm{~h}$ by multicolor fluorescence in situ hybridization following microcolony formation. J. Biosci. Bioeng. 2012, 113, 746-750. [CrossRef]

143. Angelidis, A.S.; Tirodimos, I.; Bobos, M.; Kalamaki, M.S.; Papageorgiou, D.K.; Arvanitidou, M. Detection of Helicobacter pylori in raw bovine milk by fluorescence in situ hybridization (FISH). Int. J. Food Microbiol. 2011, 151, 252-256. [CrossRef] [PubMed]

144. Laflamme, C.; Gendron, L.; Turgeon, N.; Filion, G.; Ho, J.; Duchaine, C. Rapid detection of germinating Bacillus cereus cells using fluorescent in situ hybridization. J. Rapid Methods Autom. Microbiol. 2009, 17, 80-102. [CrossRef]

145. Gunasekera, T.S.; Dorsch, M.R.; Slade, M.B.; Veal, D.A. Specific detection of Pseudomonas spp. in milk by fluorescence in situ hybridization using ribosomal RNA directed probes. J. Appl. Microbiol. 2003, 94, 936-945. [CrossRef] [PubMed]

146. Machado, A.; Almeida, C.; Carvalho, A.; Boyen, F.; Haesebrouck, F.; Rodrigues, L.; Cerca, N.; Azevedo, N.F. Fluorescence in situ hybridization method using a peptide nucleic acid probe for identification of Lactobacillus spp. in milk samples. Int. J. Food Microbiol. 2013, 162, 64-70. [CrossRef]

147. Mikš-Krajnik, M.; Babuchowski, A. 16S rRNA-targeted oligonucleotide probes for direct detection of Propionibacterium freudenreichii in presence of Lactococcus lactis with multicolour fluorescence in situ hybridization. Lett. Appl. Microbiol. 2014, 59, 320-327. [CrossRef] [PubMed]

148. Kitaguchi, A.; Yamaguchi, N.; Nasu, M. Enumeration of respiring Pseudomonas spp. in milk within 6 hours by fluorescence in situ hybridization following formazan reduction. Appl. Environ. Microbiol. 2005, 71, 2748-2752. [CrossRef] [PubMed]

149. Stender, H.; Kurtzman, C.; Hyldig-Nielsen, J.J.; Sørensen, D.; Broomer, A.; Oliveira, K.; Perry, O.; Keefe, H.; Sage, A.; Young, B.; et al. Identification of Dekkera bruxellensis (Brettanomyces) from wine by fluorescence in situ hybridization using peptide nucleic acid probes. Appl. Environ. Microbiol. 2001, 67, 938. [CrossRef]

150. Blasco, L.a.; Ferrer, S.; Pardo, I. Development of specific fluorescent oligonucleotide probes for in situ identification of wine lactic acid bacteria. FEMS Microbiol. Lett. 2003, 225, 115-123. [CrossRef]

151. Xufre, A.; Albergaria, H.; Inácio, J.; Spencer-Martins, I.; Gírio, F. Application of fluorescence in situ hybridisation (FISH) to the analysis of yeast population dynamics in winery and laboratory grape must fermentations. Int. J. Food Microbiol. 2006, 108, 376-384. [CrossRef]

152. Andorra, I.; Monteiro, M.; Esteve-Zarzoso, B.; Albergaria, H.; Mas, A. Analysis and direct quantification of Saccharomyces cerevisiae and Hanseniaspora guilliermondii populations during alcoholic fermentation by fluorescence in situ hybridization, flow cytometry and quantitative PCR. Food Microbiol. 2011, 28, 1483-1491. [CrossRef] [PubMed]

153. Wang, C.; Esteve-Zarzoso, B.; Mas, A. Monitoring of Saccharomyces cerevisiae, Hanseniaspora uvarum, and Starmerella bacillaris (synonym Candida zemplinina) populations during alcoholic fermentation by fluorescence in situ hybridization. Int. J. Food Microbiol. 2014, 191, 1-9. [CrossRef]

154. Branco, P.; Monteiro, M.; Moura, P.; Albergaria, H. Survival rate of wine-related yeasts during alcoholic fermentation assessed by direct live/dead staining combined with fluorescence in situ hybridization. Int. J. Food Microbiol. 2012, 158, 49-57. [CrossRef] 
155. Branco, P.; Candeias, A.; Caldeira, A.T.; González-Pérez, M. A simple procedure for detecting Dekkera bruxellensis in wine environment by RNA-FISH using a novel probe. Int. J. Food Microbiol. 2020, 314, 108415. [CrossRef]

156. Yasuhara, T.; Yuuki, T.; Kagami, N. Novel quantitative method for detection of pectinatus using rRNA targeted fluorescent probes. J. Am. Soc. Brew. Chem. 2001, 59, 117-121. [CrossRef]

157. Trček, J.; Lipoglavšek, L.; Avguštin, G. $16 \mathrm{~S}$ rRNA in situ hybridization followed by flow cytometry for rapid identification of acetic acid bacteria involved in submerged industrial vinegar production. Food Technol. Biotechnol. 2016, 54, 108-112. [CrossRef] [PubMed]

158. Almeida, C.; Azevedo, N.F.; Santos, S.; Keevil, C.W.; Vieira, M.J. Correction: Discriminating multi-species populations in biofilms with peptide nucleic acid fluorescence in situ hybridization (PNA FISH). PLoS ONE 2013, 8, e14786. [CrossRef]

159. Bragança, S.M.; Azevedo, N.F.; Simões, L.C.; Keevil, C.W.; Vieira, M.J. Use of fluorescent in situ hybridisation for the visualisation of Helicobacter pylori in real drinking water biofilms. Water Sci. Technol. 2007, 55, 387-393. [CrossRef] [PubMed]

160. Timke, M.; Wolking, D.; Wang-Lieu, N.Q.; Altendorf, K.; Lipski, A. Microbial composition of biofilms in a brewery investigated by fatty acid analysis, fluorescence in situ hybridisation and isolation techniques. Appl. Microbiol. Biotechnol. 2004, 66, 100-107. [CrossRef] [PubMed]

161. Šilhová, L.; Mot'ková, P.; Šilha, D.; Vytřasová, J. FISH detection of Campylobacter and Arcobacter adhered to stainless steel coupons. J. Microbiol. Biotechnol. Food Sci. 2015, 4, 347-351. [CrossRef]

162. Bottari, B.; Mancini, A.; Ercolini, D.; Gatti, M.; Neviani, E. FISHing for food microorganisms. In Fluorescence In Situ Hybridization (FISH): Application Guide; Liehr, T., Ed.; Springer: Berlin/Heidelberg, Germany, 2017; pp. 511-530. [CrossRef]

163. Yamaguchi, N.; Goto, S. Rapid quantification of Escherichia coli in potable water by fluorescence in situ hybridization performed in liquid (liq-FISH) and a microfluidic system. Water Air Soil Pollut. 2019, 230, 285. [CrossRef]

164. Lehtola, M.J.; Loades, C.J.; Keevil, C.W. Advantages of peptide nucleic acid oligonucleotides for sensitive site directed 16S rRNA fluorescence in situ hybridization (FISH) detection of Campylobacter jejuni, Campylobacter coli and Campylobacter lari. J. Microbiol. Methods 2005, 62, 211-219. [CrossRef]

165. Lehtola, M.J.; Torvinen, E.; Miettinen, I.T.; Keevil, C.W. Fluorescence in situ hybridization using peptide nucleic acid probes for rapid detection of Mycobacterium avium subsp. avium and Mycobacterium avium subsp. paratuberculosis in potable-water biofilms. Appl. Environ. Microbiol. 2006, 72, 848-853. [CrossRef]

166. Brient, L.; Ben Gamra, N.; Periot, M.; Roumagnac, M.; Zeller, P.; Bormans, M.; Méjean, A.; Ploux, O.; Biegala, I.C. Rapid Characterization of Microcystin-Producing Cyanobacteria in Freshwater Lakes by TSA-FISH (Tyramid Signal AmplificationFluorescent In Situ Hybridization). Front. Environ. Sci. 2017, 5, 43. [CrossRef]

167. Gerdts, G.; Luedke, G. FISH and chips: Marine bacterial communities analyzed by flow cytometry based on microfluidics. J. Microbiol. Methods 2006, 64, 232-240. [CrossRef]

168. Glöckner, F.O.; Fuchs, B.M.; Amann, R. Bacterioplankton compositions of lakes and oceans: A first comparison based on fluorescence in situ hybridization. Appl. Environ. Microbiol. 1999, 65, 3721-3726. [CrossRef]

169. Khandeparker, D.L.; Desai, D.; Anil, A.; Sawant, S.; Krishnamurthy, V.; Mapari, K.; Jolkifli, Z.; Karim, N.; Thoha, H.; Hadiyanto, H.; et al. Application of Fluorescence in situ hybridization-Flow cytometry (FISH-FCM) technique to detect and quantify Vibrio cholerae populations from different geographic regions. ASEAN J. Sci. Technol. Dev. 2018, 35, 159-165. [CrossRef]

170. Lee, J.; Katano, T.; Chang, M.; Han, M.S. Application of tyramide signal amplification-fluorescence in situ hybridisation and flow cytometry to detection of Heterosigma akashiwo (Raphidophyceae) in natural waters. N. Z. J. Mar. Freshw. Res. 2012, 46, 137-148. [CrossRef]

171. Manti, A.; Boi, P.; Amalfitano, S.; Puddu, A.; Papa, S. Experimental improvements in combining CARD-FISH and flow cytometry for bacterial cell quantification. J. Microbiol. Methods 2011, 87, 309-315. [CrossRef] [PubMed]

172. Neuenschwander, S.M.; Salcher, M.M.; Pernthaler, J. Fluorescence in situ hybridization and sequential catalyzed reporter deposition (2C-FISH) for the flow cytometric sorting of freshwater ultramicrobacteria. Front. Microbiol. 2015, 6, 247. [CrossRef] [PubMed]

173. Sekar, R.; Fuchs, B.M.; Amann, R.; Pernthaler, J. Flow sorting of marine bacterioplankton after fluorescence in situ hybridization. Appl. Environ. Microbiol. 2004, 70, 6210-6219. [CrossRef] [PubMed]

174. Tang, Y.Z.; Gin, K.Y.H.; Lim, T.H. High-temperature fluorescent in Situ hybridization for detecting Escherichia coli in Seawater samples, using rRNA-targeted oligonucleotide probes and flow cytometry. Appl. Environ. Microbiol. 2005, 71, 8157-8164. [CrossRef]

175. Kristiansen, A.; Saunders, A.M.; Hansen, A.A.; Nielsen, P.H.; Nielsen, J.L. Community structure of bacteria and fungi in aerosols of a pig confinement building. FEMS Microbiol. Ecol. 2012, 80, 390-401. [CrossRef]

176. Chi, M.-C.; Li, C.-S. Fluorochrome and Fluorescent In Situ Hybridization to Monitor Bioaerosols in Swine Buildings. Aerosol Sci. Technol. 2005, 39, 1101-1110. [CrossRef]

177. Neef, A.; Kämpfer, P. Molecular Identification of Airborne Microorganisms from Composting Facilities. In Microbiology of Composting; Springer: Berlin/Heidelberg, Germany, 2002; pp. 585-594.

178. Deloge-Abarkan, M.; Ha, T.-L.; Robine, E.; Zmirou-Navier, D.; Mathieu, L. Detection of airborne Legionella while showering using liquid impingement and fluorescent in situ hybridization (FISH). J. Environ. Monit. 2007, 9, 91-97. [CrossRef]

179. Gunasekera, T.S.; Attfield, P.V.; Veal, D.A. A flow cytometry method for rapid detection and enumeration of total bacteria in milk. Appl. Environ. Microbiol. 2000, 66, 1228-1232. [CrossRef] [PubMed] 
180. Gasol, J.M.; Del Giorgio, P.A. Using flow cytometry for counting natural planktonic bacteria and understanding the structure of planktonic bacterial communities. Sci. Mar. 2000, 64, 197-224. [CrossRef]

181. Ou, F.; McGoverin, C.; Swift, S.; Vanholsbeeck, F. Absolute bacterial cell enumeration using flow cytometry. J. Appl. Microbiol. 2017, 123, 464-477. [CrossRef] [PubMed]

182. Stiefel, P.; Schmidt-Emrich, S.; Maniura-Weber, K.; Ren, Q. Critical aspects of using bacterial cell viability assays with the fluorophores SYTO9 and propidium iodide. BMC Microbiol. 2015, 15, 36. [CrossRef] [PubMed]

183. Rosenberg, M.; Azevedo, N.F.; Ivask, A. Propidium iodide staining underestimates viability of adherent bacterial cells. Sci. Rep. 2019, 9, 6483. [CrossRef]

184. Sayas, E.; García-López, F.; Serrano, R. Toxicity, mutagenicity and transport in Saccharomyces cerevisiae of three popular DNA intercalating fluorescent dyes. Yeast 2015, 32, 595-606. [CrossRef]

185. Lin, F.; Li, C.; Chen, Z. Exopolysaccharide-derived carbon dots for microbial viability assessment. Front. Microbiol. 2018, 9, 2697. [CrossRef]

186. Haines, A.M.; Tobe, S.S.; Kobus, H.J.; Linacre, A. Properties of nucleic acid staining dyes used in gel electrophoresis. Electrophoresis 2015, 36, 941-944. [CrossRef]

187. Vujanovic, S.; Goh, Y.K.; Vujanovic, V. Natural fruit extracts as non-toxic fluorescent dyes for staining fungal chlamydospores. World J. Microbiol. Biotechnol. 2012, 28, 387-390. [CrossRef]

188. Kurutos, A.; Ilic-Tomic, T.; Kamounah, F.S.; Vasilev, A.A.; Nikodinovic-Runic, J. Non-cytotoxic photostable monomethine cyanine platforms: Combined paradigm of nucleic acid staining and in vivo imaging. J. Photochem. Photobiol. A Chem. 2020, 397, 112598. [CrossRef]

189. Volpi, E.V. Formamide-free fluorescence in situ hybridization (FISH). In Fluorescence In Situ Hybridization (FISH): Application Guide; Liehr, T., Ed.; Springer: Berlin/Heidelberg, Germany, 2017; pp. 135-139.

190. Adeyemo, S.; Akinloye, A.; Adekanmi, G. The use of plant dyes for microbial staining and identification: An eco-friendly and non-toxic alternative method. J. Adv. Biol. Biotechnol. 2018, 16, 1-10. [CrossRef]

191. Ommen, P.; Zobek, N.; Meyer, R.L. Quantification of biofilm biomass by staining: Non-toxic safranin can replace the popular crystal violet. J. Microbiol. Methods 2017, 141, 87-89. [CrossRef]

192. Jasson, V.; Jacxsens, L.; Luning, P.; Rajkovic, A.; Uyttendaele, M. Alternative microbial methods: An overview and selection criteria. Food Microbiol. 2010, 27, 710-730. [CrossRef] [PubMed]

193. Bunthof, C.J. Flow Cytometry, Fluorescent Probes, and Flashing Bacteria; Wageningen University: Wageningen, The Netherlands, 2002.

194. Wilkinson, M.G. Flow cytometry in food microbiology: Challenges, opportunities and progress to date. Tec. Lab. 2016, 417, 722-728.

195. Boulanger, C.A.; Edelstein, P.H. Precision and accuracy of recovery of Legionella pneumophila from seeded tap water by filtration and centrifugation. Appl. Environ. Microbiol. 1995, 61, 1805-1809. [CrossRef]

196. Chen, P.-S.; Li, C.-S. Real-time monitoring for bioaerosols-Flow cytometry. Analyst 2007, 132, 14-16. [CrossRef]

197. Yoo, K.; Lee, T.K.; Choi, E.; Yang, J.; Shukla, S.; Hwang, S.-I.; Park, J. Approach of molecular methods for the detection and monitoring of microbial communities in bioaerosols: A review. J. Environ. Sci. 2016, 51, 234-247. [CrossRef]

198. Liesche, J.; Marek, M.; Günther-Pomorski, T. Cell wall staining with Trypan blue enables quantitative analysis of morphological changes in yeast cells. Front. Microbiol. 2015, 6, 107. [CrossRef]

199. Zhu, X.; Shi, H.; Shen, Y.; Zhang, B.; Zhao, J.; Li, G. A green method of staining DNA in polyacrylamide gel electrophoresis based on fluorescent copper nanoclusters synthesized in situ. Nano Res. 2015, 8, 2714-2720. [CrossRef]

200. Chiaraviglio, L.; Kirby, J.E. Evaluation of impermeant, DNA-binding dye fluorescence as a real-time readout of eukaryotic cell toxicity in a high throughput screening format. ASSAY Drug Dev. Technol. 2014, 12, 219-228. [CrossRef]

201. Tashyreva, D.; Elster, J.; Billi, D. A novel staining protocol for multiparameter assessment of cell heterogeneity in Phormidium populations (Cyanobacteria) employing fluorescent dyes. PLoS ONE 2013, 8, e55283. [CrossRef] [PubMed]

202. Kotenkova, E.; Bataeva, D.; Minaev, M.; Zaiko, E. Application of EvaGreen for the assessment of Listeria monocytogenes ATCC 13932 cell viability using flow cytometry. AIMS Microbiol. 2019, 5, 39-47. [CrossRef]

203. Matthiesen, S.H.; Hansen, C.M. Fast and non-toxic in situ hybridization without blocking of repetitive sequences. PLoS ONE 2012, 7, e40675. [CrossRef] [PubMed]

204. Kalinka, A.; Myśliwy, M.; Achrem, M. Comparison of ethylene carbonate and formamide as components of the hybridization mixture in FISH. Sci. Agric. 2021, 78, e20190315. [CrossRef]

205. Golczyk, H. A simple non-toxic ethylene carbonate fluorescence in situ hybridization (EC-FISH) for simultaneous detection of repetitive DNA sequences and fluorescent bands in plants. Protoplasma 2019, 256, 873-880. [CrossRef]

206. Sinigaglia, C.; Thiel, D.; Hejnol, A.; Houliston, E.; Leclere, L. A safer, urea-based in situ hybridization method improves detection of gene expression in diverse animal species. bioRxiv 2018, 434, 15-23. [CrossRef] [PubMed]

207. Aistleitner, K.; Sieper, T.; Stürz, I.; Jeske, R.; Tritscheller, S.; Mantel, S.; Tscherne, A.; Zange, S.; Stoecker, K.; Wölfel, R. NOTIFy (non-toxic lyophilized field)-FISH for the identification of biological agents by fluorescence in situ hybridization. PLoS ONE 2020, 15, e0230057. [CrossRef]

208. Camp, J.E.; Nyamini, S.B.; Scott, F.J. Cyrene ${ }^{\mathrm{TM}}$ is a green alternative to DMSO as a solvent for antibacterial drug discovery against ESKAPE pathogens. RSC Med. Chem. 2020, 11, 111-117. [CrossRef] [PubMed] 
209. Yi, X.; Liu, M.; Luo, Q.; Zhuo, H.; Cao, H.; Wang, J.; Han, Y. Toxic effects of dimethyl sulfoxide on red blood cells, platelets, and vascular endothelial cellsin vitro. FEBS Open Biol. 2017, 7, 485-494. [CrossRef] [PubMed]

210. Raso, J. Fundamental and applied aspects of pulsed electric fields for microbial inactivation. In 1st World Congress on Electroporation and Pulsed Electric Fields in Biology, Medicine and Food E Environmental Technologies; Springer: Singapore, 2016; pp. 11-14.

211. Bensalem, S.; Pareau, D.; Cinquin, B.; Français, O.; Le Pioufle, B.; Lopes, F. Impact of pulsed electric fields and mechanical compressions on the permeability and structure of Chlamydomonas reinhardtii cells. Sci. Rep. 2020, 10, 2668. [CrossRef]

212. Novickij, V.; Lastauskienė, E.; Švedienė, J.; Grainys, A.; Staigvila, G.; Paškevičius, A.; Girkontaitè, I.; Zinkevičienè, A.; Markovskaja, S.; Novickij, J. Membrane permeabilization of pathogenic yeast in alternating sub-microsecond electromagnetic fields in combination with conventional electroporation. J. Membr. Biol. 2018, 251, 189-195. [CrossRef]

213. Schottroff, F.; Kastenhofer, J.; Spadiut, O.; Jaeger, H.; Wurm, D.J. Selective release of recombinant periplasmic protein from E. coli using continuous pulsed electric field treatment. Front. Bioeng. Biotechnol. 2020, 8, 1584. [CrossRef]

214. Martínez, J.M.; Delso, C.; Álvarez, I.; Raso, J. Pulsed electric field-assisted extraction of valuable compounds from microorganisms. Compr. Rev. Food Sci. Food Saf. 2020, 19, 530-552. [CrossRef]

215. Zhao, W.; Yang, R.; Shen, X.; Zhang, S.; Chen, X. Lethal and sublethal injury and kinetics of Escherichia coli, Listeria monocytogenes and Staphylococcus aureus in milk by pulsed electric fields. Food Control 2013, 32, 6-12. [CrossRef]

216. Elez-Martínez, P.; Escolà-Hernández, J.; Soliva-Fortuny, R.C.; Martín-Belloso, O. Inactivation of Lactobacillus brevis in orange juice by high-intensity pulsed electric fields. Food Microbiol. 2005, 22, 311-319. [CrossRef]

217. Wouters, P.C.; Bos, A.P.; Ueckert, J. Membrane permeabilization in relation to inactivation kinetics of Lactobacillus species due to pulsed electric fields. Appl. Environ. Microbiol. 2001, 67, 3092-3101. [CrossRef] [PubMed]

218. Vaessen EM, J.; den Besten HM, W.; Patra, T.; van Mossevelde NT, M.; Boom, R.M.; Schutyser MA, I. Pulsed electric field for increasing intracellular trehalose content in Lactiplantibacillus plantarum WCFS1. Innov. Food Sci. Emerg. Technol. 2018, 47, 256-261. [CrossRef]

219. Campana, L.G.; Edhemovic, I.; Soden, D.; Perrone, A.M.; Scarpa, M.; Campanacci, L.; Cemazar, M.; Valpione, S.; Miklavčič, D.; Mocellin, S.; et al. Electrochemotherapy-Emerging applications technical advances, new indications, combined approaches, and multi-institutional collaboration. Eur. J. Surg. Oncol. 2019, 45, 92-102. [CrossRef] [PubMed]

220. Kos, S.; Vanvarenberg, K.; Dolinsek, T.; Cemazar, M.; Jelenc, J.; Préat, V.; Sersa, G.; Vandermeulen, G. Gene electrotransfer into skin using noninvasive multi-electrode array for vaccination and wound healing. Bioelectrochemistry 2017, 114, 33-41. [CrossRef] [PubMed]

221. Vaessen, E.M.J.; Timmermans, R.A.H.; Tempelaars, M.H.; Schutyser, M.A.I.; Den Besten, H.M.W. Reversibility of membrane permeabilization upon pulsed electric field treatment in Lactobacillus plantarum WCFS1. Sci. Rep. 2019, 9, 19990. [CrossRef]

222. Zand, E.; Schottroff, F.; Schoenher, C.; Zimmermann, K.S.; Zunabovic-Pichler, M.; Jaeger, H. An alternative method to describe intermediate cellular states induced by pulsed electric field treatment. Food Control. 2021. submitted.

223. Fröhling, A.; Nettmann, E.; Jäger, H.; Knorr, D.; Schlüter, O. Specific detection of bacteria from food using a combination of PEF and Flow-FISH. In Proceedings of the DGG-Proceedings, Bonn, Germany, 27 February-2 March 2013; pp. 1-5.

224. Ruark-Seward, C.L.; Davis, E.L.; Sit, T.L. Electropermeabilization-based fluorescence in situ hybridization of whole-mount plant parasitic nematode specimens. MethodsX 2019, 6, 2720-2728. [CrossRef] [PubMed]

225. Volpi, E.V.; Bridger, J.M. FISH glossary: An overview of the fluorescence in situ hybridization technique. Biotechniques 2008, 45, 385. [CrossRef]

226. Stoecker, K.; Dorninger, C.; Daims, H.; Wagner, M. Double labeling of oligonucleotide probes for fluorescence in situ hybridization (DOPE-FISH) improves signal intensity and increases rRNA accessibility. Appl. Environ. Microbiol. 2010, 76, 922-926. [CrossRef]

227. Pernthaler, A.; Pernthaler, J.; Amann, R. Fluorescence in situ hybridization and catalyzed reporter deposition for the identification of marine bacteria. Appl. Environ. Microbiol. 2002, 68, 3094-3101. [CrossRef]

228. Schönhuber, W.; Zarda, B.; Eix, S.; Rippka, R.; Herdman, M.; Ludwig, W.; Amann, R. In situ identification of Cyanobacteria with horseradish peroxidase-labeled, rRNA-targeted oligonucleotide probes. Appl. Environ. Microbiol. 1999, 65, 1259-1267. [CrossRef]

229. Grieb, A.; Bowers, R.M.; Oggerin, M.; Goudeau, D.; Lee, J.; Malmstrom, R.R.; Woyke, T.; Fuchs, B.M. A pipeline for targeted metagenomics of environmental bacteria. Microbiome 2020, 8, 21. [CrossRef]

230. Takahashi, H.; Horio, K.; Kato, S.; Kobori, T.; Watanabe, K.; Aki, T.; Nakashimada, Y.; Okamura, Y. Direct detection of mRNA expression in microbial cells by fluorescence in situ hybridization using RNase H-assisted rolling circle amplification. Sci. Rep. 2020, 10, 9588. [CrossRef] [PubMed]

231. Batani, G.; Bayer, K.; Böge, J.; Hentschel, U.; Thomas, T. Fluorescence in situ hybridization (FISH) and cell sorting of living bacteria. Sci. Rep. 2019, 9, 18618. [CrossRef]

232. Choi, J.; Kang, M.; Jung, J.H. Integrated micro-optofluidic platform for real-time detection of airborne microorganisms. Sci. Rep. 2015, 5, 15983. [CrossRef]

233. Chang, C.W.; Ting, Y.T.; Horng, Y.J. Collection efficiency of liquid-based samplers for fungi in indoor air. Indoor Air 2019, 29, 380-389. [CrossRef] [PubMed]

234. Choi, J.; Hong, S.C.; Kim, W.; Jung, J.H. Highly Enriched, Controllable, Continuous Aerosol Sampling Using Inertial Microfluidics and Its Application to Real-Time Detection of Airborne Bacteria. ACS Sens. 2017, 2, 513-521. [CrossRef] [PubMed] 